OECDpublishing

POLICY CHALLENGES

FOR THE NEXT

50 YEARS

OECD ECONOMIC POLICY PAPER

July 2014 No. 9 


\section{Table of contents}

Key messages 6

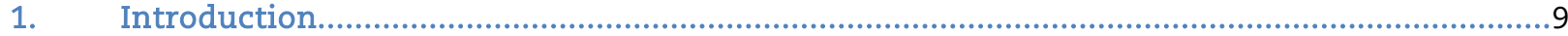

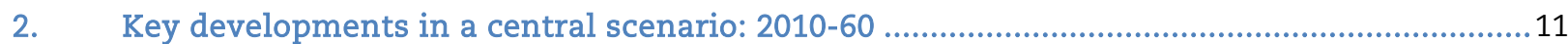

2.1 Global growth is set to slow over the coming fifty years........................................13

2.2 Trade integration is set to grow, implying changes in specialisation even in the absence of further major trade deals.....

2.3 Earning inequalities are likely to continue to rise, reflecting skill-biased technological change and a slower growth in educational attainment ......................18

2.4 Fiscal consolidation will require major efforts in several countries .........................2 21

2.5 Fiscal consolidation and structural reforms are needed to rein in global imbalances

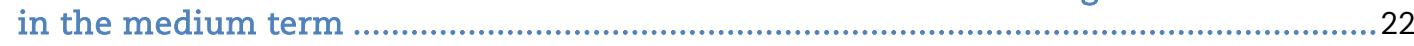

2.6 Tensions and risks for the global outlook until 2060 ..................................... 23

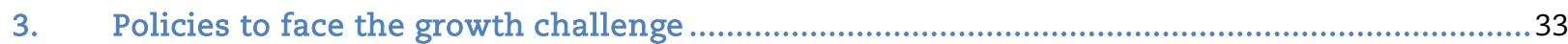

3.1 A more integrated global trading system can boost growth but would increase interdependence and pressures to adjust structural policies .................................. 34

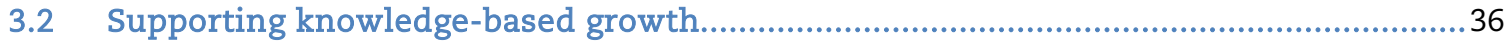

3.3 Labour and education policies have to adjust to changing demographics and rising skill requirements......

3.3. A changing structure of labour demand combined with an ageing labour force will require emphasis on flexibility and matching issues....

4. Policies to deal with rising inequality and pressures on social institutions ........................47

4.1 Policy instruments that can lower earning inequality sometimes harm growth .........47

4.2 Trade-offs between the distribution of household disposable income and growth are often less severe but may grow as international integration proceeds ................. 49

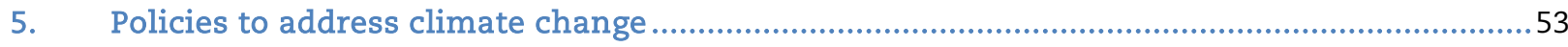

6. Policies to deal with the fiscal challenge ......................................................... 55

6.1 Fiscal challenges could force countries to consolidate through increasingly bad

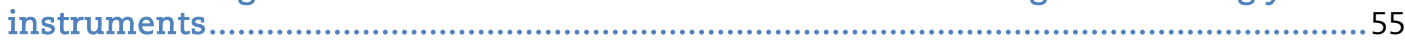

6.2 Structural reforms can mitigate fiscal pressures and help managing risks ...............56

6.3 Rising global integration may reorder the ranking of fiscal instruments over the

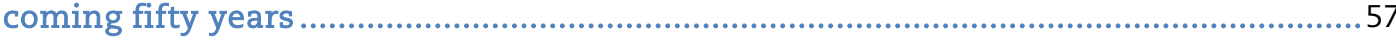

7. Policies for greater macroeconomic stability over the coming fifty years ............................5 57

7.1 Rising trade integration will increase interdependence and could require stronger international coordination on fiscal and structural policies................................. 58

7.2 Polices to handle current account imbalances and mitigate their impact..................60

8. Economic policies for a shifting world .............................................................60

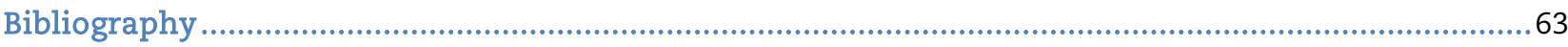




\section{Tables}

Table 1. Impact of structural reforms on growth, earning dispersion and equality in household incomes

Table 2. Assessment of long-term growth and equity effects of fiscal consolidation instruments........ 56

\section{Figures}

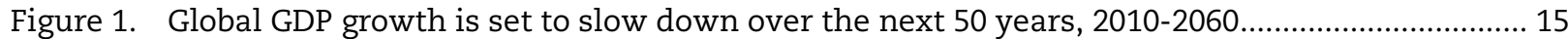

Figure 2. Developments in OECD and non-OECD G20-countries, 1990-2060........................................ 16

Figure 3. Exports as a share of GDP will increase in all regions...................................................... 17

Figure 4. Income inequality has increased in most, but not all OECD countries ................................. 18

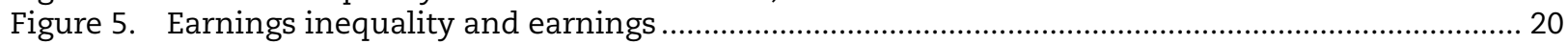

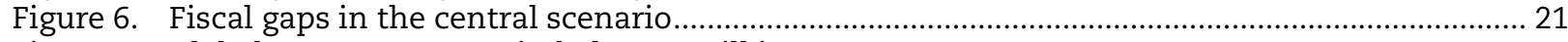

Figure 7. Global current account imbalances will increase ...............................................................22

Figure 8. Increase in demand for tertiary graduations 2009-2060 in central and alternative scenario.... 26

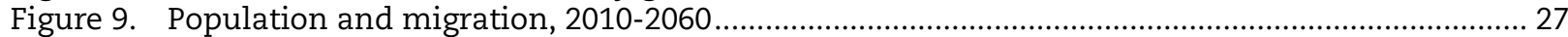

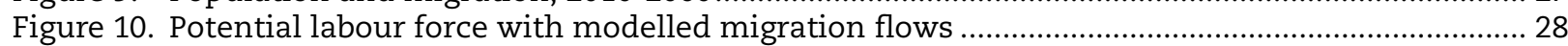

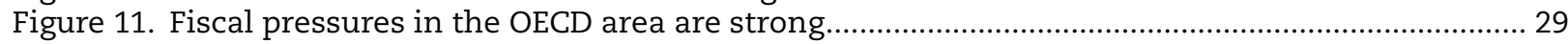

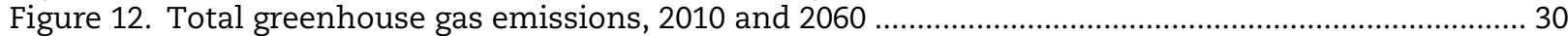

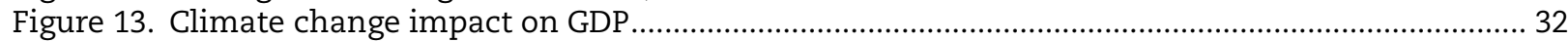

Figure 14. Longevity adjustment of the retirement age increases labour force participation................... 41

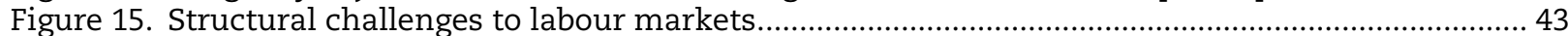

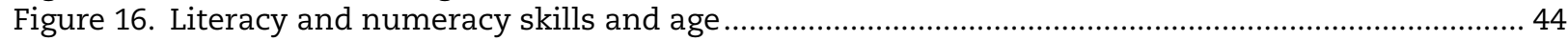

Figure 17. Decrease in earnings inequality if employment protection, union coverage, tax wedges and product market regulation converge to the highest levels in the sample (2060) ....................... 48

Figure 18. Taxes and transfers reduce income dispersion, and more so in...........................................50

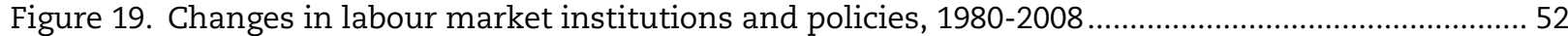

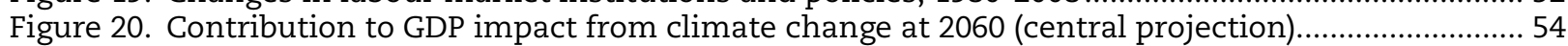

Figure 21. OECD countries will become increasingly exposed to shocks from emerging economies ........ 59

\section{Boxes}

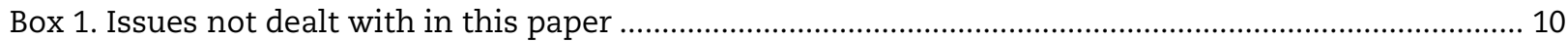

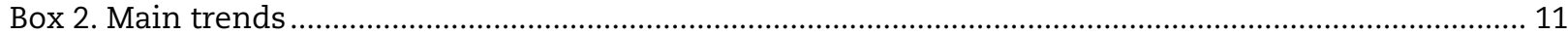

Box 3. The central scenario and its modelling base .......................................................................... 12

Box 4. Using models to identify risks, tensions and consequences of alternative scenarios .....................24

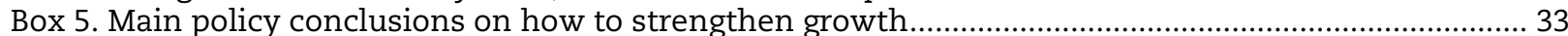

Box 6. The economic impact of further multilateral trade liberalisation ............................................. 35

Box 7. Enabling factors impact on growth........................................................................................ 39

Box 8. Main policy conclusions on dealing with inequality and pressures on social institutions ............. 47

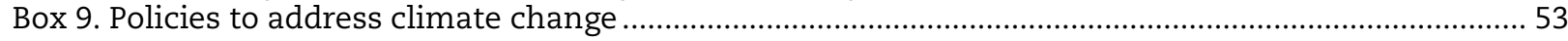

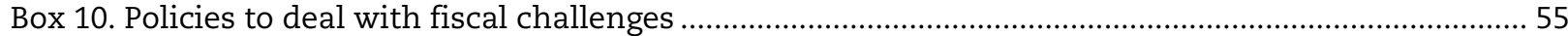

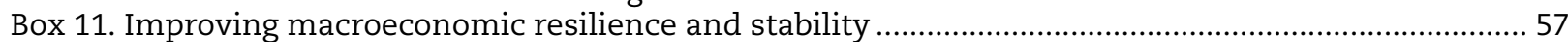




\title{
Policy Challenges for the Next 50 Years
}

This paper has been prepared by:

\author{
Henrik Braconier \\ Giuseppe Nicoletti \\ Ben Westmore
}

Authorised for publication by Jean-Luc Schneider, Deputy Director, Policy Studies Branch, Economics Department 
The OECD EConomic Policy Paper Series is published on the responsibility of the Secretary-General of the OECD. The opinions expressed and the arguments employed herein do not necessarily reflect the official views of OECD member countries.

This paper was written by Henrik Braconier, Giuseppe Nicoletti and Ben Westmore.

An earlier version of this paper was discussed at the Working Party No. 1 of the OECD Economic Policy Committee and at the OECD Economic Policy Committee. The authors would like to thank the participants.

This paper is a synthesis of work conducted at the OECD Economics Department in the context of the OECD@100 project aimed at devising scenarios for the global economy at the 2060 horizon, when the OECD will celebrate its 100th anniversary. The full set of studies on which it is based is listed below and can be found online at http://www.oecd.org/economy/lookingto2060.htm:

Andrews. D and B. Westmore (2014), "Managerial capital and business R\&D as enablers of productivity convergence", OECD Economics Department Working Papers, No. 1137, OECD Publishing, Paris.

Braconier, H. (2014), "Determinants of Tertiary Graduations", OECD Economics Department Working Papers, No. 1138, OECD Publishing, Paris.

Braconier, H. and J. Ruiz Valenzuela (2014), "Gross earning inequalities in OECD countries and major nonmember economies: Determinants and future scenarios", OECD Economics Department Working Papers, No. 1139, OECD Publishing, Paris.

Braconier, H. and R. Dellink (2014), "Consequences of Climate Change Damages for Economic Growth - A Dynamic Quantitative Assessment", OECD Economics Department Working Papers, forthcoming, OECD Publishing, Paris.

Chateau, J., L. Fontagné, J. Fouré, A. Johansson and E. Olaberría (2014), "Trade patterns in the 2060 world economy", OECD Economics Department Working Papers, No. 1142, OECD Publishing, Paris.

Johansson A. and E. Olaberría. (2014), "New evidence on the determinants of industrial specialisation", OECD Economics Department Working Papers, No 1112, OECD Publishing, Paris.

Johansson A., P. Kowalski, E. Olaberría and D. Pellegrino (2014) "What explains the volume and composition of trade? Industrial evidence from a panel of countries", OECD Economics Department Working Papers, No 1128, OECD Publishing, Paris.

Johansson, Å. and E. Olaberría (2014), "Long-term Patterns of Specialisation and Trade", OECD EConomics Department Working Papers, forthcoming OECD Publishing, Paris.

Los, B., M. P. Timmer and G. J. De Vries (2014), “The Demand for Skills 1995 - 2008: A Global Supply Chain Perspective", OECD Economics Department Working Papers, No. 1141, OECD Publishing, Paris.

Westmore, B. (2014) “The Influence of Relative Wage Differentials on International Migration", OECD Economics Department Working Papers, No. 1140, OECD Publishing, Paris.

Series: OECD Economic Policy Papers

ISSN 2226583X

This document and any map included herein are without prejudice to the status of or sovereignty over any territory, to the delimitation of international frontiers and boundaries and to the name of any territory, city or area.

The statistical data for Israel are supplied by and under the responsibility of the relevant Israeli authorities. The use of such data by the OECD is without prejudice to the status of the Golan Heights, East Jerusalem and Israeli settlements in the West Bank under the terms of international law.

C OECD 2014

You can copy, download or print OECD content for your own use, and you can include excerpts from OECD publications, databases and multimedia products in your own documents, presentations, blogs, websites and teaching materials, provided that suitable acknowledgment of OECD as source and copyright owner is given. All requests for public or commercial use and translation rights should be submitted to rights@oecd.org. Requests for permission to photocopy portions of this material for public or commercial use shall be addressed directly to the Copyright Clearance Center (CCC) at info@copyright.com or the Centre français d'exploitation du droit de copie (CFC) at contact@cfcopies.com. 


\section{Abstract / Résumé \\ Policy Challenges for the Next 50 years}

This paper identifies and analyses some key challenges that OECD and partner economies may face over the coming 50 years if underlying global trends relating to growth, trade, inequality and environmental pressures prevail. For example, global growth is likely to slow and become increasingly dependent on knowledge and technology, while the economic costs of environmental damages will mount. The rising economic importance of knowledge will tend to raise returns to skills, likely leading to further increases in earning inequalities within countries. While increases in pre-tax earnings do not automatically transform into rising income inequality, the ability of governments to cushion this impact may be limited, as rising trade integration and consequent rising mobility of tax bases combined with substantial fiscal pressures may hamper such efforts. The paper discusses to what extent national structural policies can address these and other interlinked challenges, but also points to the growing need for international coordination and cooperation to deal with these issues over the coming 50 years.

JEL classification codes: F, H, I2, I3, J1, O3, O4, Q5

Keywords:-Global economy, Growth, technological change, inequality, income distribution, immigration, environmental damages, climate change, tertiary education, fiscal consolidation, structural reforms, interdependence, coordination, projections.

\section{Défis politiques pour les 50 prochaines années}

Ce document passe en revue et analyse quelques-uns des problèmes clés auxquels les pays de l'OCDE et leurs partenaires pourraient être confrontés dans les 50 prochaines années si les grandes tendances mondiales se confirment en matière de croissance, d'échanges, d'inégalités et de pressions environnementales. Par exemple, la croissance mondiale va vraisemblablement ralentir et devenir de plus en plus tributaire du savoir et de la technologie. Les coûts économiques des dommages causés à l'environnement vont augmenter. L'importance croissante du savoir dans l'économie aura en général pour effet d'accroître le rendement de la formation, ce qui devrait accentuer les inégalités de revenu au sein des pays. Ces inégalités n'augmenteront pas automatiquement avec le revenu avant impôt, mais les pouvoirs publics auront peut-être du mal à les atténuer, en raison de l'intégration commerciale et de la mobilité croissante des assiettes fiscales, ainsi que des fortes pressions budgétaires auxquels ils sont soumis. Ce document examine les solutions que les politiques structurelles nationales peuvent offrir à ces problèmes et à un certain nombre d'enjeux connexes ; il souligne également le besoin croissant d'une coordination et d'une coopération internationales face à ces questions au cours des 50 prochaines années.

Classification JEL : F, H, I2, I3, J1, O3, O4, Q5

Mots clés: Economie mondiale, croissance, changement technologique, inégalité, répartition des revenus, immigration, dégâts environnementaux, changement climatique, enseignement supérieur, consolidation fiscale, réformes structurelles, interdépendance, coordination, prévisions. 


\section{Policy Challenges for the Next 50 years}

\section{Key messages}

- More than five years after the onset of the financial and economic crisis the world economy is still weak, with growth in most key regions remaining below pre-crisis levels. Unemployment rates in the OECD remain high and productive capacity in the region has deteriorated. To support the recovery and minimize risks of a relapse into stagnation, monetary policy needs to remain very accommodative for some time, while fiscal consolidation needs to proceed in line with plans. Furthermore, growth- promoting structural reforms are needed, in both OECD countries and many emerging economies, while stability in the financial sector needs to be enhanced. In combination, such policies could foster a stronger recovery, ensuring that potential growth does not remain permanently affected by the crisis, and gradually remove slack in economies.

- As the effects of the crisis eventually subsides, the coming 50 years will likely see a major shift of economic balance towards emerging economies, particularly those in Asia, with the share in world GDP of non-OECD countries rising well beyond that of the current OECD area by 2060. Economic growth will continue to lift masses of people out of poverty, integrating them in the world economy.

- In the period to 2060, global growth prospects seem mediocre compared with the past, with GDP in the OECD and the emerging G20-countries likely to grow by $2.7 \%$ in $2010-2060$, compared to $3.4 \%$ in $1996-2010$. Global GDP is expected to grow by $3.0 \%$ per annum $2010-2060$, leading to an increase in global GDP of $350 \%$. While growth will be more sustained in emerging economies than in the OECD, it will still slow due to a gradual exhaustion of the catch up process and less favourable demographics in almost all countries. Population ageing will result in a decline in the potential labour force which can only partially be offset through increases in labour force participation and employment rates. Against this backdrop, future gains in GDP per capita will become more dependent on accumulation of skills and, especially, gains in multifactor productivity driven by innovation and knowledge based capital.

- Especially in Asia, growth could be curbed further by the rising economic damages from environmental degradation due inter alia to climate change, which are likely to affect these countries earlier than expected. By 2060, environmental damages in South and South-East Asia may lower GDP by more than 5\% compared to the central scenario.

- Global integration is likely to continue, but at a slower pace. Still, increases in trade intensity will be significant, and by 2060 euro area exports to Asia and emerging economies may be equivalent to $15 \%$ of GDP and similar in size to trade within the euro zone. Increased crosscountry interdependence will help share the burdens of shocks globally, but will also make the global economy more vulnerable to imbalances and a number of domestic policy instruments less potent. As the skill composition, capital intensity and consumption patterns of emerging economies gradually converge towards those of the OECD, production structures in these economies will increasingly resemble those in OECD countries.

- Addressing the trends behind the faltering growth performance will require policy changes. Countries can improve growth prospects by implementing policies that focus on four key areas: accelerating global integration (including encouraging migration flows), making institutions more resilient to shocks (e.g. demographic ones), curbing emissions to mitigate climate change and, especially, making the most of the knowledge economy, which will be the main driver of global growth in the future. The following broad policy areas (for which more detailed recommendations are discussed in the paper) would need to be addressed:

- Implement further multilateral trade and investment agreements and pursue migration policies aimed at filling gaps in skills and labour participation, which will have to be 
supported by policies that favour entrepreneurial activity and worker mobility (e.g. pension portability).

- Enact social insurance reforms to maintain labour supply in the face of rising longevity and an ageing workforce, while making retirement systems more resilient to productivity and demographic shocks.

- Ensure that strong demand for education and skills, stimulated by rising skill premiums and prolonged working lives, can be translated into work-related skills that match the demand for jobs.

- Ensure that product and labour market settings make it possible for young and highproductive firms to expand fast and encourage firms to innovate, without unduly favouring incumbents (e.g. in the area of R\&D subsidies and IPR).

- Prevent environmental damages from slowing down growth by taking early action to avoid locking in emission-intensive infrastructure and promote a shift toward a cleaner development path. This can be achieved through a policy mix of appropriate pricing of carbon and reform of fossil-fuel subsidies, complemented by more targeted measures.

- In some cases, pro-growth policies may entail trade-offs relative to other policy objectives. For example, if increased investment in tertiary education were to be solely financed with public funds, public spending in OECD countries could increase by on average 1\% of GDP by 2060. Given already large fiscal challenges stemming from the crisis, rising fiscal pressures from ageing and high cross-country mobility of the high-skilled, reforms to ensure that the beneficiaries of higher education carry a larger share of the funding burden should be pursued.

- In other cases, trade-offs may be more deep seated. With growth increasingly driven by knowledge and skills, growth in itself could keep generating rising tensions and inequalities. On current trends, earning inequality in the average OECD country may have risen by more than $30 \%$ in 2060 and would then face almost the same level of inequality as is seen in the United States today. Moreover, structural adjustment will continue, especially across firms within sectors (e.g. from low to high productivity and from polluting to less polluting firms) and in emerging economies, and the consequences for workers' wellbeing will have to be managed. If left unaddressed, such increases in inequality and costs of adjustment could eventually backlash on stability and growth.

- However, the scope for domestic public policy to address these tensions and inequalities will sometimes be limited. In some regions constraints will arise from the very need to redress existing imbalances and address future pressures, especially in the fiscal domain. In some areas, traditional redistributive tools and flanking policies may become more costly and difficult to implement due to increasing cross-country mobility of tax bases in the context of rising trade and investment integration.

- One way to face this conundrum is to use a wide range of policy tools to address inequality concerns and adjustment costs, such as :

- Increase equality of opportunities in education, with a special focus of public resources on early years and, possibly, life-long learning initiatives. As mentioned, funding reforms to ensure sufficient growth in tertiary education are also needed.

- Adjust tax and welfare systems to increasing mobility of capital and labour, e.g. by shifting taxation towards immovable factors (e.g. property and extraction of natural resources) and reform employment regulations, benefit systems and activation policies to support workers' mobility and ensure better matching of skills to jobs. Such policies can 
raise employment and thus lower income inequality, even though they may not help to lower earning inequality.

- Broaden welfare systems that provide important insurance against individual shocks and macroeconomic risks, accompanying them with conditionality to ensure their sustainability.

- In this context, an emerging policy dilemma is that increased reliance on tax revenues from immovable factors will be made more difficult by their shrinking role in a knowledge economy driven by intangibles, which are by nature more mobile across borders.

- Global coordination and cooperation will become increasingly necessary in areas where unfettered cross-country rivalry and coordination failures could harm global wellbeing. It is, for example, obvious that climate change mitigation has to be pursued on a global level, as domestic benefits of unilateral action are small. However, rising global integration and rising reliance on knowledge-based assets will also increase the need for international coordination in the following areas:

- Pursuing further trade and investment liberalisation in a multilateral fashion produces larger benefits than regional trade agreements.

- Lack of cooperation in areas where tax bases are mobile can generate negative externalities, for example in terms of high emissions (when their implicit or explicit price differs across countries), loss of fiscal revenues and rising inequalities (when corporate taxes are eluded). Further global integration (and build-up of environmental risks) will broaden these externalities and increase potential benefits from international coordination.

- The growing importance of knowledge based capital for growth - combined with the increased internationalisation of such capital - raises several issues. Incentives for individual countries to support basic research may fall. At the same time, more international cooperation on intellectual property rights and competition law enforcement may be needed as knowledge-intensive multinational firms will likely play a bigger role in the global economy.

- Increasing trade integration will make business cycles more synchronized across countries, lowering the efficacy of domestic stabilization and widening the scope for, and benefits from, international coordination. Nevertheless, policy makers will have to deal with the fact that the world economy is becoming increasingly multipolar with emerging economies constituting a larger share. This may make coordination more complex as the number of key stakeholders - often with different perspectives and policy priorities - increases. 
1.

Introduction

1. More than five years after the onset of the financial and economic crisis the world economy is still weak, with most key regions continuing to underperform pre-crisis developments, let alone recovering the losses accumulated during the crisis. Unemployment in the OECD area remains high and productivity growth sluggish. Many of the emerging economies that provided support for the global economy in the immediate aftermath of the crisis have decelerated. The road to recovery is ridden with constraints that are partly conjunctural and partly depending on longer-term challenges that were made more acute by the crisis.

2. The reasons for the depth and length of the crisis are several, ${ }^{1}$ but many of the tensions and imbalances that fed the crisis resulted from deep-seated trends that are unlikely to reverse in the coming decades, at least without major changes in policies. Examples of such trends are unprecedented demographic change as longevity increases and fertility remains low; build-up of current account imbalances; and rising polarisation of incomes as continued technological progress disproportionately benefits high skilled individuals. Similarly, the rising importance of non-OECD economies and globalisation are likely to continue, with expanding global supply chains and growing interlinkages among trade and investment partners. While the latter has helped sustain growth during global expansions it also contributed to spread the crisis and share its burdens. Unrelated to the crisis, but fundamental for future growth and welfare, is how to address environmental degradation especially at the global level. Assessing how these trends may evolve and interact can help understand future challenges, risks and opportunities for the global economy.

3. National, regional and global policies to deal with these challenges over the coming fifty years lie at the heart of this paper. Using a combination of modelling tools recently developed within the OECD, the paper analyses some key challenges facing OECD and non-member countries (covering on the whole 147 economies) over the long term, based on scenario analysis. The analysis revolves around a central scenario based on the OECD Economic Outlook long-term projections (for OECD and non-OECD G20 economies) supplemented with projections for the other 105 economies. Ancillary projections -- based on regression analysis and CGE simulations -- explore additional dimensions not covered in the Economic Outlook projections, such as technology, inequality, skill formation, migration and the environment. The narrative revolves around a central scenario that policy-makers may have to face if past trends (e.g. in ageing, migration, skill-bias in technical progress, globalisation and $\mathrm{CO}_{2}$ emissions) were to persist in the future. Given the many uncertainties, this scenario should not be seen as a forecast but rather as a device for thinking about future challenges in a systematic way and encouraging foresighted policy action in a number of interconnected areas where tensions might arise. In this context, numerical estimates are provided only to give a sense of the possible challenges. ${ }^{2}$

4. The paper aims at providing a multidimensional framework for thinking about the future in a structured way, focusing on how international and national policy settings would need to be re-examined and adjusted to make the most out of aforementioned trends and put the global economy on a sustained growth path. The framework is also used to lay bare tensions hidden in the central scenario and to explore how policies can affect outcomes in multiple dimensions, including growth, equity, and fiscal and environmental sustainability and stability. Finally, in some areas open issues are also flagged where no firm policy recommendations are given.

5. In short, the ultimate purpose of the analysis is to provide policy guidance, considering likely long-term changes in underlying economic structures and in the context of multidimensional policy objectives. The focus will be on how the insights from the analysis in this paper lead to new or revised recommendations in the structural policy domain. Hence, policy recommendations specific to smoothing out cyclical developments or that are deemed to be unaffected by insights from this paper are not

1 Among them, the complex and excessive build-up of imbalances within and between countries and sectors; an increasing global financial interdependence; and a lack of national, regional and global institutions that could deal with the related policy challenges in an effective and comprehensive way.

The cut-off date for data used in designing the scenarios is 15 April 2014. This means that recent PPP updates for emerging economies are not incorporated. 
necessarily highlighted (Box 1). Furthermore, issues relating to the evolution of the financial sector are not addressed as they constitute the focus of a companion paper. ${ }^{3}$

\section{Box 1. Issues not dealt with in this paper}

Despite (and because of) the broad approach of this paper, a number of demarcations apply. Specifically, this paper does not:

- Focus on cyclical developments, such as policies to support the recovery in the short-term.

- Deal with how the regulatory system for the financial sector will evolve as a consequence of the lessons learnt from the recent crisis. Thus, the structure of the financial sector and the global interlinkages it will provide will not be analysed. The main reason for this exclusion is the lack of modelling tools connecting the financial sector to other parts of the economy.

- Focus on the risks of emerging economies facing markedly weaker growth as a consequence of insufficiently strong institutions (the so-called "middle-income trap").

- Analyse policy settings and the specific challenges that non-OECD non-G20 countries face. In particular, developing economies are largely outside the scope of this paper, in spite of their potential for strong growth and the significant policy challenges they face.

- Deal with detailed aspects of subject areas and country experiences. The focus is on broad global or regional trends and drivers, as well as the main connections across policy areas and countries.

- Produce a set of fully consistent scenarios leading to radically alternative pathways based on different assumptions about exogenous factors. Rather it uses different tools to identify tensions in the baseline scenario and to analyse how specific policies may contribute to relieve them.

- Focus on policy recommendations that - while being relevant for OECD countries - are not deemed to be altered by what is known about long-term trends in the global economy. Rather, the focus will be on how insights from this analysis may lead to new or revised policy recommendations.

6. The conditions for national policy making will likely change substantially over coming decades. Economic growth will slow and become increasingly dependent on innovation and knowledge-based assets, where economic dividends tend to be unevenly distributed across both income groups and countries. This sharpening growth-equity trade-off may become even more acute as further global integration and international competition for knowledge-based activities makes traditional redistributive tools (based on taxes and transfers) more difficult to use within countries. Pursuing policies that promote equity in opportunity, e.g. in terms of education and training, could mitigate the trade-off but would have to be pursued in an environment with mounting fiscal spending pressures and risks of eroding tax bases. As economic integration proceeds, interdependence across borders will increase. This will have several implications. First, the effects of economic shocks will in many cases be shared with trading partners to a larger extent, reducing volatility and risks for individual countries. In the same vein, international spillover effects from policies are likely to increase too, in some cases pointing to benefits from further international policy coordination.

7. In addition environmental pressures from climate change will rise, becoming an increasing drag on economic growth. Given the global nature of greenhouse gas emissions, effective mitigation will require coordinated global action.

8. While demand for international policy coordination therefore will increase, policy makers will have to deal with the fact that the world economy is becoming increasingly multipolar as emerging economies will form a growing share of the world economy. This may make coordination more complex 
and difficult as the number of key stakeholders - often with different perspectives and policy priorities will rise. ${ }^{4}$ Moreover, in the shorter run, the legacy of the crisis also tends to make coordination both urgent and harder to achieve. Overcoming these tensions is crucial for successfully managing phenomena with large global spillovers like current account imbalances, migration flows, emissions of greenhouse gases and management of intellectual property rights.

9. The remainder of this paper is organised as follows. Section 2 describes the central scenario, and identifies a number of tensions in and related to it. The following sections deal with five key policy challenges that policy makers are likely to face over coming decades: slowing growth, rising inequality in market incomes, growing economic drag from changes in climate, increasing fiscal pressures, and challenges to economic stability. Section 3 deals primarily with policies to pursue growth, and the potential side-effects and spillovers such policies can generate. Section 4 analyses policies to address rising earning inequalities and how these policies may spill over onto growth and employment. In section 5 , policies to mitigate the economic impact of environmental damages are analysed. Section 6 focuses on fiscal challenges, while section 7 deals with macroeconomic stability and policies. Section 8 concludes by summarising the main areas in which new policy thinking is needed.

\section{Key developments in a central scenario: 2010-60}

\section{Box 2. Main trends}

- The balance of the world economy will continue to shift towards emerging economies and, especially, Asia. By 2060, the share of global GDP accounted for by non-OECD economies will be significantly larger than the share of the current OECD area. Global GDP growth is projected to slow from an annual average rate of 3.6\% between 2014-2030 to $2.7 \%$ from 2030-2060, owing to decreasing potential for catching-up, slower increases in human capital stocks, and shrinking labour forces. Uncertainty about productivity growth, future improvements in educational attainment and slowing immigration into the OECD are main risks.

- Global trade integration will continue to grow in the central scenario, but at a slightly slower rate than seen during recent decades. The shift in trade patterns will reflect shifting economic balances, with exports from non-OECD countries rising from $35 \%$ of world exports in 2012 to $56 \%$ in 2060. Specialisation patterns will continue to evolve, partly reflecting more rapid upskilling in emerging economies. For example, China and other Asian countries will continue to specialise in electronics and increasingly in services, while the manufacturing sector will continue to shrink in the OECD. Global value added chains may develop further.

- Emissions of greenhouse gases are expected to double between 2010 and 2060 in the central scenario. Such a development would affect economic output, possibly lowering global GDP by $1.5 \%$ in 2060 compared to the central scenario. Impacts will likely be heterogeneous amounting to up to $5 \%$ of GDP loss in the worst hit regions (South and South-East Asia), while some other regions may actually initially see increases in GDP relative to the central scenario.

- Earning inequalities may rise by more than $30 \%$ in the OECD area and by roughly $20 \%$ in other G20 economies until 2060, which would mean that the average OECD country could face by then the same level of inequality as currently experienced by the United States.

- Fiscal requirements to stabilise debt ratios at $60 \%$ levels in the context of rising pension, health and education spending pressures are estimated to be over $7 \%$ of GDP for the average OECD country by 2060. Additional fiscal risks for OECD countries entail weakening revenues due to less migration and more mobile tax bases.

- Global current account imbalances may rise in the medium term unless bold fiscal and structural reforms are pursued. coordination. 
10. The central scenario described here has been developed using a set of models describing macroeconomic developments (Johansson et al., 2013), trade developments (Johansson et al., 2014), greenhouse gas emissions (Chateau et al., 2014) and income inequalities (Braconier et al.,2014). The models used for producing the central scenario are described in Box 3.

\section{Box 3. The central scenario and its modelling base}

Forward-looking scenarios are constructed using a set of models, each describing one or several key variables (See figure, where each model is illustrated as a circle with reference to relevant descriptions). Models are connected through a set of linkages whereby endogenous outputs from one model form exogenous inputs to other models, giving a recursive structure. All models are also dependent on exogenous inputs (e.g. policies).

\section{Long term growth projections}

First, a long-term growth scenario is generated for OECD and non-OECD G20 economies: this includes the supply side of the economy as well as national savings, investment and current account balances (Johansson et al., 2012). The central scenario used in this paper is identical to the one used in the OECD Economic Outlook no. 95 (OECD, 2014), and is based on a set of assumed future policy changes, including (See OECD, 2014a for further details):

- For labour force participation up until 2030, recently legislated pension reforms are assumed to be implemented and participation rates of older workers are adjusted accordingly. After 2030, the share of active life in life expectancy is assumed to remain constant, implicitly assuming that the retirement age is indexed to longevity.

- For countries with gross general debt levels in excess of $60 \%$ of GDP, fiscal policy is assumed to adjust such that debt converges to this level. For countries with gross debt levels at or below this threshold, fiscal policy is set to stabilize debt as a share of GDP. Potential effects on public budgets from population ageing, pressures on health spending, and rising demand for tertiary education are not explicitly embedded in the model (though their implications for the model-based fiscal gaps are discussed).

- Product market and trade regulations are assumed to gradually converge towards the average regulatory stance observed in OECD countries in 2011 for countries where regulations are currently more restrictive, but remain constant for other countries.

- For non-OECD G20 economies, a gradual increase in public spending on social protection is assumed until it reaches a level that is equivalent to the average OECD country. This increase amounts to an average of four percentage points of GDP.

- Educational attainment continues to rise and converge across countries, with mean years of schooling approaching 18 years in the very long run (beyond 2100).

- Credit availability is assumed to improve with financial market deepening. The pace of expansion of credit availability is assumed to be fastest in emerging economies that start from relatively low levels of financial market development.

The outputs from the long-term growth projections feed into a number of different modules describing other dimensions of the central scenario (illustrated with non-dashed arrows):

- The trade and specialisation model described in (Johansson and Olaberría 2014) is used to generate bilateral trade patterns consistent with the Economic Outlook long-term growth scenario. This model contains two parts: a macroeconomic growth model (MAGE) covering 147 countries/regions, which is calibrated to mirror the OECD long-term scenarios for the OECD and G20 countries (42 countries), and complement it with MAGE scenarios for the other 105 countries and regions. These long-term scenarios are then imposed into a detailed multi-sector computable general-equilibrium (CGE) model (MIRAGE-e) that simulates production, specialization, trade, prices and wages across countries and industries. Policy assumptions include that already agreed trade agreements will be implemented. 
- The ENV-Growth and ENV-Linkages models, described in Chateau et al. (2014), are used to generate predictions on emissions of greenhouse gases, consistent with the long-term growth and trade scenarios. The models have a similar setup as the MAGE and MIRAGE models (with a macro part and a CGE part), but with a stronger focus on sectors with large environmental impacts, and on emissions of greenhouse gases. Calibration is made in the same way as for MAGE/MIRAGE-e.

- An earning inequality equation, described in Braconier, H. and J. Ruiz Valenzuela, 2014, is used to generate scenarios for gross earning differentials, conditioned on inputs from the OECD long-term scenarios.

\section{Generating the central scenario}

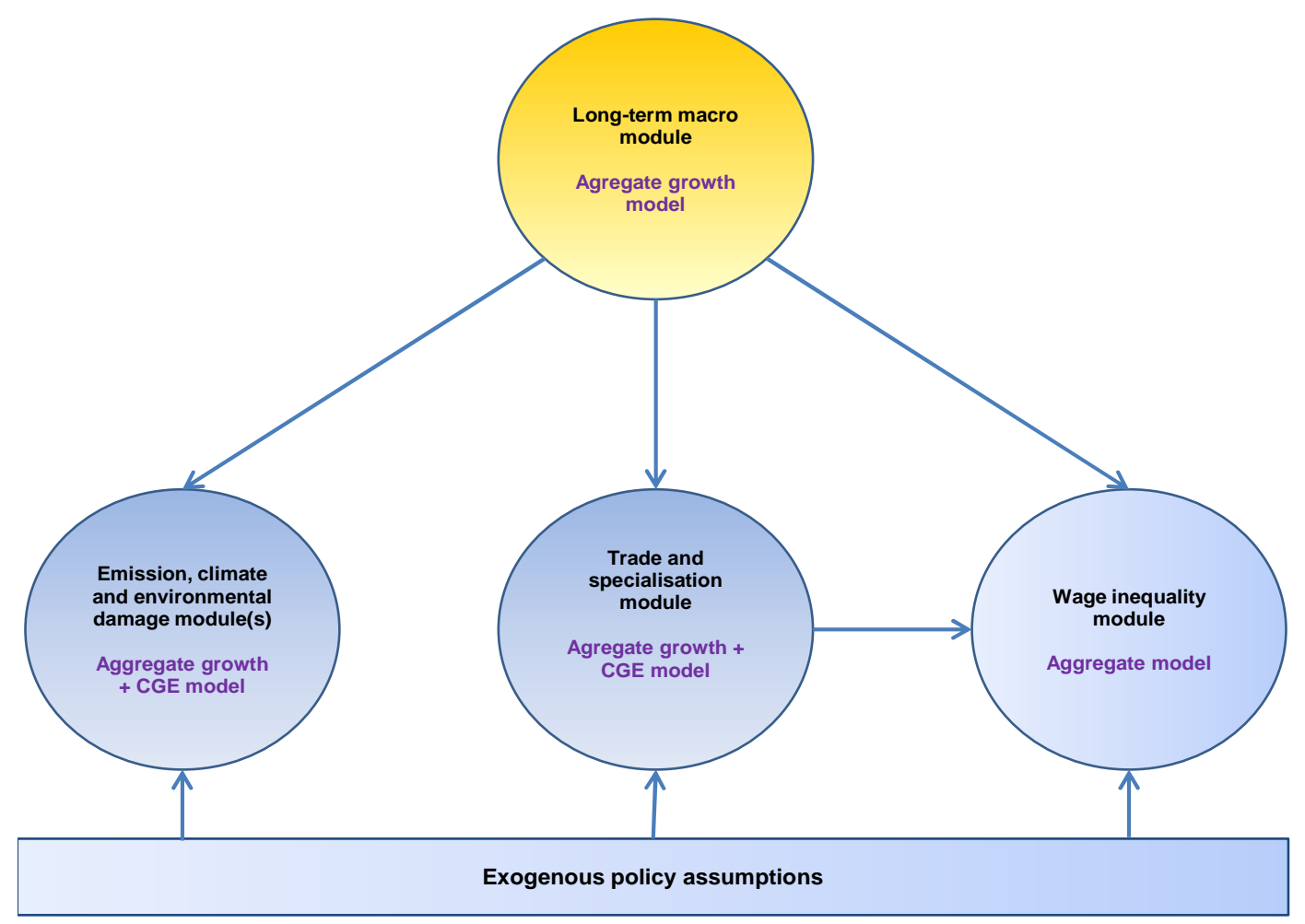

\subsection{Global growth is set to slow over the coming fifty years}

11. As discussed in detail in $\operatorname{OECD}(2014)$, the recovery from the global financial and economic crisis remains weak and tentative. Several trends that fed the boom and the subsequent bust remain - including overstretched households and governments and excessive reliance on financial services - and continue to weigh on the recovery. At the same time, the crisis inflicted some long-term damages to economies, through low investment, high unemployment and weak public finances that may weaken future prospects. In order to support the recovery and minimize risks of a protracted stagnation, monetary policy needs to remain very accommodative for some time, while fiscal consolidation needs to proceed in line with plans. Furthermore, growth-promoting structural reforms are needed, especially in Japan, the euro area and in many emerging economies. Phasing in higher capital requirements for banks and lower leverage in the private sector could support financial stability, and would also likely improve long-term growth prospects, at least in OECD countries. In combination, such policies could foster a stronger recovery, ensuring that potential growth does not remain permanently affected by the crisis, and gradually remove slack in economies. 
12. In a longer perspective, potential growth in OECD and non-OECD economies is set to slow over the period to 2060, even though a rising share of fast growing non-OECD economies in global output should dampen the slowdown at the global level (Figure 1; Johansson et al., 2013). Global GDP may rise by around 350\% between 2010 and 2060 and, with growth driven by emerging economies, the economic centre of gravity will shift further towards Asia. By 2060, the share of non-OECD countries in world GDP will be significantly larger than that of the current OECD countries. In general, the moderation in growth among OECD and G20-countries owes to three main factors:

- $\quad$ Multifactor productivity (MFP) growth in most economies is expected to slow, consistent with some weakening in the growth of R\&D intensity (Fernald and Jones, 2014). In the OECD, average annual MFP growth is anticipated to fall from 1.1\% in the decade to 2030 to $1.0 \%$ to 2040 and $0.9 \%$ to $2050 .^{5}$ MFP growth in some non-OECD countries that have grown rapidly in recent years through catching-up is likely to slow more sharply as GDP per capita in these countries converges closer to OECD levels (Figure 2, panel A).

- While average levels of educational attainment will continue to rise, the pace is set to slow in the central scenario (Figure 2, panel B). This expected slowdown in the growth of human capital is consistent with roughly constant returns to investment in education (Johansson et al., 2013).

- The demographic dividend of rising participation rates, fewer dependent children and low shares of elderly citizens is bound to gradually disappear (Figure 2, panel C). The share of population that is of working age started to fall in Japan in the late 1990s, is close to its peak in the OECD, has stopped increasing in China, while it should continue to rise until 2050 in India (OECD, 2013a). Between 2010 and 2060, the OECD's population is expected to increase by 17\%, but the working age population (age 15-74 years) may fall by $7 \%$. The central scenario assumes that further retirement and labour market reforms will be implemented to prolong working lives in line with rising longevity. Even though these assumed reforms may increase labour force participation rates in the OECD by on average $2.4 \%$ percentage points, labour's contribution to growth in GDP per capita is likely to be close to nil throughout the period in the average OECD country and will eventually turn negative in the average non-OECD G20 country (Figure 2, panel A). details of the methodology, see Johansson et al., 2012), hence growth will tend to be lower than in a measure that controls only for labour (unadjusted for human capital) and capital inputs. The MFP projections are a function of growth at the technological frontier, changes in product market regulations and convergence to the frontier. The presented numbers refer to MFP, which differs slightly from the concept of labour efficiency presented in the Economic Outlook Long-term Database. Specifically, log(MFP) $=\log ($ labour efficiency)*(labour share), with the labour share held constant at 2/3 in the long-term central scenario. 
Figure 1. Global GDP growth is set to slow down over the next 50 years, 2010-2060

Contribution of OECD and non-OECD to global GDP growth (annual average, constant 2005 PPP)

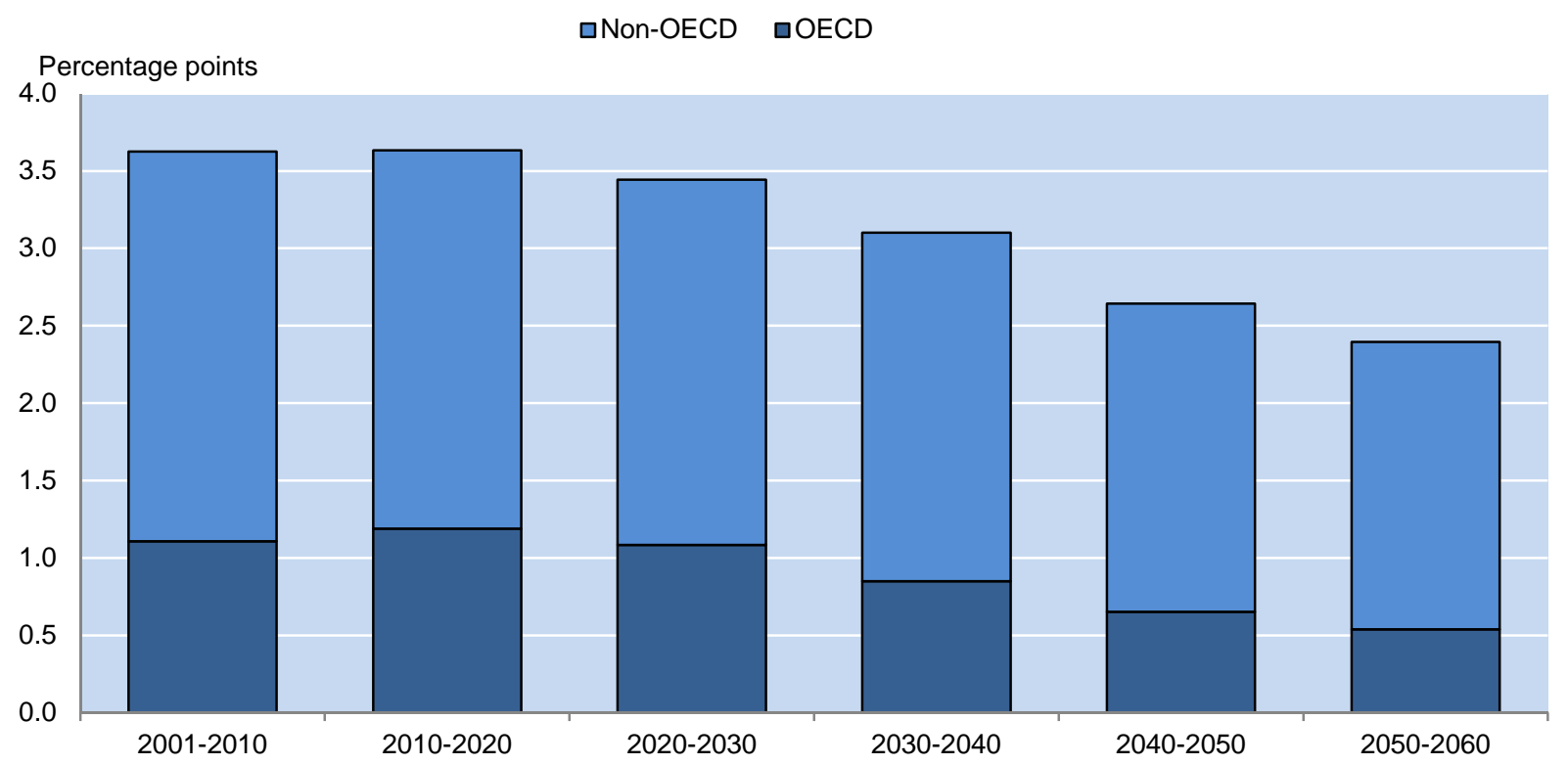

StatLink ज्ञाज्ञ http://dx.doi.org/10.1787/888933094412

Note: The charts combine the long-term projections for 42 countries published in the OECD Economic Outlook 95 and, for all other countries, projections from the ENV-growth model of the OECD Environmental Directorate.

Source: OECD Economic Outlook 95 long-term database, OECD computations. 
Figure 2. Developments in OECD and non-OECD G20-countries, 1990-2060

A. Contribution to growth in GDP per capita, 2000-2060 (annual average)

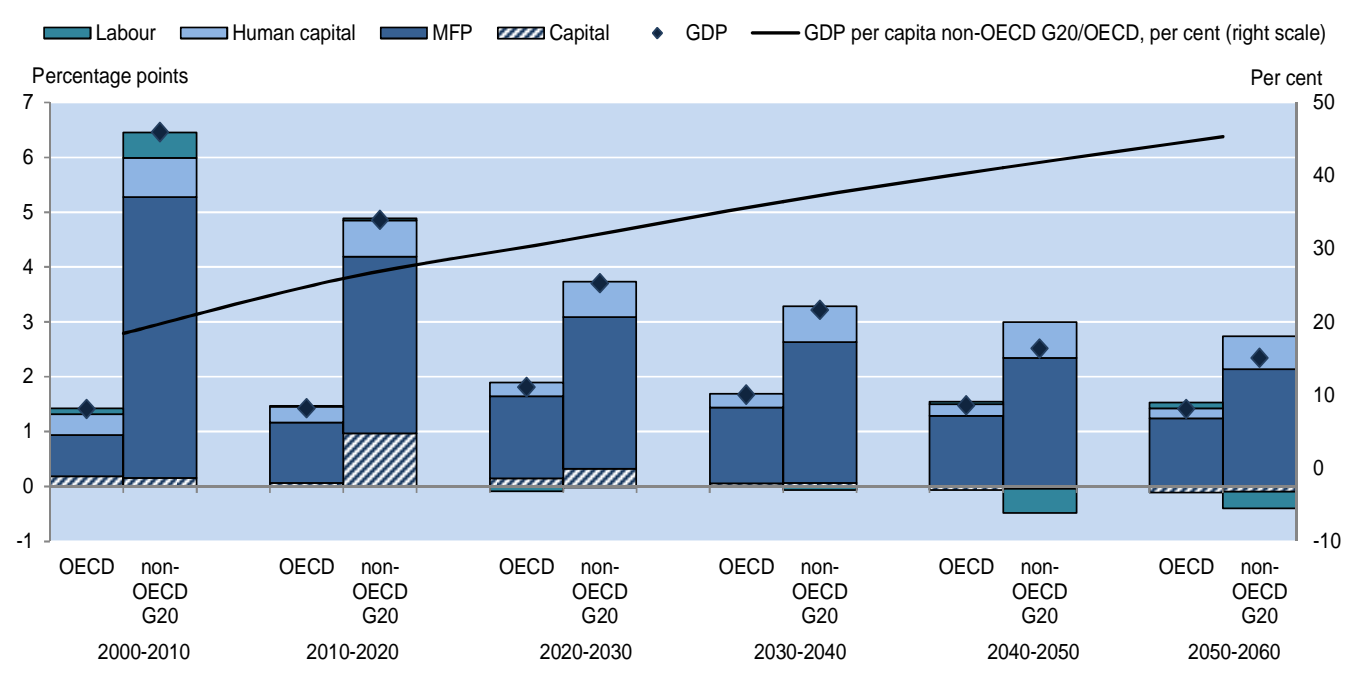

B. Mean years of schooling $1990-2060$
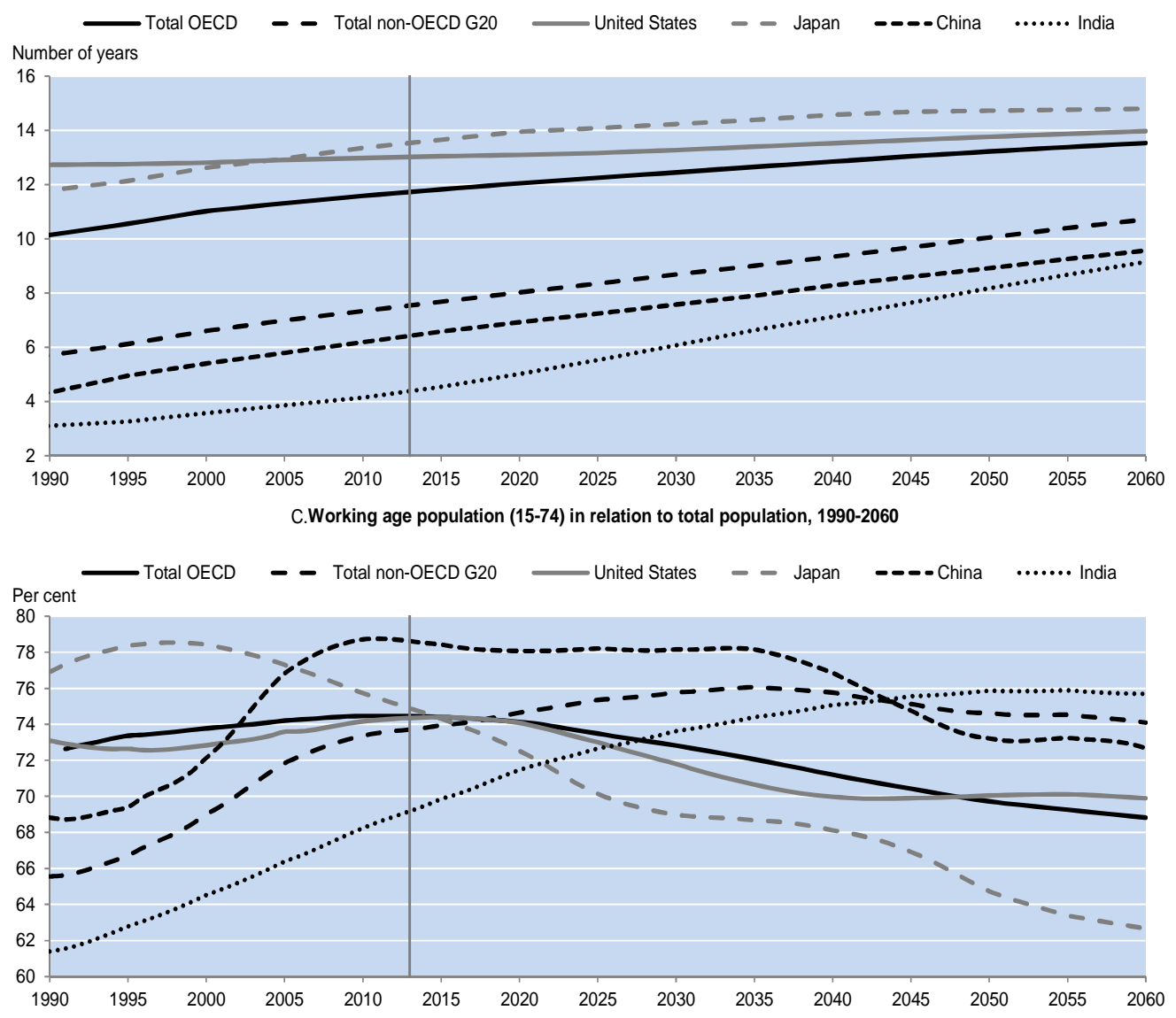

StatLink 젶ㄴ http://dx.doi.org/ 10.1787/888933094431

Note: The non-OECD G20 countries are Argentina, Brazil, China, India, Indonesia, Russian Federation, Saudi Arabia and South Africa.

Source: OECD Economic Outlook 95 long-term database, OECD computations. 


\subsection{Trade integration is set to grow, implying changes in specialisation even in the absence of} further major trade deals

13. Global trade integration will likely deepen over the coming 50 years, as transport costs continue to fall and trade barriers are lowered in line with already agreed trade agreements (Johansson et al., 2014). The pace of integration is likely to slow however, unless further agreements to lower trade barriers, transaction costs and regulatory obstacles are reached. The evolution of trade will also depend on the way firms define their strategies and their boundaries in global value chains, with counteracting forces coming from further reductions in trade and transaction costs, and new technologies (such as 3D printing) that may shorten physical value chains (De Backer and Miroudot, 2013). While world exports in relation to GDP tripled between 1950 and 1998 (Ventura, 2005), the increase between 2010 and 2060 could be around 60\%, although regional variations are large (Figure 3). As economic gravity shifts towards Asia, trade will follow the same path. OECD countries' share of world trade is estimated to fall from $50 \%$ in 2012 to $25 \%$ in 2060 (Johansson et al., 2014).

\section{Figure 3. Exports as a share of GDP will increase in all regions}

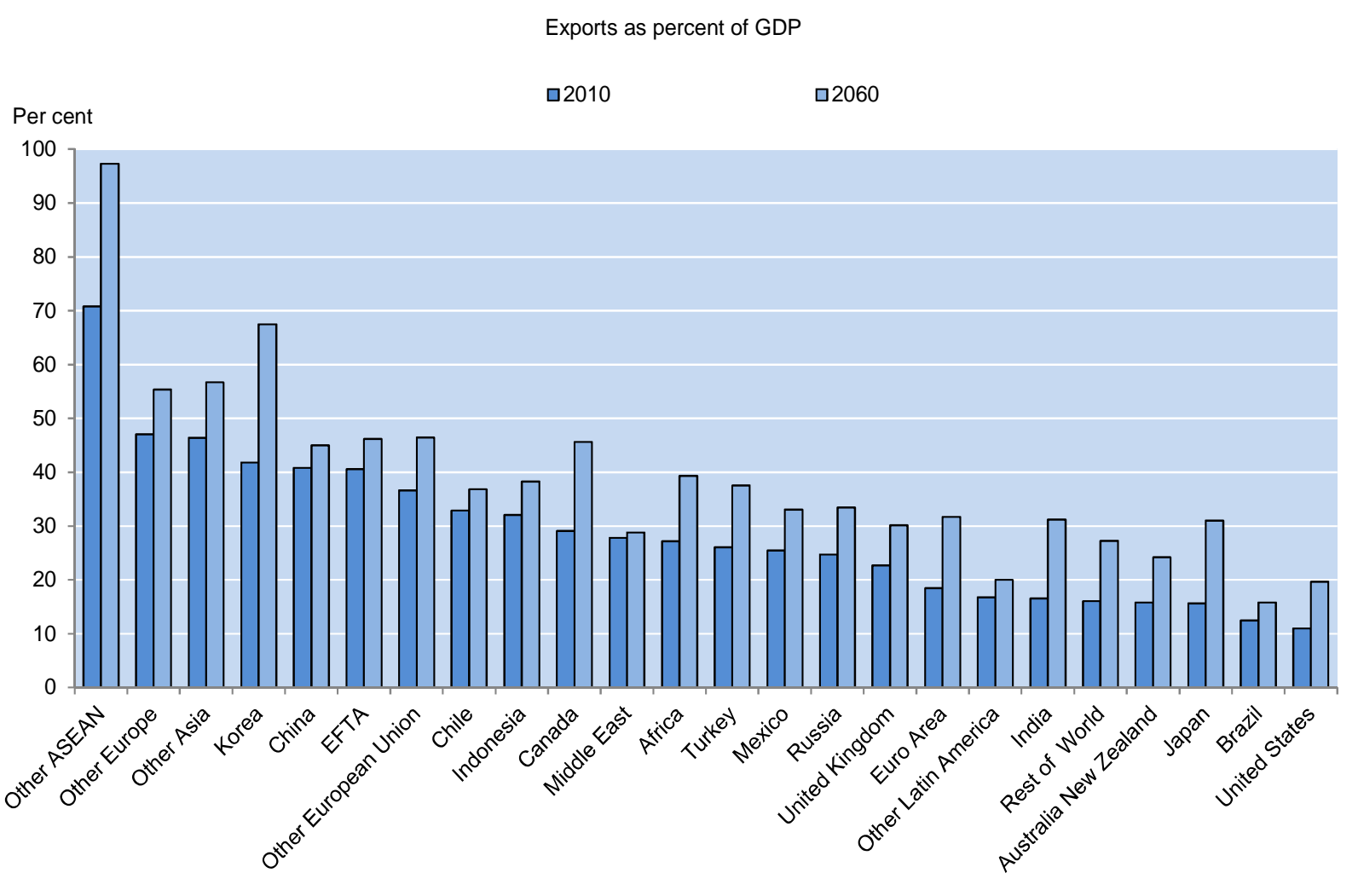

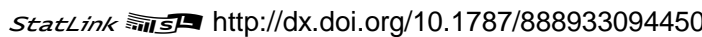

Source: Johansson, Å. and E. Olaberría, 2014.

14. Rising trade integration should have a sizeable impact on global patterns of production and specialisation. As emerging economies catch-up in terms of GDP per capita, their production structure should increasingly resemble the structure in OECD countries. China and other Asian countries may however continue to specialise in electronics and increasingly in services, while manufacturing may continue to shrink in the OECD. With or without further trade agreements, services will be more traded and trade policies will have to adjust to changes in the organisation of global value chains (Miroudot et al., 2013). 


\subsection{Earning inequalities are likely to continue to rise, reflecting skill-biased technological change and a slower growth in educational attainment}

15. In parallel, inequality in household disposable incomes has increased in most OECD countries in recent decades (Figure 4). Rising capital incomes (which tend to be highly concentrated), less redistributive tax and benefit systems and changing household formation patterns have all contributed to this outcome (OECD, 2011b; Hoeller et al., 2012), but the main driver of increasing income dispersion has been the widening gap in earnings. Top gross earnings (wages) in OECD countries - measured as the upper bound of the 9 th decile of the earnings distribution for full-time employed-have risen 0.6 percent faster per annum than those at the bottom (upper bound of the 1st decile) over the two decades up to the crisis (Braconier et al., 2014). This increase largely reflects that skill-biased technological change (SBTC) has more than compensated the effects of rising levels of educational attainment and per capita income growth, which both have tended to lower earnings dispersion. ${ }^{6}$ The pace of SBTC over the coming fifty years cannot be predicted with certainty, but a likely scenario is that past trends will continue, given that the direction of technological change has persistently been skill-biased over the post-war period.'

\section{Figure 4. Income inequality has increased in most, but not all OECD countries}

Gini coefficients of household disposable income inequality, mid-80s and late 2000s - mid 80s $\Delta$ late 2000s

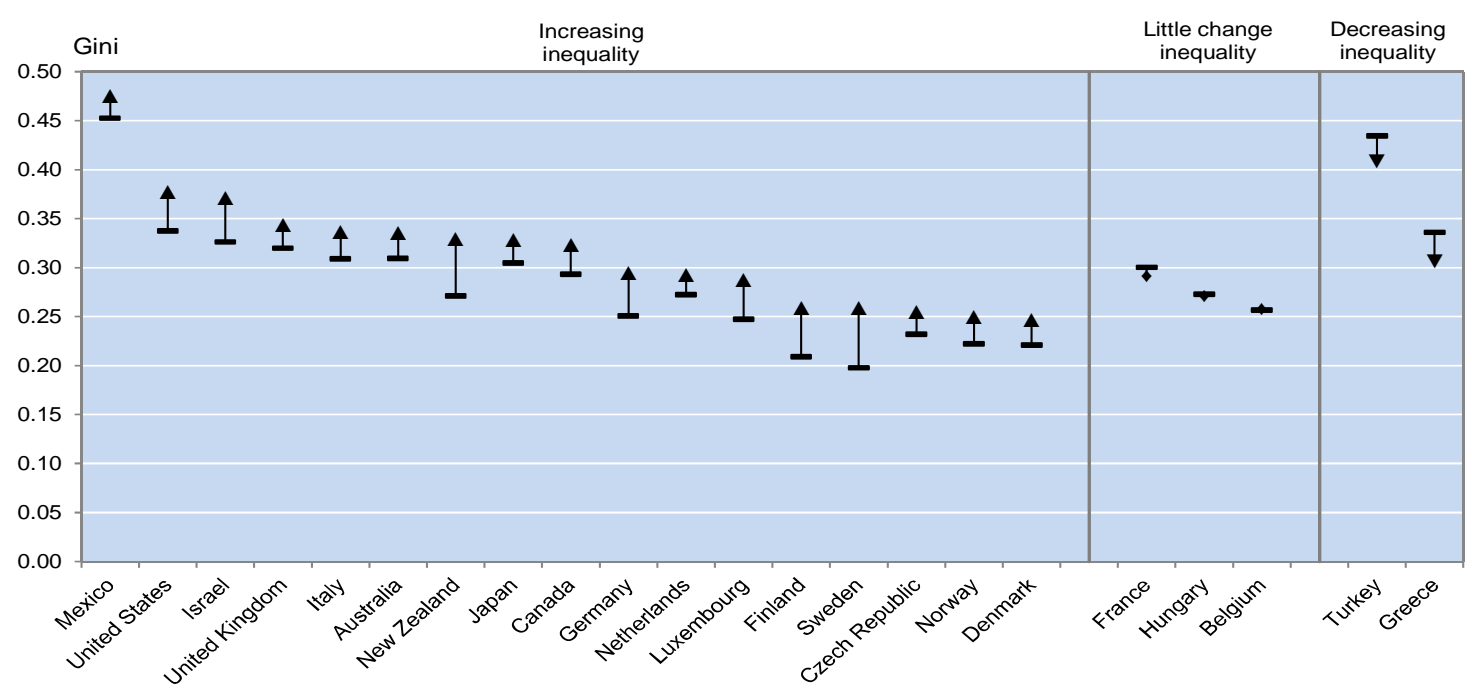

StatLink 部Sד http://dx.doi.org/10.1787/888933094469

Source: OECD Database on Household Income Distribution and Poverty.

See section 4 and Annex 1 on references to and evidence on income inequality and educational attainment as well as how rising per capita incomes seem to increase demand for less-educated workers and hence tend to lower earning inequality.

Potentially, a falling labour share in GDP could add to these distributional pressures, but such effects are not considered in the analysis. The labour share of GDP has fallen by 1.5 percentage points in the average OECD country between 1985 and 2010 and more than 5 percentage points in Germany, Ireland and New Zealand. The analysis in Annex 1 identifies rising multifactor productivity, rising trade exposure and female labour participation as drivers of falling labour shares. These factors could very well continue to exert downward pressures on the labour share in the future, contributing to increasing inequality in incomes and wealth (Piketty and Zucman, 2013). 
16. Assuming that historical trends and relationships prevail - while GDP and educational attainment grow in line with the long-term growth projections - the widening of earnings dispersion would accelerate slightly to $0.6 \%$ in the central scenario over the coming 50 years, as the moderating effects of improvements in educational attainment on inequality will further diminish due to progressively slower human capital accumulation.8 As a consequence, earning inequality could grow between $17 \%$ and $40 \%$ within the OECD (Figure 5, panel A). Earning inequalities in low inequality countries - like Italy, Sweden and Norway- might by 2060 be similar to those seen in the average OECD country today, whereas the OECD average in 2060 might be close to US levels today (Figure 5, panel B). Virtually all increases in earnings dispersion would take place between high- and medium-income earners, in line with recent evidence suggesting that technology increasingly replaces medium-skilled jobs, leading to earnings polarisation (Braconier et al., 2014; Goos et al., 2010; Causa et al., 2014).

17. In any case, it is important to note that, even with unabated SBTC, real earnings are expected to grow across the earning spectrum, suggesting that "all boats will rise", though not to the same extent (Figure 5, panel C).

More specifically, the central scenario assumes that relationships between earning differentials on one hand, and explanatory factors (multifactor productivity, the ratio of skilled to unskilled labour and product market regulation) on the other hand, remain the same going forward as they were the from the mid-1980s to the late 2000s. This means that technological progress is assumed to remain skill-biased to the same extent as experienced the last few decades. See Annex 1 for further details. 


\section{Figure 5. Earnings inequality and earnings}

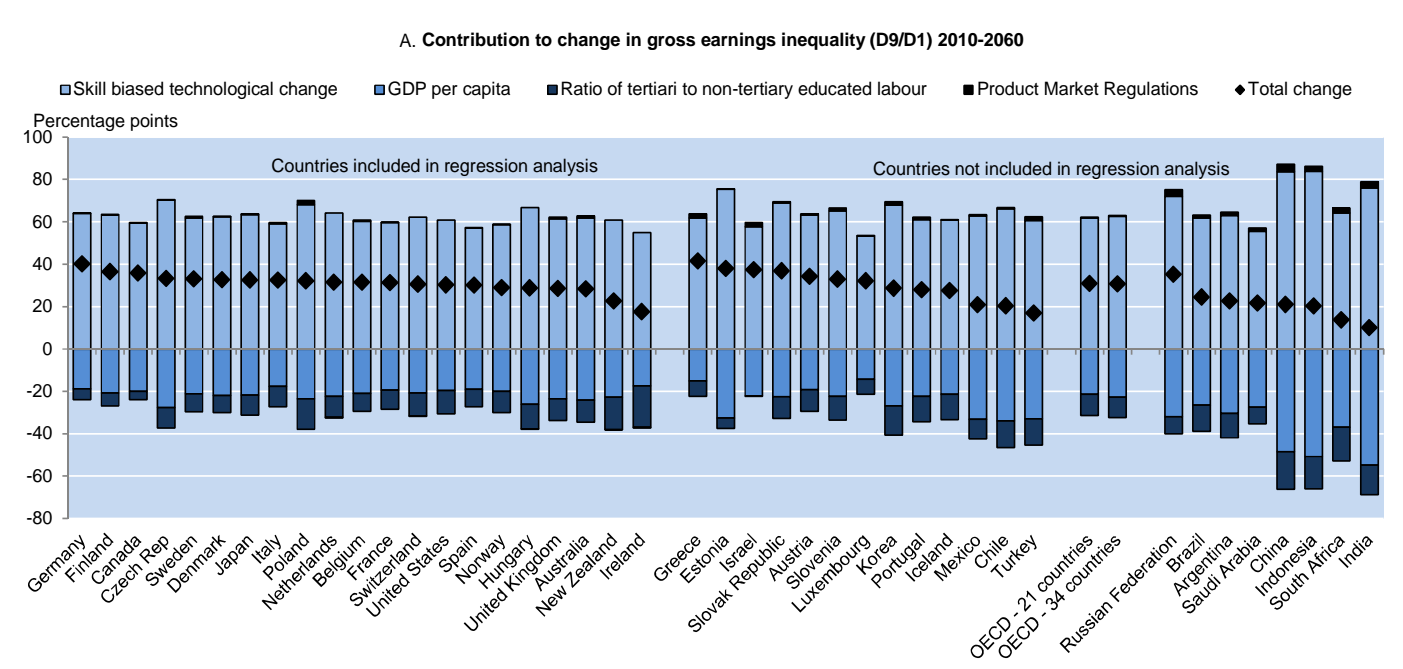

B. Gross earnings inequality (D9/D1) 2010 and 2060
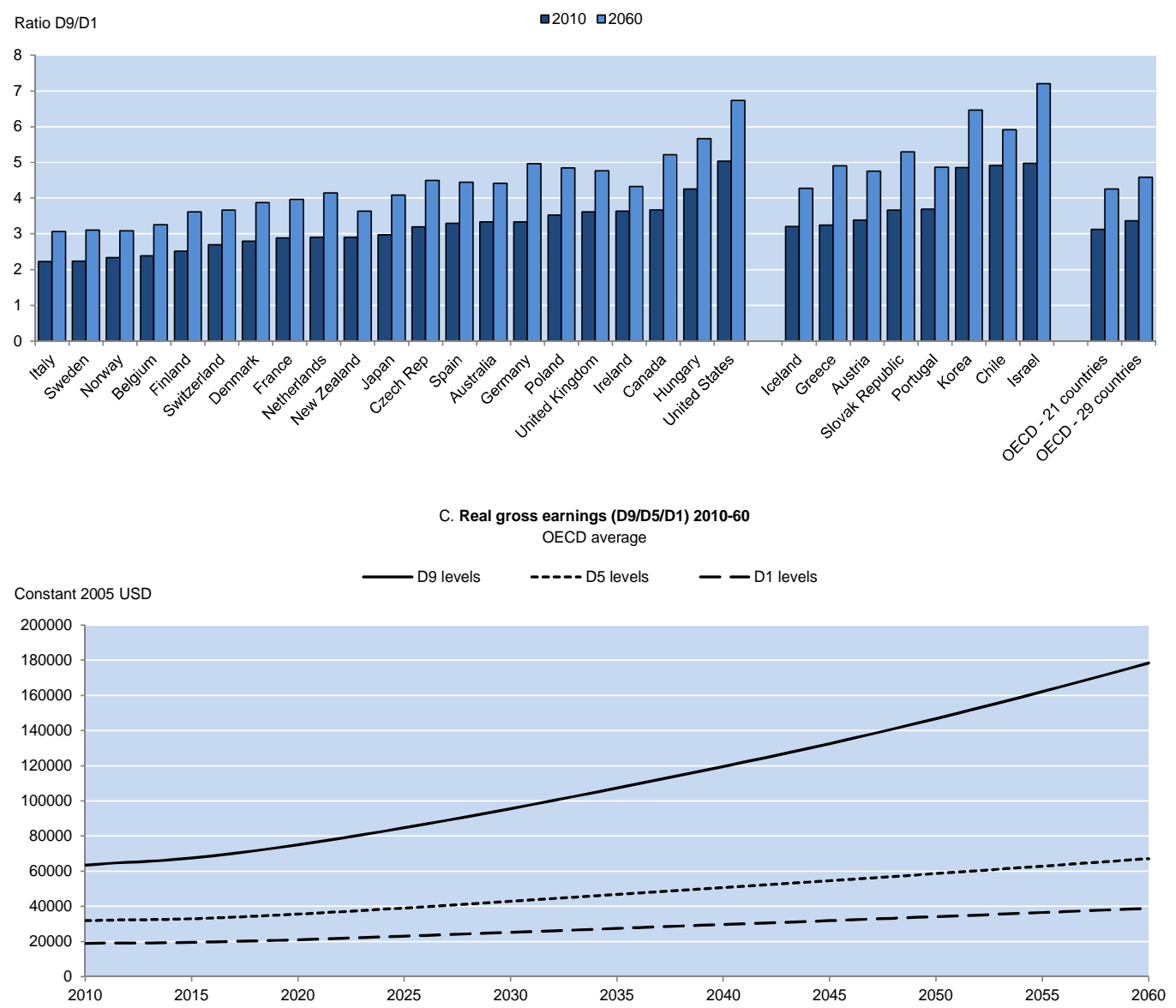

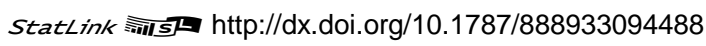

Note: Ratio of gross earnings (before tax and transfers) of the $9^{\text {th }}$ and the $1^{\text {st }}$ deciles of the earnings distribution.Skill-biased technological change is measured as the combined effect of the global trend and multifactor productivity (See Braconier et al., 2014). Product market regulation measures how deregulation markets will increase inequality.

Source: OECD calculations based on the OECD Economic Outlook 95 long-term database. 
18. Rising gross earning inequalities may not fully translate into increases in inequality in household disposable incomes. First, earning inequalities only relate to full-time employees, disregarding distributional effects from part-time work and employment. Second, they do not consider the mitigating impact of taxes and benefit systems (Joumard et al., 2012). However, the potential for rising earning inequality highlighted in the central scenario points to the size of the challenge that would have to be faced by redistributive policies. Consequences for policy making will be discussed in section 4 .

\subsection{Fiscal consolidation will require major efforts in several countries}

19. Fiscal pressures will build up in several areas over the coming decades unless extensive fiscal reforms are pursued. The legacy of the crisis - with often large increases in public debt - unfavourable demographics, and rising spending pressures in areas like health and education all contribute to substantial fiscal pressures (Fall et al., 2014). In the central scenario, these fiscal pressures are assumed to be resolved through a combination of fiscal and structural reforms (Box 3): with medium term (2030) fiscal consolidation, being achieved through both higher revenues and lower spending. Beyond 2030, retirement reforms are assumed to keep pension spending in relation to GDP constant while other spending are also assumed to stay constant in relation to GDP.

20. Despite these relatively benign assumptions, the additional budgetary effort required in several countries is significant though smaller than the effort already achieved by some European crisis countries (OECD, 2014). Figure 6 shows an estimate of the fiscal consolidation needed to reach the $60 \%$ public debt threshold by 2060 , based on initial fiscal gaps and the assumed constant spending ratios. These gaps are estimated to be more than 5\% of GDP in the UK and Spain and more than $13 \%$ in Japan. The effort required of most countries would be much stronger, however, if projected increases in pension, health and education spending ratios were taken into account (see section 2.6.4).

Figure 6. Fiscal gaps in the central scenario

Percentage points of GDP

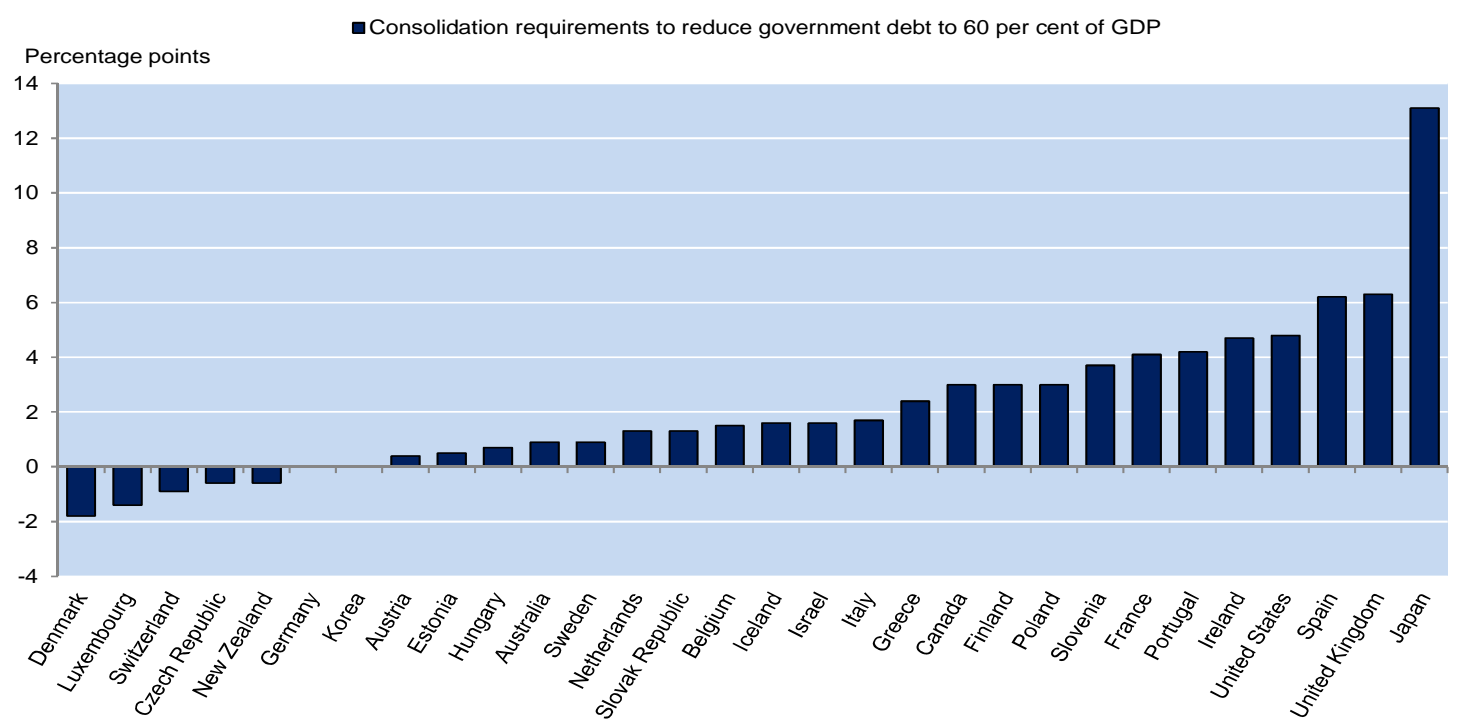

StatLink ज्ञाज http://dx.doi.org/10.1787/888933094507

Note: The long-term consolidation needs ("fiscal gap") measures the difference between the underlying primary balance as a per cent of GDP that keeps gross general government debt stable at $60 \%$ of GDP in 2060 and a baseline projection.

Source: OECD Economic Outlook 95 long-term database; OECD calculations.

21. In highly indebted countries, such fiscal pressures could be worsened by adverse movements in real interest rates. As discussed in OECD, 2014, shrinking savings due to demographic developments may push up real interest rates by as much as three quarters of a point between 2015 and 2060. Such increases 
would impact public finances via higher debt service, especially where public debt levels are high. Rising needs to replace ageing infrastructure and investment in the transition to a greener economy or to mitigate effects of climate change could also add to these pressures.

\subsection{Fiscal consolidation and structural reforms are needed to rein in global imbalances in the medium term}

22. Global current account imbalances narrowed during the crisis though they remain high relative to the pre-2000 period (Figure 7). Long-term demographic trends with more rapid ageing - and consequently faster falling savings - in surplus countries may push towards lower imbalances. ${ }^{9}$ Moreover, rising interest rates in net debtor countries with persistent current account deficits may push down investment, also dampening imbalances. However, this may not be sufficient to counteract rising imbalances in the medium term without further policy action (Ollivaud and Schwellnus, 2013). Ambitious fiscal consolidation in the United States, euro area deficit countries and Japan could stabilise imbalances. If fiscal consolidation is accompanied by structural reforms, imbalances could start to decrease (see Section 7.2)..$^{10}$

Figure 7. Global current account imbalances will increase

Sum of absolute current account balances, divided by 2 , normalised on world GDP (per cent)

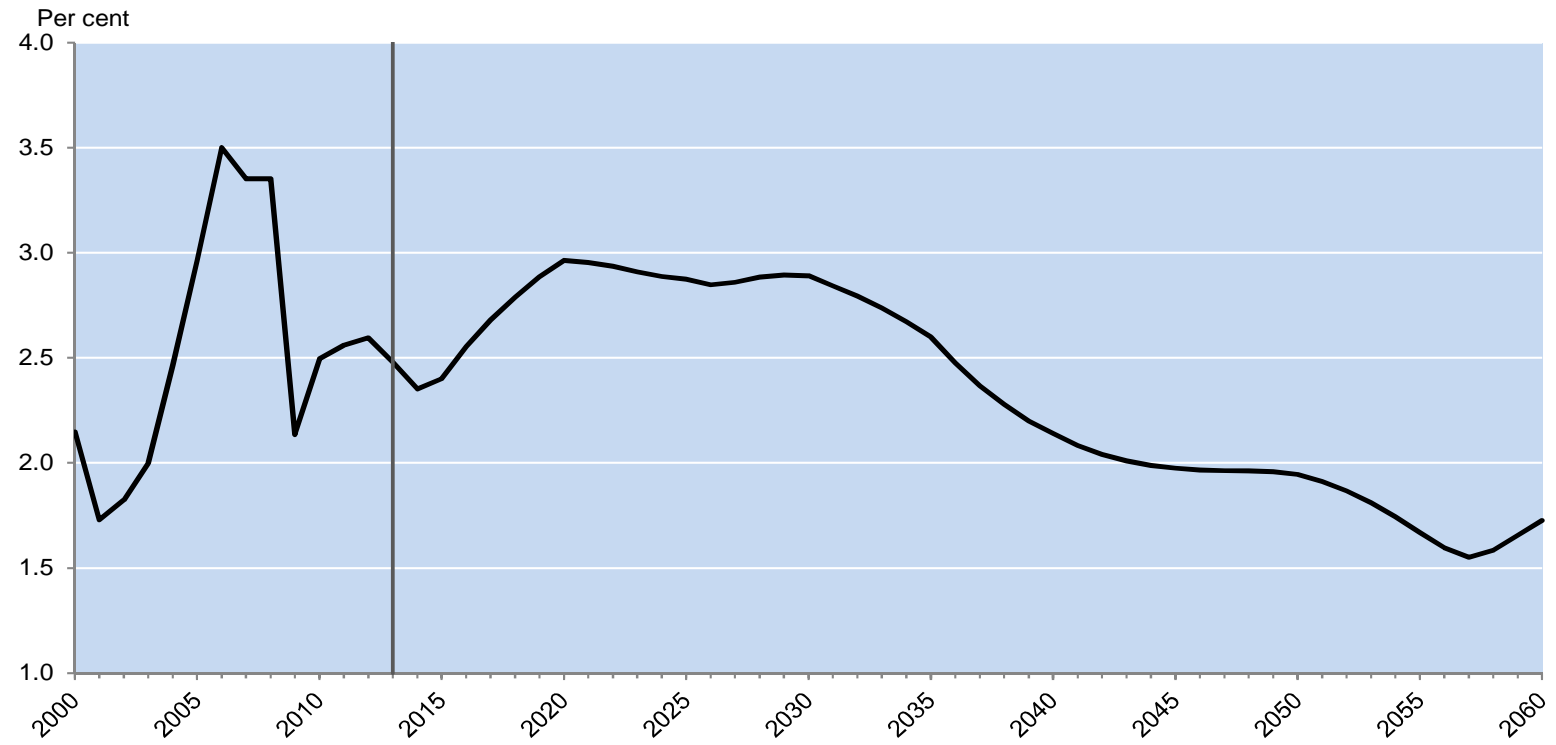

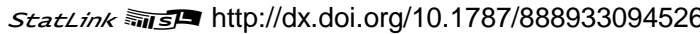

Source: OECD Economic Outlook 95 long-term database.

9
Given the important role that demographic factors play in determining current accounts, changing migration flows could also have an important impact going forward.

Fiscal consolidation takes time to significantly dampen imbalances, with much of the effect occurring after 2020. 
23. Continued increases in inequality may have repercussions for savings and investment patterns, affecting global imbalances. The potentially widespread and large increases in inequality highlighted in the central scenario could lead to increased savings, as saving rates tend to be higher for high-income households than for low-income ones (Dynan et al., 2004). To the extent that capital is fully mobile across borders, countries with fast-rising inequality would tend to experience improvements in current accounts. There are some indications that OECD countries that experienced large increases in earning inequality also tended to improve their current account positions. But continued increases in income inequality could contribute to building up new financial imbalances. It has been argued that rising inequality could thus be one factor behind falling real interest rates in many countries over the last decades, reflecting rising ex ante excess saving relative to investment demand (Rajan, 2010). To allocate rising savings towards borrowers, credit growth and financial intermediation grew, which together with high leverage and lax lending standards may have contributed to the recent financial crisis (Kumhof and Rancière, 2010). These effects would have to be weighed against factors pointing in the opposite direction, like decreasing global savings due to ageing and lower precautionary saving in large emerging markets as social expenditures in these countries rise.

\subsection{Tensions and risks for the global outlook until 2060 \\ 2.6.1 Prospects for future growth in multifactor productivity are uncertain}

24. Under the central scenario, multifactor productivity growth is expected to contribute, on average, $75 \%$ of the growth in GDP per capita in OECD and major non-member economies in the period to 2060 (Figure 2, panel A). While the pace of MFP growth may moderate over the forecast horizon, the trend growth rate in most countries is expected to be high compared with recent history. Relatively strong MFP growth reflects strong investment in knowledge-based capital (KBC), such as R\&D, organisational knowhow, databases, design, brands and various forms of intellectual property, as well as pro-competition reforms in countries where regulations are relatively restrictive (Box 3) and the continued dissemination of new discoveries made at the technological frontier. Nevertheless, the pace of future MFP growth is highly uncertain, in large part due to uncertainty in the future growth rate of the stock of frontier ideas (Fernald and Jones, 2014). Indeed, there are strongly contrasting views on the most likely pace of future frontier growth, with much of the discussion revolving around the potential of ICT in transforming economies:

- An optimistic view, positing that once organisational systems and processes are redesigned to exploit the full potential of ICT there will be cascading growth in complementary innovations. This would drive the technological frontier forward at a fast pace relative to history (e.g. Brynjolfson and McAfee, 2011). ${ }^{11}$ As support for this theory, advocates point to the significant lag between the discovery of other general purpose technologies in history (e.g. electricity) and the burst of innovation that their discovery facilitated (e.g. the light bulb or the telephone).

- A pessimistic view, that argues that the main impact of the ICT revolution has withered and future inventions that derive from ICT are unlikely to fundamentally change trend productivity (e.g. Gordon, 2012). Such a view is consistent with the recent slowdown in productivity in many OECD countries, though it is difficult to differentiate between the cyclical impact of the financial crisis and changes in the pace of discovery at the technological frontier.

25. Irrespective of which scenario unfolds, countries that have a high stock of knowledge-based assets are likely to be better able to adapt to changes in the pace of frontier growth. As argued in the next section, the accumulation of such assets can be encouraged by appropriate government policies.

26. Rising trade integration will likely also increase the pace of international technology diffusion, thus raising multifactor productivity growth. These dynamic effects are likely to be particularly important for countries that are far from the technology frontier. As these effects are not factored into the baseline, they thus pose an upside risk to growth. 


\subsubsection{Rising demand for highly-educated workers will constitute a challenge for tertiary education systems, with consequences for growth and equity}

27. While average levels of educational attainment will continue to rise, increases are set to slow in the central scenario. ${ }^{12}$ This expected slowdown in the growth of human capital is consistent with roughly constant returns to investment in education (Johansson et al., 2013). As discussed in section 2.3, earning inequalities may rise in the future mainly due to the increased knowledge orientation of the global economy, raising incentives to invest in education. This suggests that demand for education could grow faster than in the central scenario.

28. OECD analysis based on an estimated demand and supply model for tertiary education (see Braconier, 2014 for details) suggest that if demand for tertiary education reacts to earning differentials and incomes in the same way as during the last two decades, it may indeed grow faster than in the central scenario in most OECD countries (Figure 8). The question then is whether and under which policy conditions supply of tertiary education can expand to meet this higher demand. If it does, skill upgrading and growth could be boosted and increases in inequality mitigated compared to the central scenario. ${ }^{13}$ If it does not, then growth will be lower and inequalities higher.

\section{Box 4. Using models to identify risks, tensions and consequences of alternative scenarios}

\section{Identifying risks and tensions}

Outputs from models are also used to question exogenous assumptions and illustrate potential feedback mechanisms (dashed arrows in Figure) in order to question exogenous assumptions in the central scenario, so as to highlight risks and tensions:

- The rising trade intensities that MIRAGE-e predicts could spur faster productivity growth than in the baseline, due to the role of trade intensity as a driver of technological progress in the long term growth model. Growth could also be higher due to a long ICT wave while, in contrast, a slowdown in frontier productivity growth would have significant negative consequences for global growth.

- Demographic projections embodied in the central scenario may turn out to be too optimistic once endogenous factors driving economic migration are properly accounted for. A model predicting international stocks of migrants (described in Westmore, 2014) suggests that due to the income convergence between traditional host and home countries taking place in the central scenario, migration flows into the OECD may dry up or even reverse.

- Projected emissions of greenhouse gases, and subsequent increases in temperatures, could feed back to economic activity (GDP) and specialization patterns, indicating that GDP could be lower than in the central scenario in the long run. Extensions of the ENVgrowth and ENV-linkages models to incorporate this mechanism in a model (described in Braconier and Dellink, 2014) translates temperature changes into weather consequences and weather changes into economic damages (e.g. in tourism and agriculture).

- Demand and supply for tertiary education may behave differently than in the central scenario, due to developments in returns to education. A model for tertiary education described in Braconier, 2014 - indicates that demand for tertiary graduations may rise faster than in the central scenario due to increasing GDP per capita and relative earning differentials. This suggests that higher growth and lower earning inequality than in the central scenario could be achieved if supply (funding) can be provided.

12 In the very long run (beyond 2100), mean years of schooling are assumed to converge to 18 years.

13 Note however that a significant part of the rise in earning dispersion relates to within skill category and within occupations. 


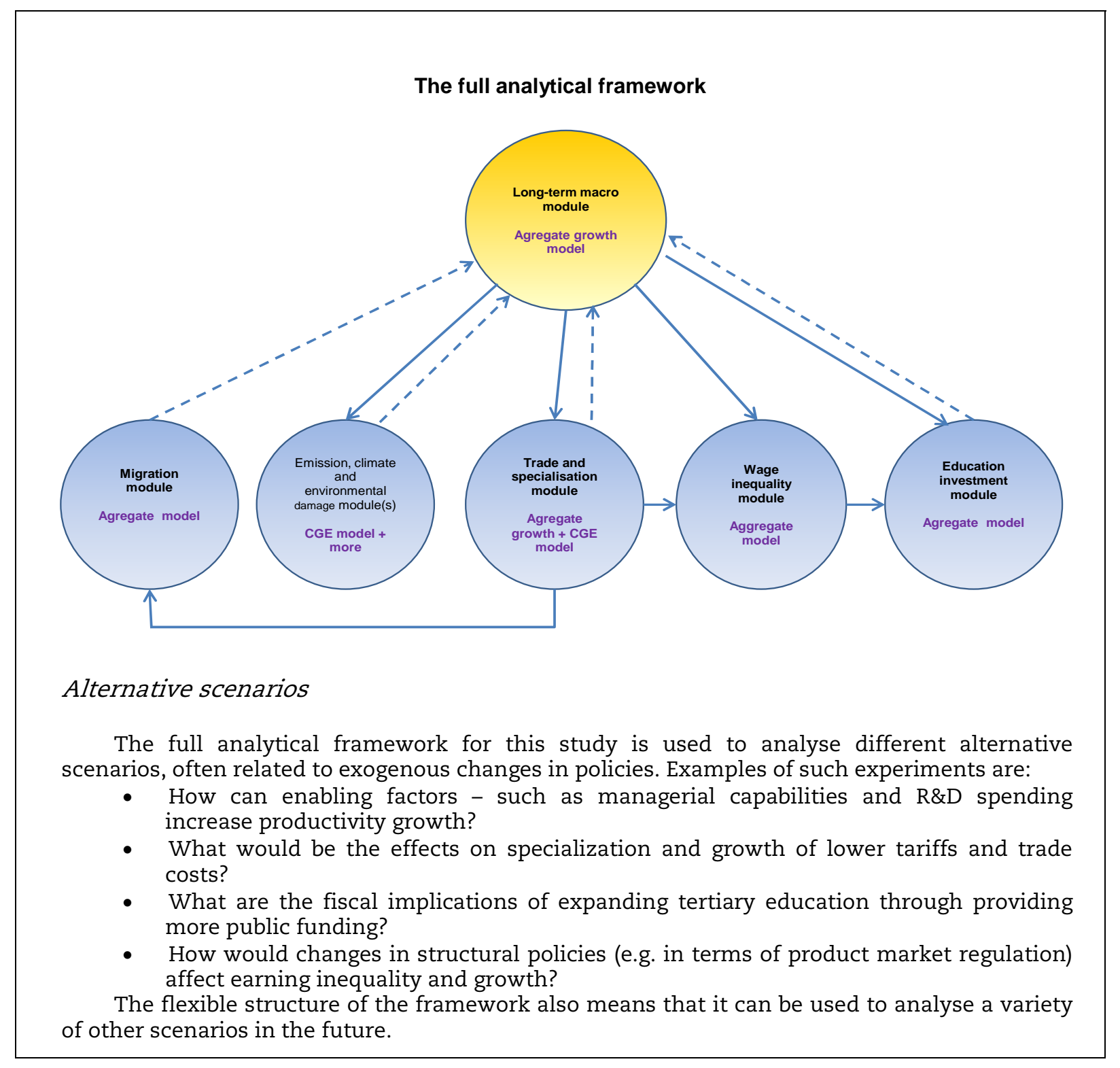




\section{Figure 8. Increase in demand for tertiary graduations 2009-2060 in central and alternative scenario}

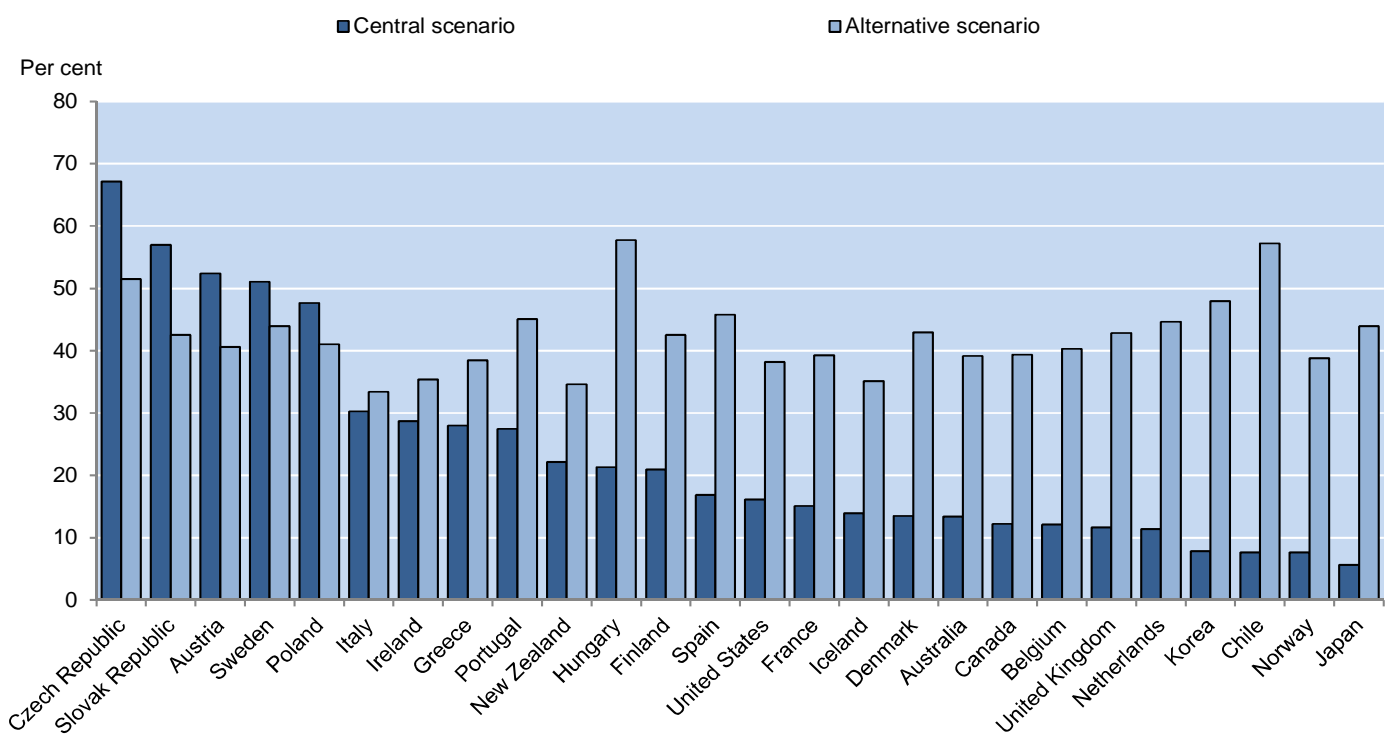

StatLink הins http://dx.doi.org/10.1787/888933094545

Note: Central scenario refers to the implied increase in tertiary graduations between 2009 and 2060 needed to generate the share of tertiary graduates in the labour force assumed in the central scenario (see Braconier, 2014 for details). Alternative scenario refers to scenario 1 in Braconier, 2014, where demand for graduations is derived from an estimated econometric model. Based on an estimated supply model, the scenario assumes that real household expenditures per enrolled student are constant while public funding is assumed to adjust to ensure that supply will equal demand.

Source: OECD calculations.

2.6.3 Income convergence between OECD countries and developing economies may dampen workrelated migration flows, exacerbating labour shortages in the OECD

29. The UN and Eurostat population projections, which the central scenario is based on, anticipate international migration will alleviate some of the natural decline in the working age population of the OECD (Figure 9, Panel A). However, the expected (if partial) income and wage convergence between OECD countries and emerging economies will lower the economic incentives for migration over the next 50 years. As suggested by the analysis in Westmore, 2014, these diminished incentives may significantly impact flows of immigration into OECD countries so that the OECD may in fact experience net emigration of economic migrants between 2010 and 2060 (Figure 9, Panel B; Westmore, 2014). 


\section{Figure 9. Population and migration, 2010-2060}

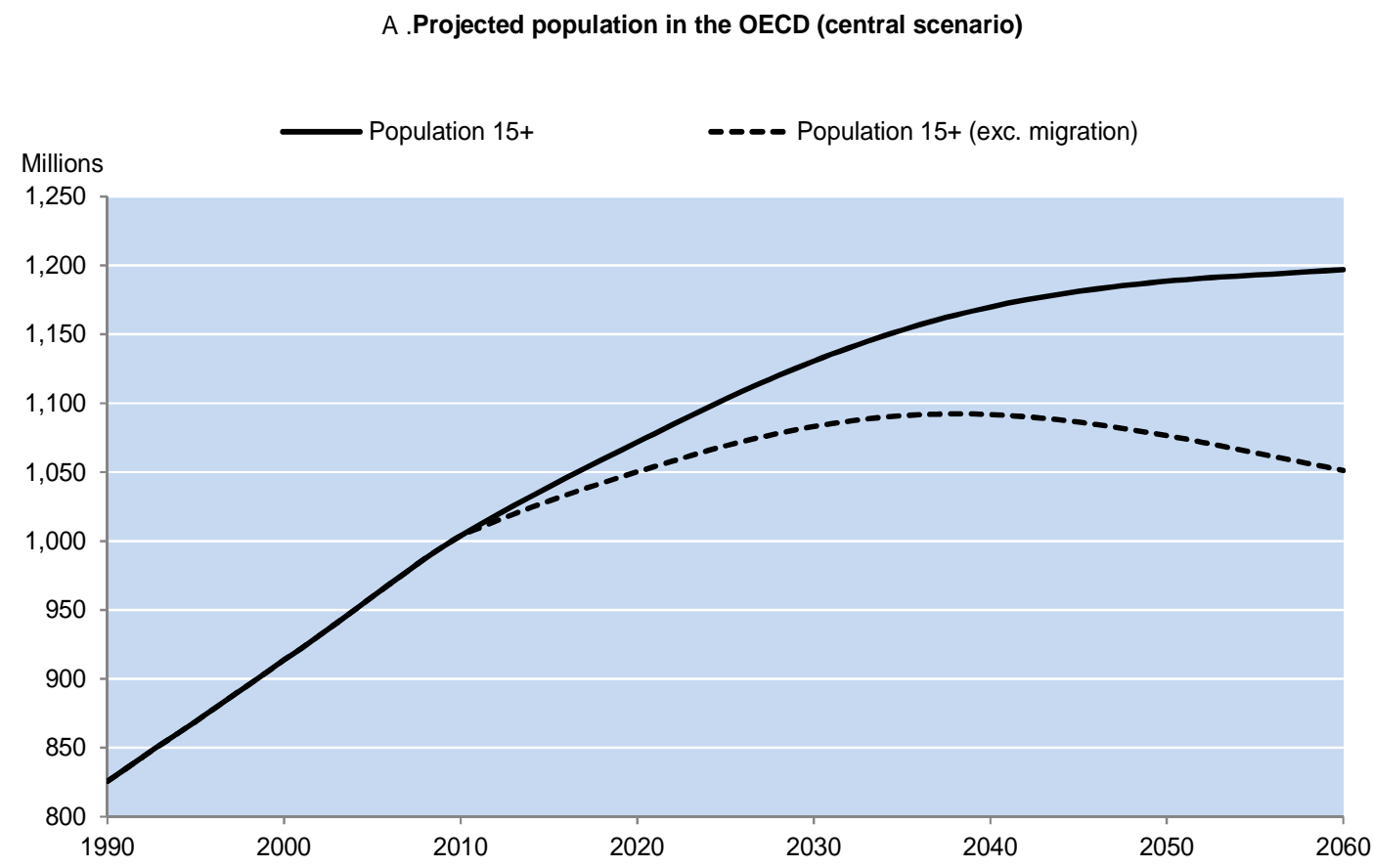

B. Change in migration between 2010 and 2060

Comparison of central scenario projections with model-based projections

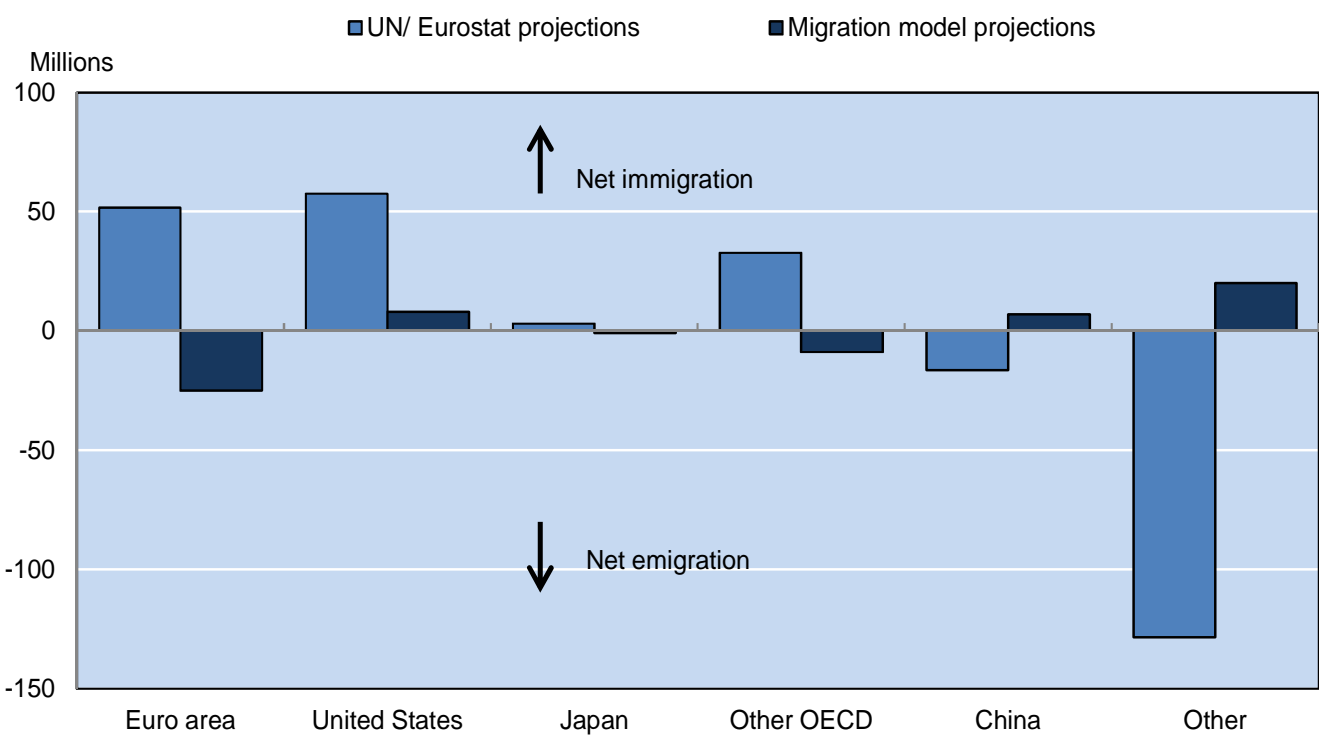

StatLink : जils $\mathrm{http}: / / \mathrm{dx}$. doi.org/10.1787/888933094564

Note: The "Migration model" projections in Panel B are obtained by combining; i) the estimated sensitivity of migrant stocks to changes in relative wage differentials (i.e. destination to origin country) from the migration model, with; ii) bilateral migration stock data in 2000 for 195 country pairs and; iii) wage projections over the period to 2060 from the central scenario. From this, the estimated change in migrant stocks to 2060 due to wage movements (holding all else constant) is obtained at the country level before being aggregated into the regions presented in Panel B. See Westmore, 2014 for further details.

Source: UN, Eurostat, OECD estimates. 
30. The direction and the composition of these alternative migration flows differ across regions. According to the analysis in Westmore, 2014, some developed regions - such as the US - would continue to experience a net inflow of migrants, whereas others - such as the euro area - may experience a net outflow over the period to 2060, as wage growth in traditional "source" countries is expected to be relatively fast. The impact on the labour force and GDP in such regions could be significant. For example, estimates suggest that the modelled decline in migrants may lower the potential labour force by as much as $20 \%$ in the euro area and 15\% in the United States by 2060 relative to the central scenario (Figure 10).

Figure 10. Potential labour force with modelled migration flows

Per cent change in 2060 relative to central scenario

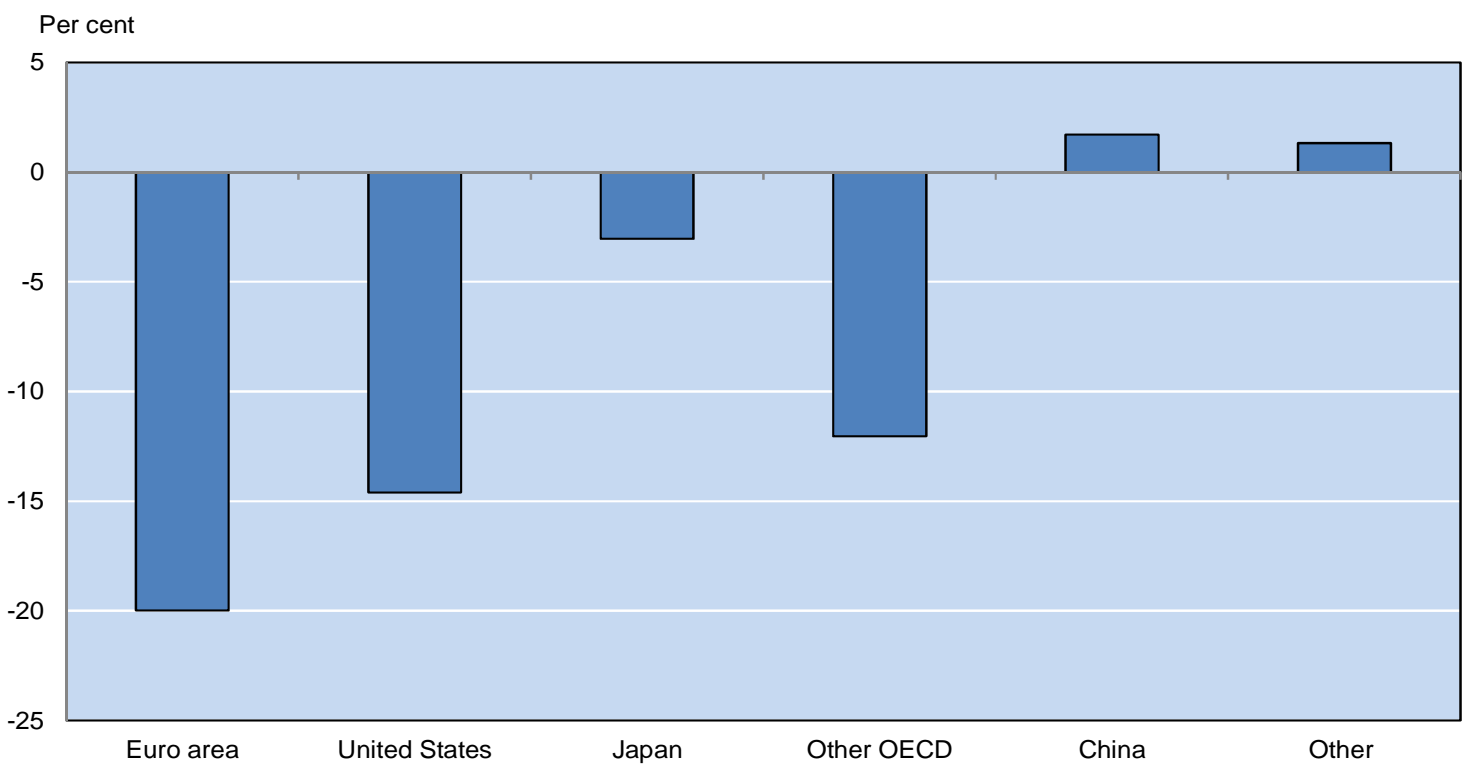

StatLink 젶ㄴ http://dx.doi.org/10.1787/888933094583

Note: The potential labour projections at 2060 are obtained by assuming the same time-varying country-specific age distribution of net migrants as the UN/Eurostat projections. The potential labour stocks at 2060 are estimated by calculating the number of immigrants in each country at 2060 that are above 15 years of age and holding the labour force participation rate and the natural rate of unemployment constant at the value assumed in the central scenario. The potential labour projections are calculated for all countries included in the long-term scenarios (Johansson et al., 2012) apart from Estonia and Saudi Arabia that are excluded due to poor data quality for the migrant age profile. The country level estimates are then aggregated into the regions presented in Figure 4.

Source: OECD estimates.

\subsubsection{Costs related to ageing, health and education will increase fiscal pressures, and a drying up of migration could make things worse}

31. As already mentioned, the scale of the needed structural and fiscal reforms to stabilise public debt at $60 \%$ of GDP in the central scenario is substantial. To illustrate this, Figure 11 shows fiscal challenges that OECD countries may face from health, pension and education spending - on top of the fiscal adjustments that are needed to reach the $60 \%$ of GDP gross debt target. Clearly, these additional fiscal pressures pose a major downside risk to the fiscal position embedded in the central scenario for OECD countries. 


\section{Figure 11. Fiscal pressures in the OECD area are strong}

Fiscal pressures including health, pension and tertiary education spending, 2060

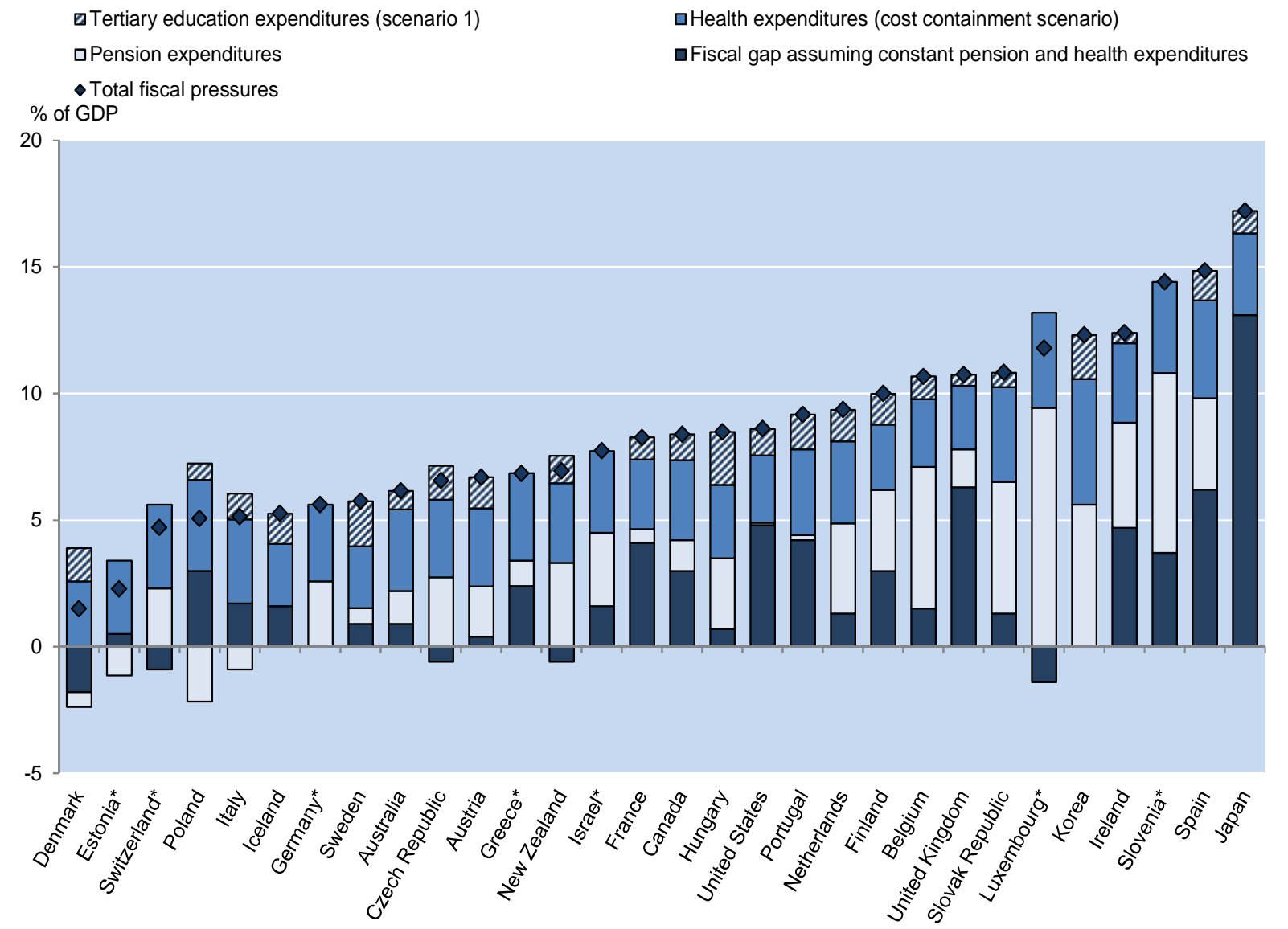

StatLink 젶ㄴ http://dx.doi.org/10.1787/888933094602

* Tertiary education spending projections not available.

Source: OECD Economic Outlook 95 long-term database, OECD (2013i), de la Maisonneuve and Oliveira-Martins (2013), Fall et al (2014).; OECD calculations.

32. The fiscal challenges that emerging economies face are to a large extent similar to those in OECD countries. Demographic pressures are building up in many countries - like China and Brazil - which in combination with low coverage and replacement rates will add pressure to retirement funding (Fall and Bloch, 2014). Similarly, de la Maisonneuve and Oliveira Martins (2013) estimate that even in the cost containment scenario, the BRIICS total health and long-term care expenditure will increase from $2.5 \%$ currently to above 5\% of GDP in 2060. Finally, the fiscal pressures from expanding public education systems are likely to be larger in emerging economies than in the OECD, reflecting the need to build up primary and secondary education together with a rapid expansion of tertiary education. 


\subsection{5 before 2060

33. Environmental pressures associated with business as usual growth are expected to continue to build (OECD, 2012b). By 2050, terrestrial biodiversity is projected to decline by a further $10 \%, 40 \%$ of the world's population is projected to be living in areas of high water scarcity, premature deaths linked to airborne particulate matter are projected to double, and disruptive climate change is likely to be locked in as a result of a large increase in greenhouse gas emissions.

34. Of these trends, rising greenhouse gas concentrations pose the most comprehensively global risk to economic output. Without dramatic changes in the carbon intensity of global energy production and consumption, economic growth will lead to constantly rising greenhouse gas (GHG) emissions and increasing concentration of such gases in the atmosphere. This will significantly increase the risk of costly climatic change as well as exacerbating other environmental pressures. Contributions from nonOECD countries will rise rapidly as their share of world economic output grows (Figure 12). While the full effects of unfettered GHG emissions are expected to produce their largest economic damages after 2060, rising global temperatures may start to affect GDP earlier (Braconier, H. and R. Dellink, 2014).

\section{Figure 12. Total greenhouse gas emissions, 2010 and 2060}

(Million tonnes, $\mathrm{CO}_{2}$ equivalent)

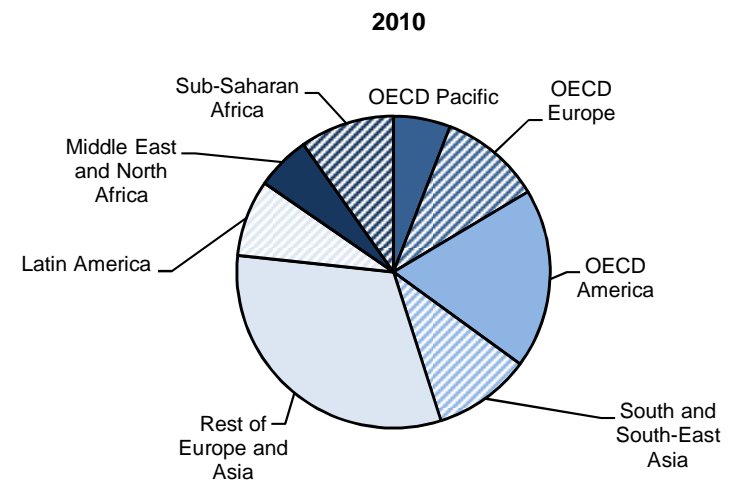

Total:

48700 million tonnes

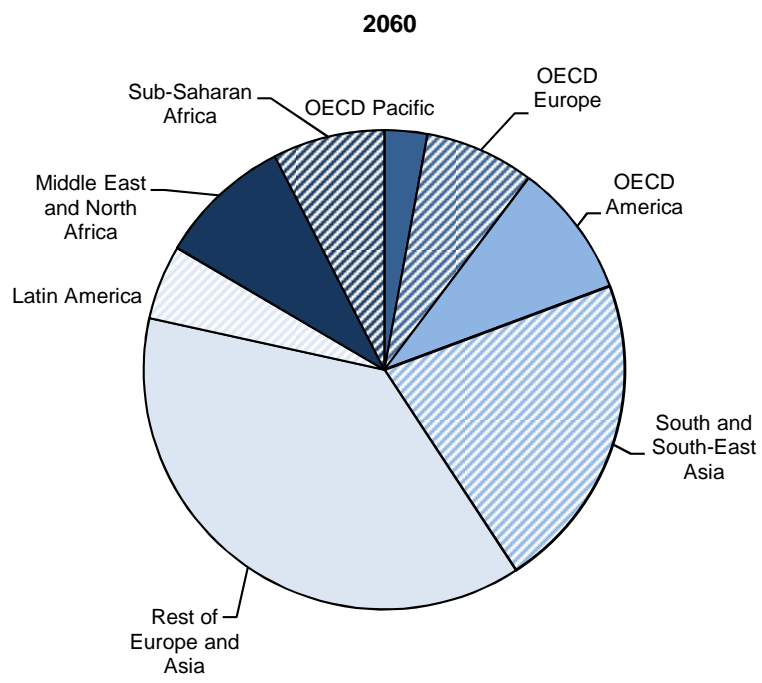

99500 million tonnes

Note: OECD Pacific includes Australia, Japan, Korea and New Zealand, OECD America includes Canada, Chili, Mexico and United states. Latin America excludes Chili and Mexico.

Source: OECD calculations. 
35. The central scenario does not reflect the economic damages from climate change, which will entail a significant pressure on global output and living conditions in the long run. New OECD projections (see Braconier, H. and R. Dellink, 2014), suggest that world GDP in 2060 may be lowered by between $0.7 \%$ and $2.5 \%$ due to the effects from a selected number of climate change impacts (Figure 13, panel A). Climate change will affect economic performance through a number of channels. On a global level, falling agricultural productivity, and capital and land losses related to sea level rise, are likely to be among the main contributors to climate change-related impacts on GDP by 2060 (Figure 13, panel B).

36. The strength of the impact depends on geographic and climatic conditions as well as the prevailing specialisation patterns. Therefore, the extent and timing of climate change damage is likely to differ substantially across countries and regions (Figure 13, panel C). Regions that already experience high temperature variability, have large agricultural sectors and are vulnerable to sea level rise may be worst hit, with damages in South and South-East Asia perhaps amounting to more than 5\% of GDP in 2060. In more temperate regions benefits may initially outweigh losses through higher agricultural productivity, improved terms of trade and, in some cases, stronger net demand for tourist services. Nevertheless, these benefits may not be sustained. 


\section{Figure 13. Climate change impact on GDP}

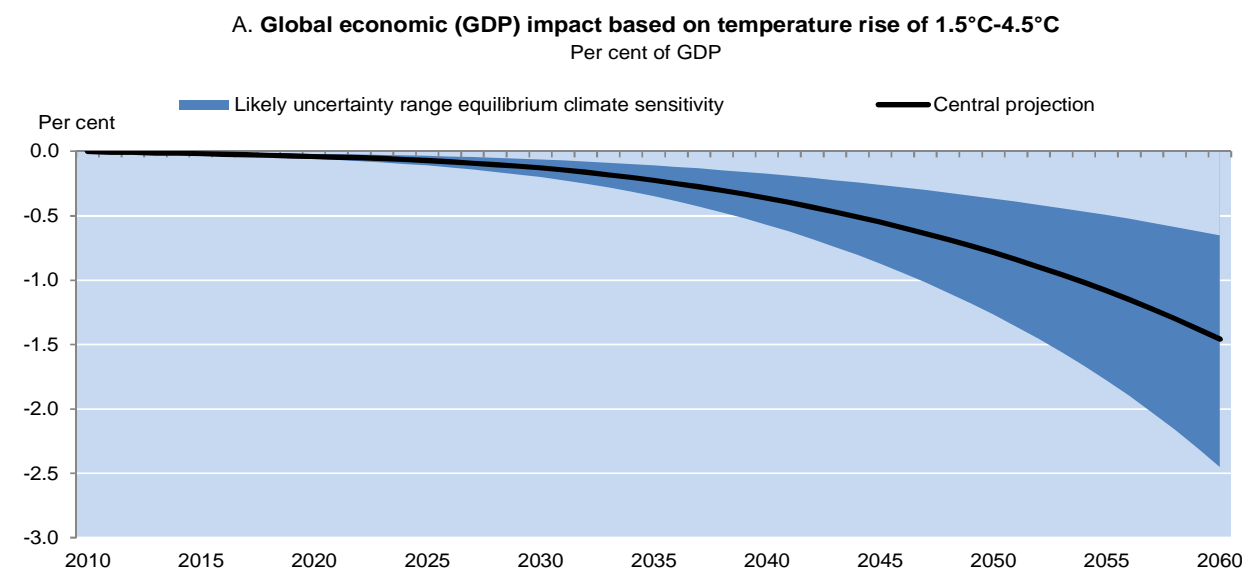

B. Shares of global economic (GDP) impact of climate change (central projection)

World damages 2035

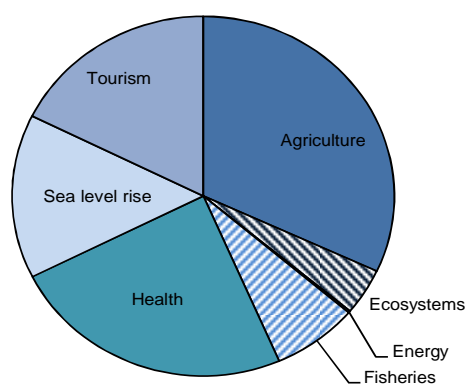

World damages 2060

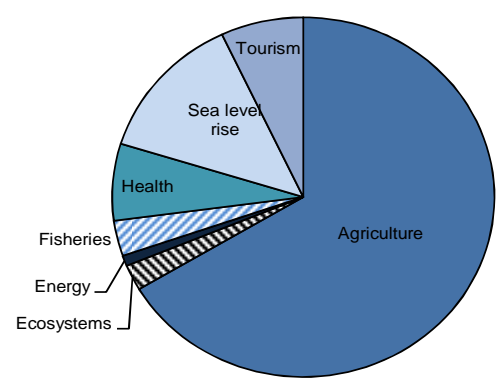

C. Regional economic (GDP) impact of climate change to 2060 (central projection) Per cent of GDP

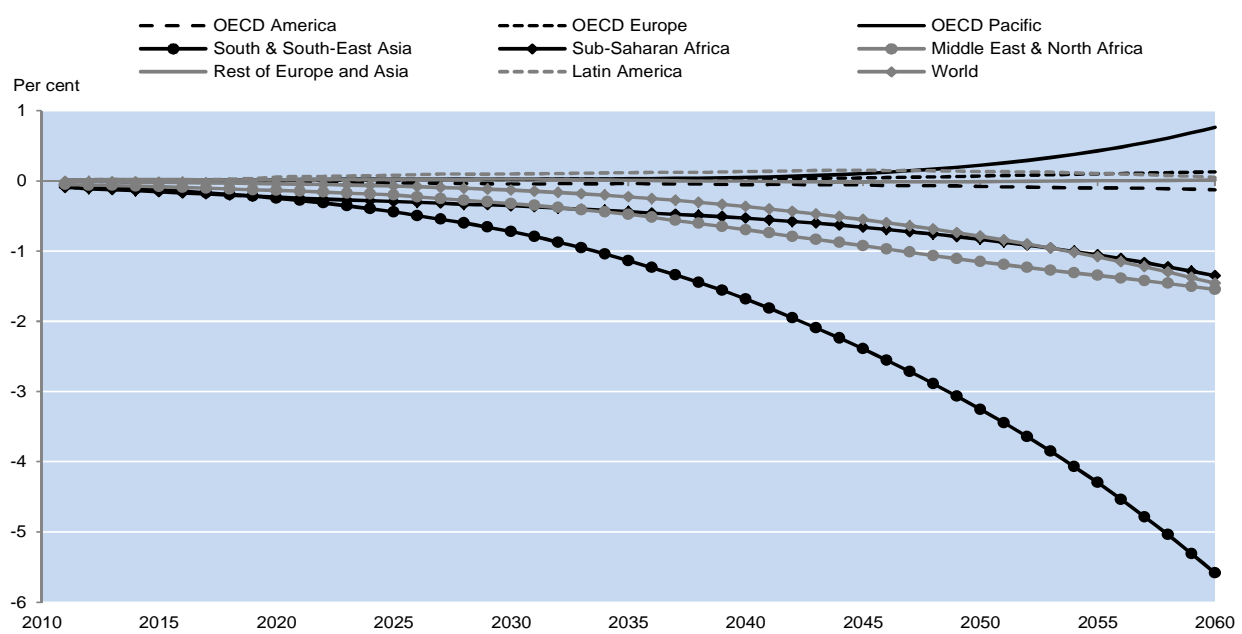

StatLink त्ञाs http://dx.doi.org/10.1787/888933094640

Note: Agriculture refers to changes in crop yields. Ecosystems relate to willingness to pay to avoid impact, while energy shows estimated changes in demand for cooling and heating. Fisheries refer to changes in catch, while health captures changes in labour productivity and in demand for healthcare due to certain illnesses or pathologies. Sea level rise denotes damages related to coastal land losses and damages to capital.

Source: OECD calculations using the ENV-Linkages model. 


\section{Box 5. Main policy conclusions on how to strengthen growth}

- $\quad$ Further agreements on trade liberalization could boost growth, especially in some emerging economies. Global benefits are larger from multilateral than regional trade liberalization. Effects on wage differentials would likely be small.

- $\quad$ Rising international connectedness in general terms and specifically the important role MNEs play in global business R\&D mean that the benefits from public basic research and support to private R\&D will become more global, weakening incentives for individual governments to support these activities. Global mechanisms to fund and support basic research as well as coordination in tax treatment of R\&D incentives may be warranted.

- Intellectual property rights (IPRs) are crucial for investment in some types of knowledge based assets, but could also hinder innovation in some areas (such as ICT). Reviewing and coordinating internationally IPR approaches could support growth.

- Some enabling factors, such as private R\&D and high-quality management, enhance capabilities to absorb and deploy effectively new technologies, thus supporting productivity growth.

- Fostering competition at home and in international markets, also via closer cooperation among competition authorities, complements IPR and stimulates the build-up of growthenabling factors.

- $\quad$ There is little evidence that the pace of structural change will rise over the coming 50 years. However, an ageing workforce will likely be less able to adapt to structural change, risking to increase mismatches in the labour market and slow structural change. This may require a shift in the focus of labour market policies from search activities towards work incentives and retraining.

- Longevity adjustment in retirement ages will be needed to mitigate negative labour supply and growth effects from ageing.

- $\quad$ Migration and labour supply can be boosted by a combination of labour and product market flexibility and labour-migration friendly policies.

- $\quad$ Private and social returns to education are likely to increase as earning differentials widen and working-lives become longer and will lead to rising demand for tertiary education. Meeting this demand can spur growth and support equity, but tuitions should contribute a larger share of total costs of tertiary education. In this context, lending schemes to finance tuitions to address liquidity constraints and share rising idiosyncratic earning risk are desirable.

- As working lives lengthens in response to rising longevity, strategies and funding for lifelong learning will have to be strengthened. Given lower cross-country mobility among older workers, the scope for public funding is wider than for younger tertiary students.

37. In the central scenario outlined in section 2 growth is set to slow in both OECD countries and nonmember economies, with tensions and risks on both the up- and downside. This section deals with policies to support stronger growth, the trade-offs and spillovers these will entail, and how trade-offs and policy recommendations may evolve over the coming 50 years. 
3.1 A more integrated global trading system can boost growth but would increase interdependence and pressures to adjust structural policies

3.1.1 Further trade liberalisation and improved framework policies would increase trade and promote growth

38. Openness to trade is associated with higher incomes and growth (see e.g. Bouis et al., 2011). These benefits are transmitted through several channels: shifting production from low to high productive locations; relocation of factors of production towards sectors and firms with high productivity; and rising incomes due to an increase in market size that supports more specialisation, faster technology diffusion and stronger incentives to invest in 'non-rival' assets (Rivera-Batiz and Romer, 1991; Ventura, 2005). The former two effects include mostly static gains from international trade in goods, services and factors of production, while the latter entails dynamic growth effects. As shown in Johansson and Olaberría, 2014, significant static and dynamic efficiency gains - especially for developing countries - could be reaped through further multilateral trade liberalisation, while global welfare gains from regional agreements are much more limited due to trade diversion (Box 6) ${ }^{14}$ While fostering multilateral trade liberalisation has proved difficult in the recent past and regional arrangements have been frequent, the former should remain priority due these larger benefits and despite the practical challenges of seeing through such reforms in a multipolar world. 


\section{Box 6. The economic impact of further multilateral trade liberalisation}

Recent OECD work (Johansson and Olaberría, 2014) illustrates the potential effects from further multilateral and regional trade liberalisation.. The multilateral scenario assumes that tariffs on goods are reduced by $50 \%$ relative to baseline, while transaction costs are reduced by $25 \%$. Significant reductions of regulatory barriers are implemented, while agricultural support is reduced by $50 \%$ in the European Union, the United States, Japan, Korea and in EFTA countries.

As a consequence of these liberalisation policies, world trade could increase by $15 \%$, in 2060. Effects on specialisation patterns would include a reallocation towards more service production in emerging economies. Economic benefits from multilateral liberalisation range from $0,5 \%$ of GDP for some OECD economies to almost $8 \%$ for India (See figure). Skilled wage premia will tend to increase.

\section{Effects of further trade liberalisation on GDP and skill premia by 2060}

Change relative to central scenario

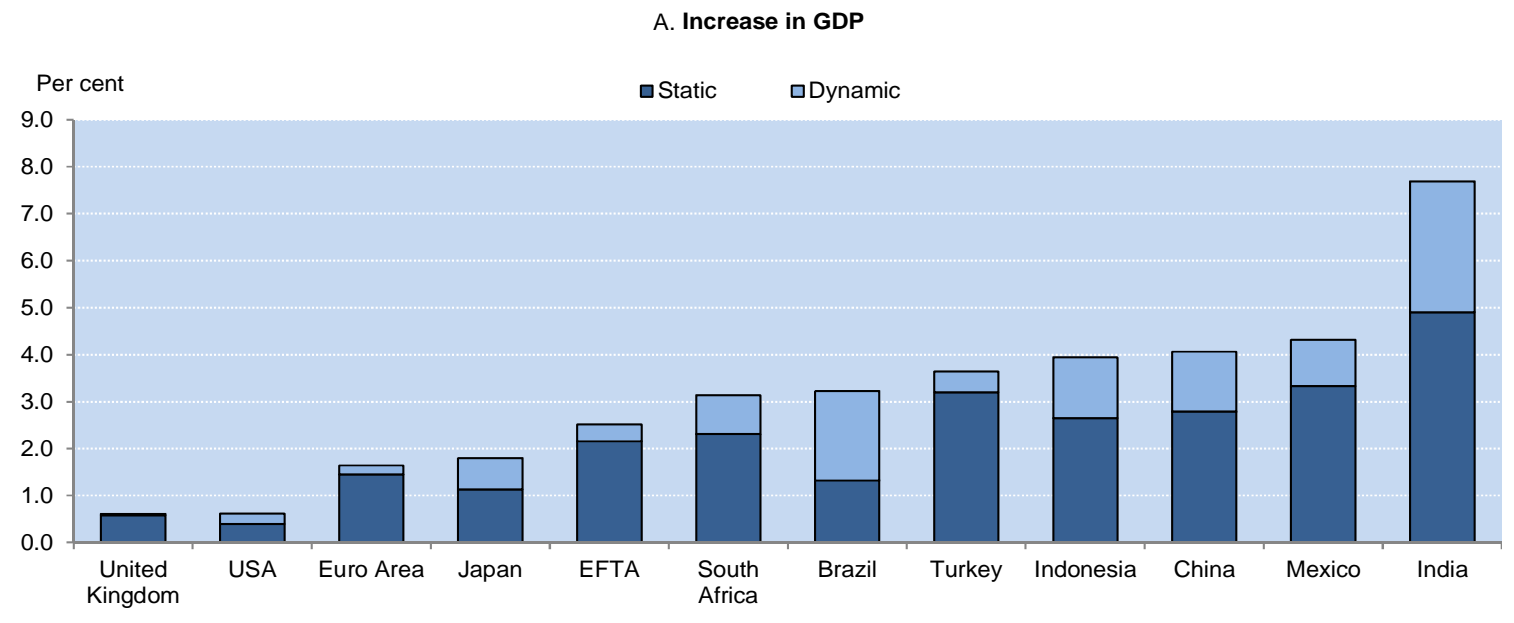

B. Increase in skill premia (wage skilled/unskilled worker)

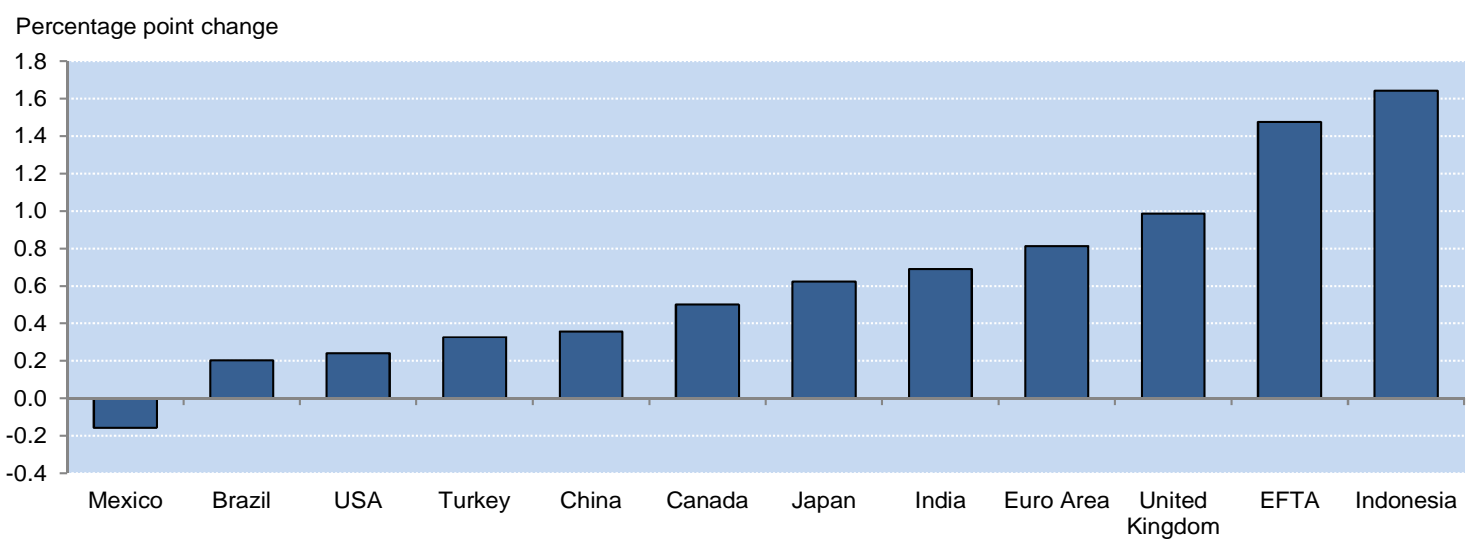

Note: Based on "Multilateral" scenario in Johansson and Olaberría, 2014, relative to central scenario.

Source: OECD calculations. 
39. Well-designed framework policies and institutions promote growth by facilitating trade. Trading internationally entails costs and additional risks for firms such as exchange rate uncertainty and increasing potential for infringement of property rights. These costs and risks tend to rise with the complexity of supply chains and with the extent to which intangible assets are part of the production process (Nunn and Trefler, 2013), while they tend to decrease with the quality of institutions of trading partners. A high overall quality of institutions promotes aggregate exports, with a stronger effect on exports in sectors with complex supply chains (Johansson and Olaberría, 2014). Moreover, the positive effects of lowering tariffs are magnified in sectors characterised by long cross-border value-added chains. As the complexity of global supply chains likely will grow, and production increasingly will rely on knowledge-based capital, the benefits of improving framework conditions and lifting trade barriers are likely to increase in the future.

\subsection{2 ... but could also imply negative side effects by increasing earnings inequality and the pace of restructuring}

40. However, reforming framework policies to reap larger benefits from trade can also have negative side-effects on other public policy objectives, which need to be weighed against the benefits and may require countervailing policies:

- $\quad$ Trade financing and the management of exchange rate risk requires access to financial services and a larger financial sector - in terms of credit to GDP - is associated with higher exports especially in sectors with high dependence on external financing (Johansson and Olaberría, 2014). However, higher credit-to-GDP ratios may also entail larger financial risks (Sutherland and Hoeller, 2012) and hamper growth, all other things equal (Cournède, B. and O. Denk, 2014).

- The figure in Box 6 suggests that trade liberalisation may tend to increase both GDP and domestic inequality, suggesting a possible trade-off. The empirical analysis in Braconier, 2014 shows that rising trade exposure is associated with lower labour shares of GDP, suggesting that (more mobile) capital benefits more from globalisation than (less mobile) labour. However, the role of rising international trade in explaining widening earnings and income differentials within countries remains open to dispute and compensating mechanisms, for example in terms of efficient adjustment of the skill composition to changes in relative wages, may explain part of the difference between these analyses. Indeed, most cross-country empirical analyses suggest that rising trade exposure explains little of recent increases in inequality. ${ }^{15}$

- While the overall impact of rising exposure to trade on aggregate wage differentials and employment may be limited, the social costs relating to the restructuring of production along new trade specialisation patterns may be much bigger. Trade reforms lead to reallocation of resources across sectors, occupations and firms as specialisation patterns respond to changes in relative prices. For instance, Levchenko and Zhang (2013) show that if factors of production are immobile across sectors, the integration of China, India and the Central and Eastern European countries into the world trade system may have increased aggregate welfare in the rest of the world by $0.4 \%$, but factor incomes in individual sectors may fall or rise by more than $5 \%$.

41. Dealing with relative wage pressures and needs for structural adjustment due to rising trade integration will thus be important. However, these challenges are not conceptually different from those emanating from changing demand structure or technological change, discussed in section 3.3. Policies to deal with such challenges are analysed in section 4 below.

\subsection{Supporting knowledge-based growth}

42. In the central scenario, growth becomes increasingly dependent on rising multifactor productivity, with the contribution to GDP per capita rising from around $54 \%$ to $88 \%$ in OECD countries between 2010 and 2060 and from 79\% to almost 91\% in non-OECD G20 countries. Knowledge will thus be

15 See e.g. IMF (2007) and OECD (2011). Some studies do however find a larger effect on inequality from trade (See e.g. Autor and Dorn, 2013). 
the main driver of growth in the future and policies geared towards enhancing KBC will be crucial. Two classes of policies are considered in this section: public policies to support knowledge creation, development and absorption of new technologies; and policies that influence the effectiveness with which new technologies are used. Accompanying labour market and distributional policies are discussed next.

\subsubsection{Innovation will become even more global, calling for a review of policies and further cross-country coordination in some areas}

43. Publicly funded research often plays a crucial role in the development of new general purpose technologies, such as the internet (Sheehan and Wyckoff, 2003). Ensuring sufficient funding for public R\&D will therefore be important for future growth and for the transition towards a greener economy given that this will require the development of new technologies. Growing international trade integration and improving communication technologies will spread the benefits of public R\&D further, generating larger positive global spillovers. However, as international knowledge spillovers from government funded R\&D increase, countries will find it more difficult to appropriate the benefits associated with such research. This may lower the willingness of governments to invest in basic R\&D, pointing to potential benefits of international coordination in funding such work.

44. Innovation is becoming increasingly globalised with rapid growth in the scientific capability of some emerging economies and the offshoring of R\&D (Andrews and de Serres, 2012). Given that knowledge based asset growth is partly reliant on the accumulation of mobile resources such as skilled labour and FDI, countries' ability to grow at the pace projected in the central scenario may depend on their ability to attract such resources. This could result in policy competition between countries, for example, through changes in the settings of personal income and corporate tax policies to attract investment and managerial ability. Such a scenario has the potential to harm growth through the emergence of fiscal pressures or excessive reallocation of factors, in which case there could be some benefit from cross-country tax policy coordination.

45. With the anticipated rise in globalisation there may be increasing instances of multinational enterprises using cross-border tax strategies to shift profits generated by KBC across countries (OECD, 2013). This may lead to unintentionally high levels of total tax support for R\&D and place domestic 'stand-alone' firms that perform R\&D at a competitive disadvantage. Recent OECD work highlights the potential benefits of international co-operation to limit unintended tax relief for R\&D stemming from cross-border tax planning (OECD, 2013k) as well as the potential growth benefits of designing R\&D support schemes that do not privilege incumbents vis-à-vis young innovative firms (Andrews and Criscuolo, 2013).

46. As per capita income differences between the OECD and many emerging economies converge and international specialisation patterns change in line with increased global integration, the traditional distinction between innovating advanced economy firms and imitating emerging economy firms is likely to blur further. In this context, views on IPR may converge and international policy co-ordination with respect to IPR protection will grow in importance. ${ }^{16}$ Exploiting opportunities for coordination is increasingly important since intellectual property rights (IPR) regimes will need to be frequently updated to keep pace with technological change. For instance, in some emerging KBC sectors where the innovation process is typically fragmented (e.g. software) the patent system may unduly favour incumbents at the expense of young firms, thus undermining incentives to invest in $\mathrm{KBC}$ and creating a policy dilemma that needs to be addressed. ${ }^{17}$

47. Besides reviewing IPR regimes, further pro-competitive reforms to domestic product market regulations may be another avenue to overcome any barriers to KBC accumulation created by existing patent systems, given that IPR regimes are most effective when they are coupled with pro-competition

16 Effective patent systems are also highly dependent on strong courts and well-designed review mechanisms and may benefit in many emerging economies if stronger institutions develop in line with rising GDP per capita.

For example, the emergence of "patent thickets" - i.e. webs of overlapping IPRs (Shapiro, 2001) - can particularly hamper young firms with little bargaining power through having to pay licensing fees to multiple parties or having production held-up as they try to commercialise new technology (UK IPO, 2011; Cockburn et al., 2009). 
policies (Aghion et al., 2005; Westmore, 2013). But with further globalisation, promoting the accumulation of knowledge based assets through competition is likely to require greater cross-border cooperation between competition authorities. Both the number of cartel cases and the number of mergers involving parties from abroad have risen dramatically since 1990 (OECD, 2013h). In the face of such linkages across jurisdictions, global co-operation between competition authorities - usually on a bilateral basis - has improved. However, existing agreements tend to be based purely on information sharing and do not formally promote co-operation with regard to enforcement. Looking forward, multilateral agreements may be pursued. In addition the development of international standards for authorities acknowledging the decisions of partner jurisdictions or co-ordinating investigations of cross-border competition cases may be needed.

\subsubsection{National policies can raise pay-offs from faster technological change}

48. Through encouraging the accumulation of $\mathrm{KBC}$, more effective competition and innovation policies can also help generate additional investments, for example in skills, capital or organisational change. The ability of organisations to restructure is a key determinant of the extent to which they benefit from new technologies (Pozzi and Schivardi, 2012). For example, in order to extract the maximum benefit from ICT, firms typically need to adopt ICT as part of a "system" of mutually reinforcing organisational changes (Brynjolfsson et al., 1997). Box 6 illustrates how enabling factors - like managerial quality and private sector R\&D - are important for adapting to changes in the pace of growth at the technological frontier. ${ }^{18}$ growth between 1995 and 2004 to superior management practices, which significantly raised the productivity of ICT capital in the United States. The key role of management skills for the transmission of frontier technologies is supported by the empirical analysis presented in Annex 2. 


\section{Box 7. Enabling factors impact on growth}

Any increase in global integration will raise the sensitivity of growth prospects to developments at the technological frontier. Irrespective of the pace of frontier growth, the presence of enabling factors - like managerial quality and private sector R\&D - will be increasingly crucial in aiding countries to adjust (Andrews and Westmore, 2014). The first figure below provides an example of how a country's ability to benefit in the event of a positive shock to growth of frontier technologies (with an annual growth rate of $1.8 \%$ instead of the $1.3 \%$ assumed in the central scenario) is affected by the quality of managerial capital. Government policies that encourage strong management practices include encouraging greater market discipline through reductions in PMR (Bloom and Van Reenen, 2010).

\section{Additional GDP per capita gains from a positive shock to frontier growth due to managerial quality}

Increase in GDP per capita 2060

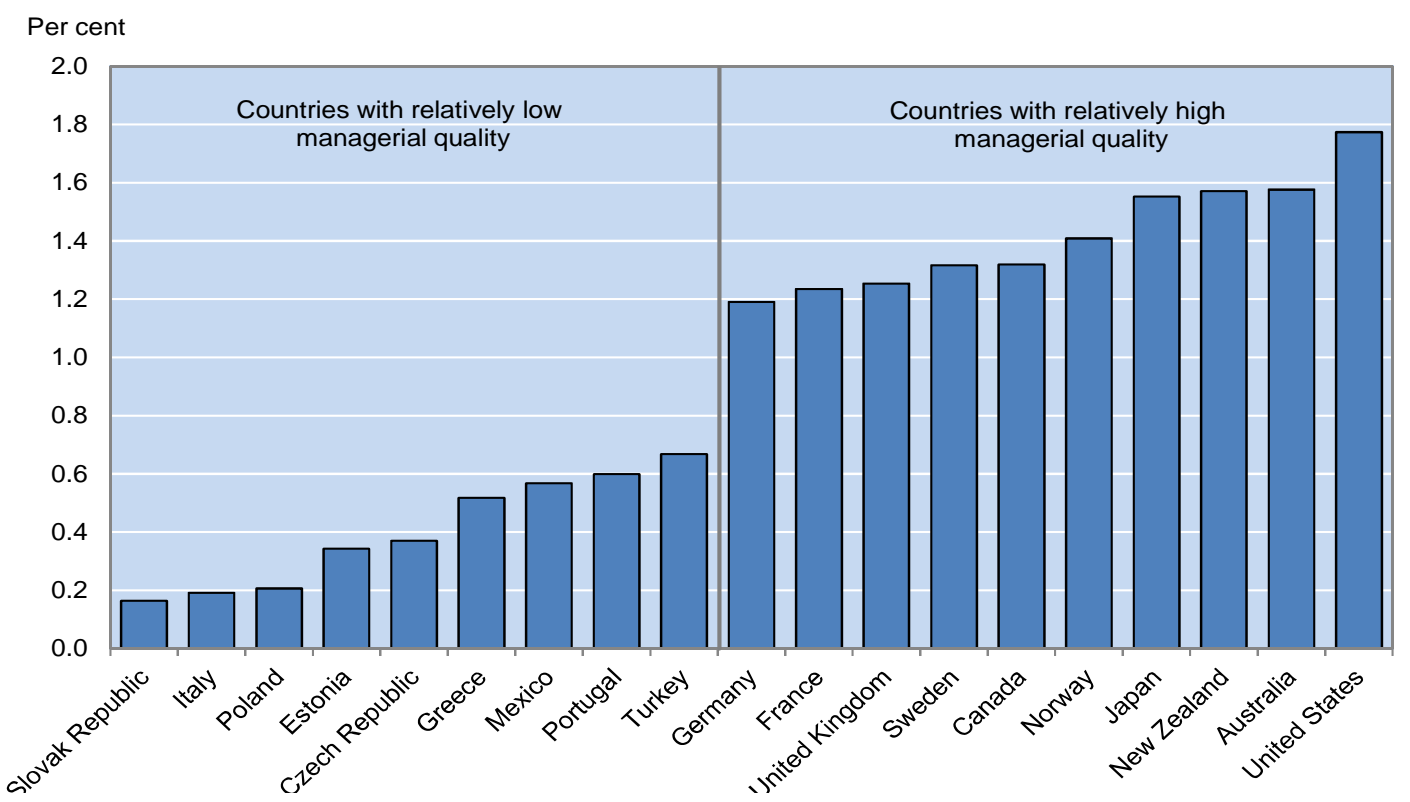

Note: The long-run growth model is re-specified to reflect the new OECD evidence that suggests that countries will converge more rapidly to the long-run steady state MFP level when managerial quality is relatively high (see Andrews and Westmore, 2014). The above graph shows the additional effect on GDP per capita from the "high frontier growth" scenario when the respecified model is used (relative to the results from the base specification). For example, the figure indicates that re specifying the model to allow for managerial quality gives no boost to GDP per capita in Hungary at 2060 under the high growth scenario. In contrast, the re-specification results in 1.8\% higher GDP per capita in the US at 2060 relative to the case when the high frontier growth scenario is run using the base specification of the model.

Source: OECD estimates.

A country's ability to benefit from new discoveries is also linked to the extent of domestic R\&D. For instance, Griffith et al., (2002) argue that higher R\&D spending produces productivity benefits through two different channels (the so-called "two faces" of R\&D). The first channel works through stimulating innovation and the second through better enabling the imitation of others' discoveries and the absorption of foreign technologies. Thus, countries with high business R\&D spending (such as Japan, Switzerland and Sweden) may expect to benefit more from a positive technological shock than countries such as Hungary and the Slovak Republic (See second figure below). As already mentioned, a number of structural policies may be important in 
encouraging KBC investment, including business R\&D. However, innovation-specific policies, such as R\&D tax incentives and government direct support, are also associated with higher business R\&D spending (Westmore, 2013).

Given these channels are not incorporated in the long-run growth model, a further implication of this analysis is that the central scenario may underestimate GDP per capita in countries with high absorptive capacity. For example, on average, countries with high managerial quality and high business R\&D (that is, those that appear in the right hand side of the first and second figures) may experience an additional increase in GDP per capita at 2060 of $1 \%$ and $2 \%$ respectively when the role of these enabling factors is taken into account.

\section{Additional GDP per capita gains from a positive shock to frontier growth due to business R\&D}

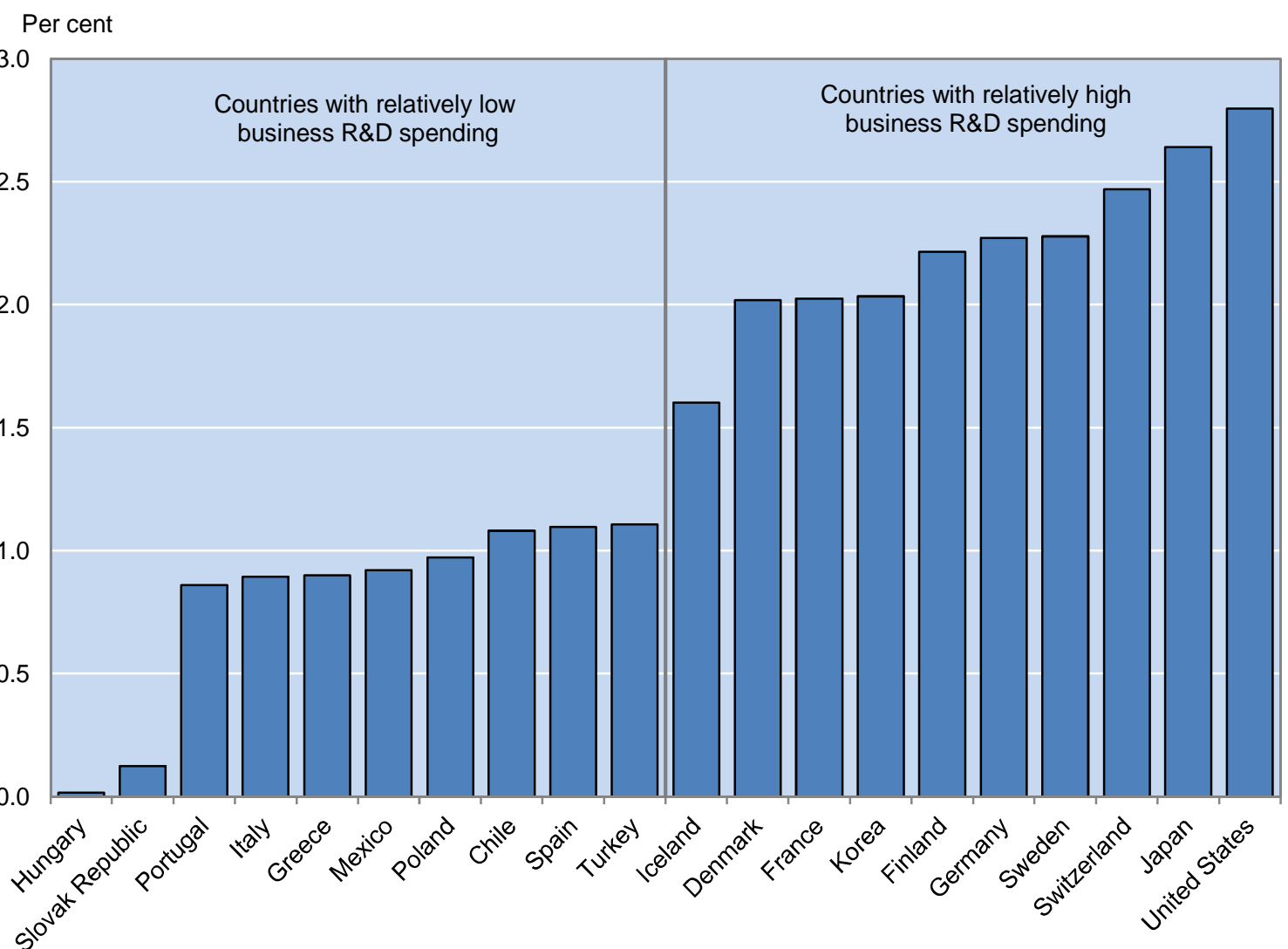

Note: Evidence suggests that countries will converge more rapidly to the long-run steady state MFP level when domestic business R\&D spending is relatively high (Andrews and Westmore, 2014). The figure shows the difference in the effect of the "high frontier growth" scenario on GDP per capita at 2060 relative to the effect under the base specification of the model. For example, while the additional GDP per capita effect of using the re specified model is minimal in Slovakia, in Switzerland, the high frontier growth scenario results in GDP per capitaat 2060 that is $2.5 \%$ higher using the re specified model than when the same scenario is run in the base specification.

Source: OECD estimates. 
3.3 Labour and education policies have to adjust to changing demographics and rising skill requirements

\subsubsection{Retirement reforms and immigration friendly policies are two ways to address ageing}

49. Unfavourable demographics will lead to shrinking labour supply and slower growth in many countries, even if the retirement age is assumed to be adjusted for longevity in the central scenario. In this scenario, retirement reforms that raise labour force participation and employment include two phases. First, the implementation of recently legislated pension reforms will increase the average OECD retirement age from around 63 to 65 by 2030 (OECD; 2014). Secondly, rising longevity is assumed to be accompanied by further reforms to extend working lives so as to keep the share of active lives constant even as life expectancy increases. This further increases labour force participation rates in 2060 by a total average of 2.4 percentage points (Figure 14). Clearly, the gap between legislated and needed reforms is substantial and the possibility that the implementation of these further reforms may stumble on political obstacles should be pre-empted via adequate communication and sequencing.

\section{Figure 14. Longevity adjustment of the retirement age increases labour force participation}

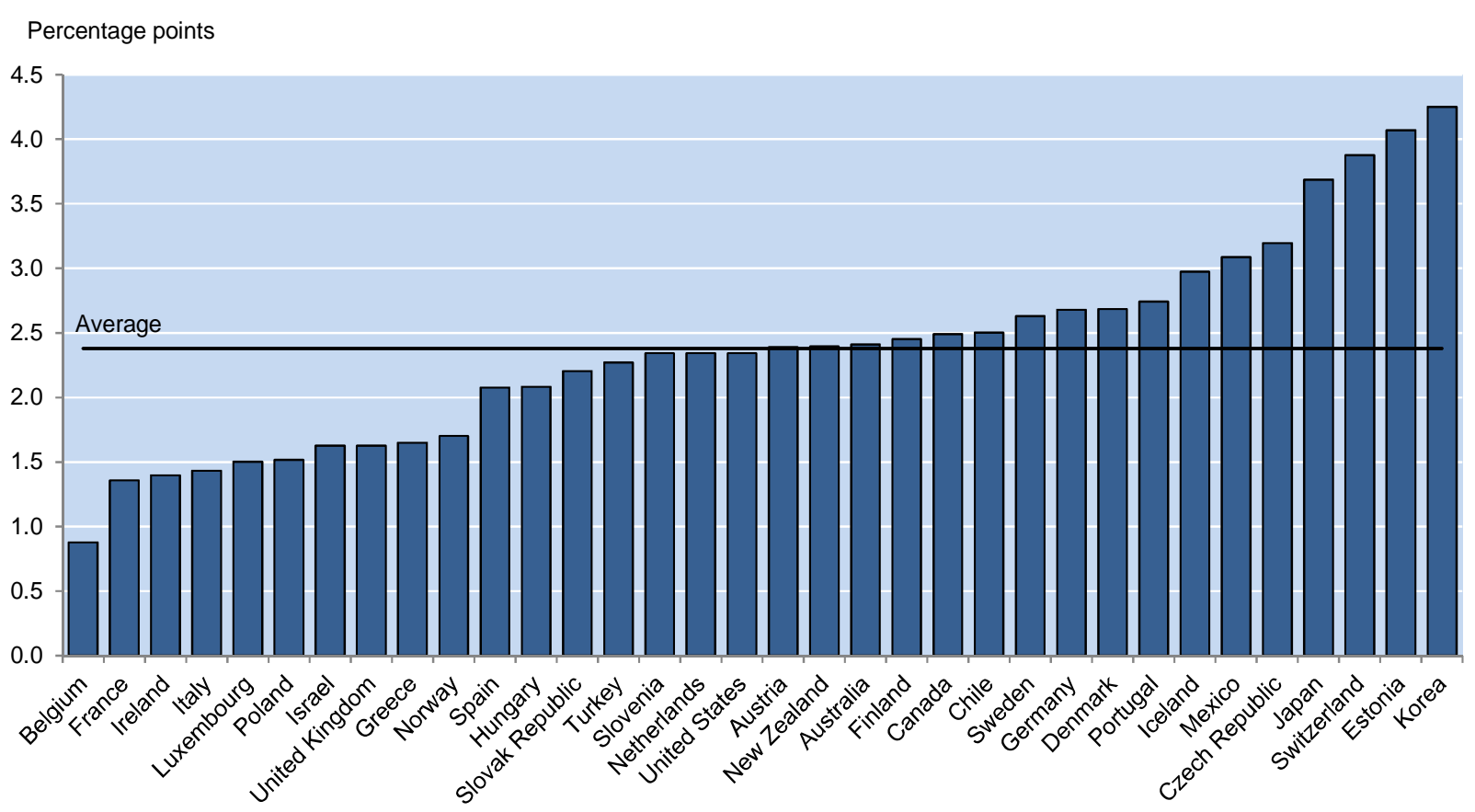

StatLink 규믄 http://dx.doi.org/10.1787/888933094659

Source: OECD Economic Outlook 95 long-term database, OECD calculations.

50. In parallel, policy makers in OECD countries cannot take for granted that large migration inflows will ameliorate an already difficult demographic situation, as wage convergence between OECD and nonOECD countries could lower incentives for work-related migration (Westmore, 2014). Hence, OECD countries may need to pursue more migration-friendly policies in order to encourage labour-related inward migration. While migration policies aiming to control population flows have often not been successful in achieving their stated objectives (Skeldon, 2008), there may be scope for well-designed government programs that seek to attract certain types of workers. For instance, Hatton and Williamson (2002) argue that changes in US immigration policy were important in influencing the volume and 
composition of migration flows throughout the 20th Century. There are a number of distinct types of immigration policies (e.g. skills based point systems, family reunification programs, refugee policy, illegal immigrant policy), which can be calibrated to target different groups of migrants. Settings in one country may also have spillover effects on other regions. For example, a change in policy to attract more low skilled workers may be more effective if it is introduced at a time when a number of other destination countries are implementing less accommodative measures for such migrants.

51. Benign structural policy settings can also attract inward migration and help make the most of immigration, for instance by providing migrants good access to jobs and opportunities for starting businesses. Indeed, less strict business regulations appear to be positively associated with immigration (Westmore, 2014). Well-functioning labour markets may be especially important for immigrants, as they more often tend to be formally overqualified for their jobs than the native population (OECD, 2013g).

\subsection{A changing structure of labour demand combined with an ageing labour force will require emphasis on flexibility and matching issues}

52. Economic growth, technological change and changing patterns of specialisation will continue to generate shifts in the structure of labour demand. It is difficult to predict whether the pace of structural change will slow or increase over the coming 50 years. Figure 15 (panel A) suggests that the pace of structural change - measured in terms of the sectoral composition - may decline in the central scenario, especially in emerging economies that will be exhausting the shift out of primary production. These estimates only tell part of the story however, as shocks not incorporated in the central scenario will inevitably affect future developments, not least changes in demand patterns. Furthermore, within-sector structural change will continue as KBC-based growth entails substantial firm turnover. A flexible labour force and labour markets that facilitates mobility and job matching are likely to adapt more quickly to new skill requirements and changes in industrial and occupational structures. 


\section{Figure 15. Structural challenges to labour markets}

\section{A. Index of structural change}

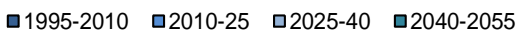

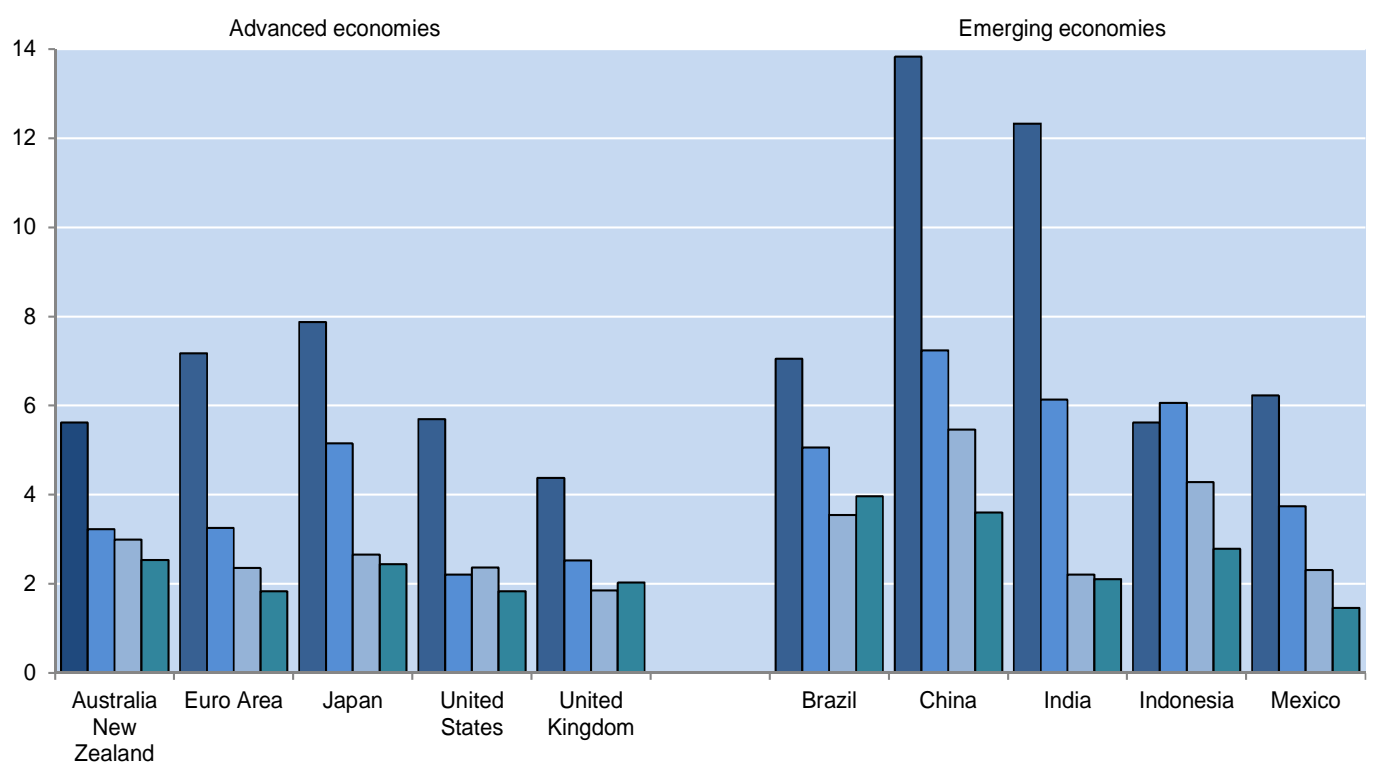

B. Average age of population aged 20 and more, $1950-2060$

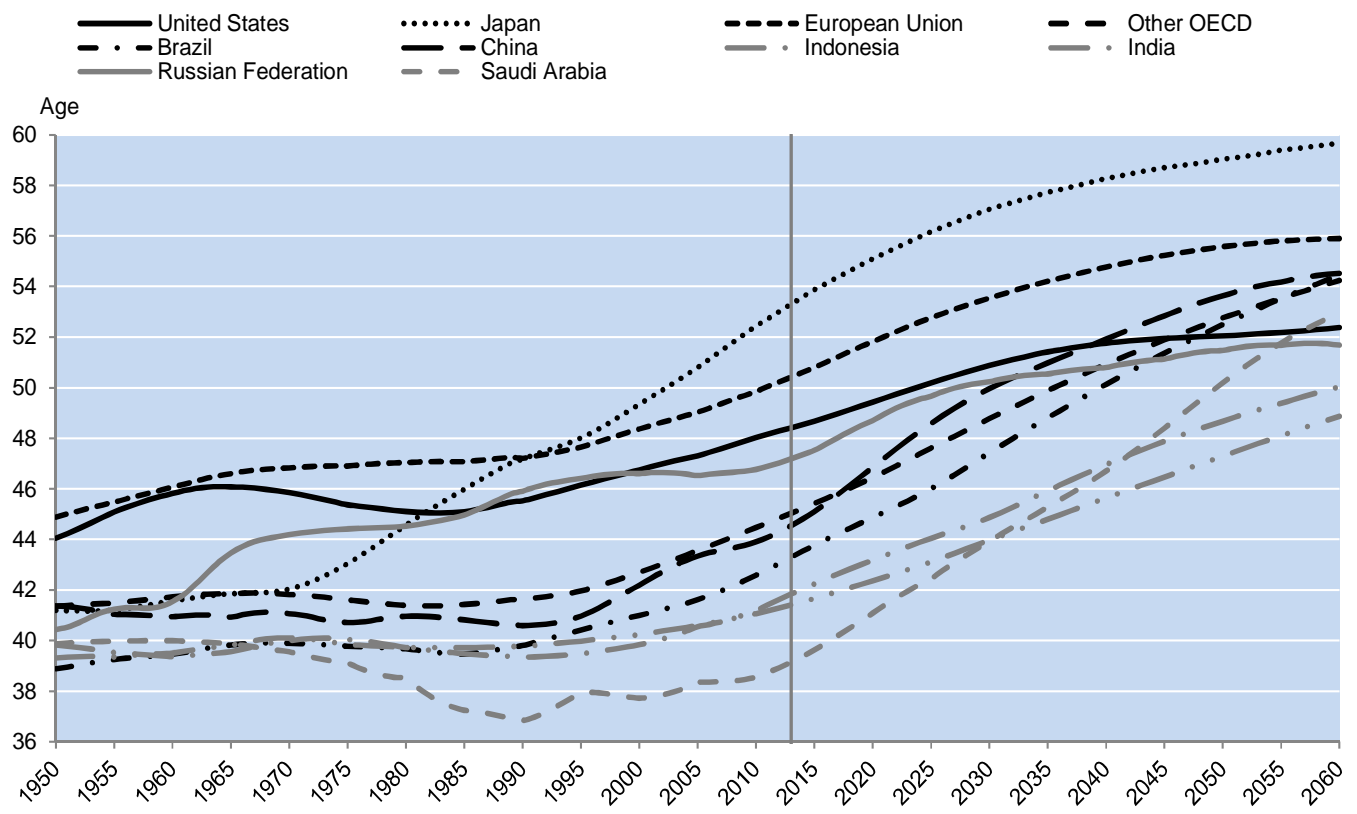

StatLink ज्ञाISL http://dx.doi.org/10.1787/888933094678

Note: The structural change index (SCl) is constructed as the annual absolute change in each industry's share of total value added, summed across industries and divided by 2 in order to produce an index bounded between 0 and 100 .

Hence

$$
S C I=\frac{1}{2} \sum\left|x_{i t}-x_{i t-1}\right|
$$

Source: OECD Economic Outlook 95 long-term database. 
53. However, over the coming 60 years labour forces will age substantially, reflecting both the composition of the population and likely increases in retirement ages (Figure 15, panel B). As the mean age of the workforce increases, labour supply is likely to become less dynamic. This may lead to lower risktaking, flexibility and geographic mobility with important repercussions for policy:

- A rising median age in the workforce will likely force a shift in the composition of active labour market policies. While younger workers tend to be unemployed frequently and for short spells, warranting a focus on search activities, older workers risk longer spells of unemployment and higher risks of exit out of the labour force. A shift in the pool of unemployed towards middleaged and older individuals with lower mobility, higher wage expectations and a larger occupation-specific human capital may require a stronger focus on maintaining and updating general skills as well as lowering reservation wages.

- Longer working careers, ageing and rising skill-requirements will also increase the need for onjob training and out-of-job retraining. An ageing workforce and longer working-lives will mean a longer period where depreciation of skills and technological change risk making human capital obsolete. This effect is accentuated by the fact that key skills depreciate with age, especially when adjusting for education and demographic factors (Figure 16).

- $\quad$ Other measures to improve labour-market matching can complement activation policies in building and maintaining human capital. For instance, lower employment protection - at least on permanent contracts - may make employers more willing to hire workers whose skills and formal qualifications are not up to expected standards initially, in the expectation that they may develop these skills "on-the-job". This is important, because skills are also affected by labour market experience, where appropriately challenging tasks can help to maintain and develop skills, whereas underutilisation of individuals' skills may lead to faster depreciation of human capital.

\section{Figure 16. Literacy and numeracy skills and age}

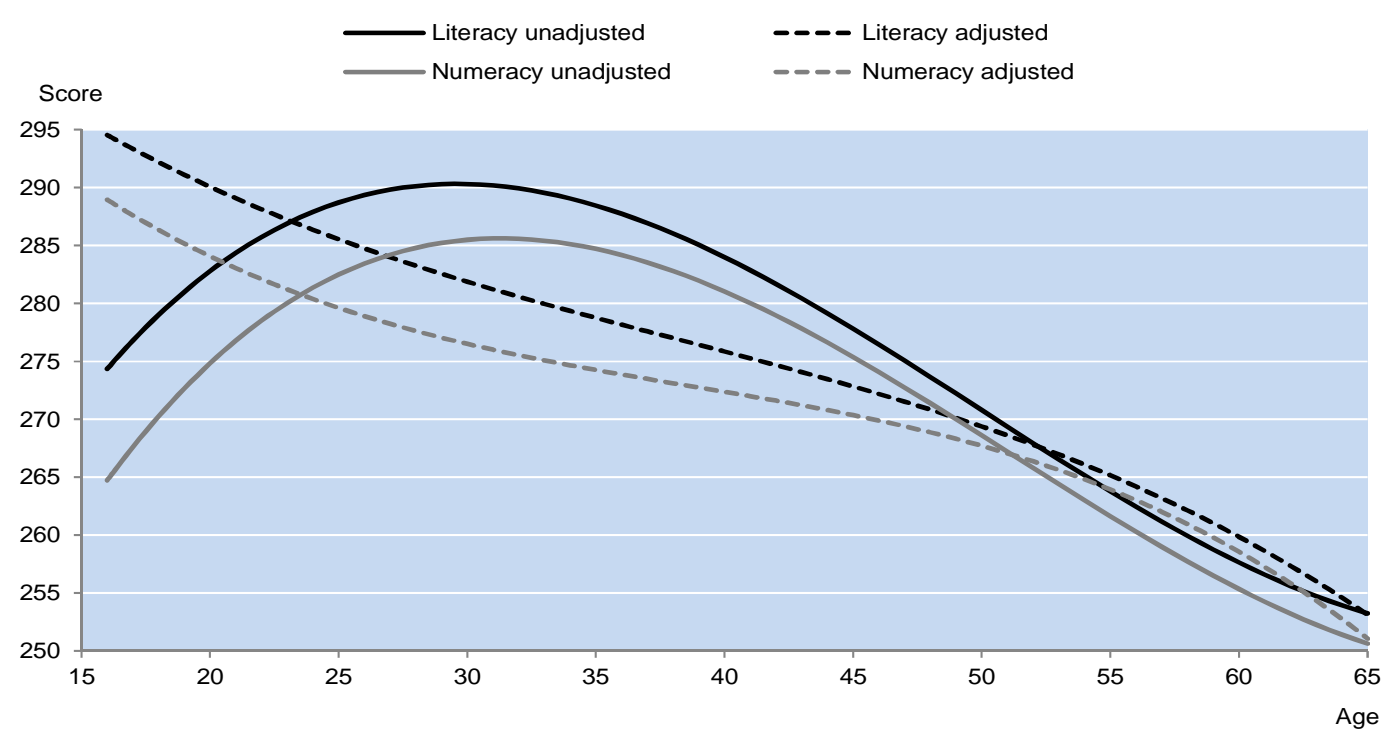

StatLink 羿ISL http://dx.doi.org/10.1787/888933094697

Note: Adjusted values refer to scores adjusted for educational and demographic background factors.

Source: Survey of Adult Skills (PIAAC; 2013). 


\subsubsection{Rising demand for skills will have important repercussions for education policies}

54. Knowledge-based growth will require an increasingly skilled labour force. Skill requirements will continue to increase and change as a consequence of skill-biased technical change, changing specialisation patterns and an evolving demand composition. ${ }^{19}$ Educational policies will therefore be crucial in shaping growth, but achieving large increases in educational attainment and skills will entail substantial challenges:

- $\quad$ Social excess returns to education are high, but relate mostly to earlier stages of education and especially for disadvantaged individuals (Heckman et al., 2005). Increasing the quality of lower level schooling across broad segments of the population will thus be important both for securing improved productivity, but also for achieving rising participation in higher education. ${ }^{20}$ High quality primary and secondary education will therefore be a prerequisite for raising skill levels and expanding tertiary education and should be prioritised in public funding.

- While longer working lives will increase incentives to invest in education, it will also raise risks that acquired education and skills become obsolete, requiring an increased emphasis on life-long learning. The case for government support for life-long learning may in fact be stronger here than for tertiary education for the young, as lower cross-country mobility among older workers means that the social benefits in terms of higher productivity and longer careers to a larger extent will benefit the domestic economy.

\section{Fiscal constraints and international mobility of skilled labour will make co-payments for higher education more attractive}

55. Private benefits of participation in higher education will likely remain high due to increasing relative demand for skilled labour. Meeting the expected rise in demand for tertiary education will entail substantial strains on public budgets if alternative funding sources are not found or new cheaper studying arrangements do not make significant inroads. As highlighted in the previous section, a government funded expansion to meet the higher demand for tertiary graduations embedded in the central scenario may raise public spending by around 1\% of GDP in the average OECD country if spending per student remains constant. ${ }^{21}$ Funding arrangements for tertiary education vary extensively across the OECD, but pressures for larger co-payments by students may rise across the board.

56. A shift towards higher student co-payments can have several benefits:

- In its absence, fiscal constraints could hold back funding for tertiary education, leading to stagnant supply of graduate studies openings or falling funding per student, which could hamper growth and increase earning dispersion relative to the central scenario.

- There may also be efficiency reasons for increasing student co-payments. As shown in Braconier, 2014, the supply of graduates seems substantially more sensitive to increasing levels of copayments than to increasing funds from government or corporate sources, without having a

19 At the same time, to the extent that the pace of technological progress will tend to slow as convergence takes place and structural change slows down, it may be the case that skill requirements will increase less rapidly than in recent decades.

The analysis in Braconier (2014) shows that improved educational performance in secondary schooling measured as PISA scores - raises demand for education and enhances supply of tertiary education. A higher quality of entrants into tertiary education will make students' progress more easily, less likely to drop out, and will also affect peers ability to progress positively (Winston, 1999).

Braconier (2014) provides two alternative scenarios for graduation rates up to 2060 in terms of total direct costs and fiscal costs of expanding tertiary education. The scenarios are maintaining current levels of graduation, and expanding graduations in line with demand with either public or private funding. 
negative impact on demand. ${ }^{22}$ Based on these estimates, total direct costs of tertiary education would rise by $0.2 \%$ of GDP in the average OECD country if increases in funding came from household co-payments, while the increase would amount to $1.0 \%$ of GDP if increases were covered by public funding. ${ }^{23}$

- Rising internationalisation of higher education - with the number of students from OECD countries enrolled abroad more than doubling between 2000 and 2011 (OECD, 2013d) - and increasing international mobility of skilled labour, further strengthens the rationale for students to cover a larger share of the costs of tertiary education.

57. Altogether, this suggests that funding reforms where students finance a larger share of direct costs could align incentives better and provide additional funding for an expansion of tertiary education.

58. At the same time, an increasing reliance on tuition funding will require further developing loan systems to ensure an equitable access to tertiary education. Designing loan systems that are fully compatible with international student and labour mobility will be a challenge, but could provide a compromise between equitable access and the necessary resilience of public finances to cross-border labour mobility. In comparison to tax financed systems such a system is less vulnerable to free riding in a world with international mobility, where income taxes are paid in the country where the graduates are working.

59. In this context, loan systems with repayments contingent on income can also provide some insurance against risk. Indeed, while average private returns to education remain high, within-education class and within-occupation wage dispersion has increased, suggesting that risks relating to investment in education may be increasing. For example, recent evidence shows that qualification- and job mismatches are substantial in several OECD countries (OECD, 2013g).

60. Funding reforms are important to improve educational attainment levels, but new methods of training and studying may change the production of higher education dramatically over the coming 50 years. Increasing spread of participation in courses via internet, such as "massive online open courses" suggests ways to increase availability and participation at a low cost. To what extent these new methods can supplant traditional education - reliant on face-to-face interaction with professors and peers remains an open question.

\section{International spillovers from educational policies may mainly come through migration patterns}

61. Trade integration and cross-border labour mobility may generate spillovers of national education policies on partner countries. For instance, recent OECD work explores the national and global effects of slower increases in human capital stocks in China, India and Indonesia, finding that real GDP by 2060 is lowered by 7\% for China, 12\% for India and 9\% for Indonesia (Johansson and Olaberría, 2014). ${ }^{24}$

62. The slower upgrading of educational attainment in these emerging economies may spill over globally through trade and migration patterns. Trade spillovers mainly take place through changing patterns of specialisation, with less upgrading of skills pushing up relative wages of skilled labour and slowing the process of specialisation in more human capital intensive production (such as electronics and services). As a consequence, OECD economies will retain more of their comparative advantage in these areas. Nevertheless, the effects on wages in trading partners seem minor (Johansson and Olaberría, 2014).

22 This likely reflects that universities that rely more on co-payments become more focused on 'delivery' of degrees, but may also encourage students to finalize studies quickly and discourage entry of students with low probabilities of completing university. neither includes living expenses nor foregone earnings of students.

The central scenario projects that educational attainment levels in emerging economies will grow rapidly, for example with mean years of schooling tripling from 3 to 9 years in India between 1990 and 2060. 
63. Higher relative wages for skilled labour in China, India and Indonesia will also affect migration patterns towards the OECD. The analysis in Westmore, 2014 suggests that higher relative wages for skilled workers in emerging economies coming from less ambitious education policies will slow migration flows towards the OECD, whereas inflows of less-skilled migrants will increase. By 2060 the US stock of skilled migrants would then be lowered by around $0.4 \%$ of the labour force, while the stock of less-skilled migrants would be larger by roughly the same amount. For the Netherlands, the corresponding numbers would be $1.8 \%$ and $2.8 \%$ respectively.

\section{Policies to deal with rising inequality and pressures on social institutions}

\section{Box 8. Main policy conclusions on dealing with inequality and pressures on social institutions}

- Further improvements in educational attainment levels can support equity and growth.

- $\quad$ Tighter restrictions on product and labour markets and higher tax wedges would lower gross earning inequality. However, such reforms would hurt growth substantially.

- As more stringent product market regulation and higher tax wedges tend to affect employment negatively, the net impact of such reforms on household income inequality is uncertain. Trade-offs between growth and inequality in household incomes are therefore less severe than between growth and inequality in gross earnings.

- Tax and benefit systems cushion the impact of market income inequality on household disposable income through redistribution. Further global integration will likely increase costs of redistribution, sharpening the growth-equity trade-off provided by tax and benefit systems. Globalisation may also put labour market and social institutions under pressure.

64. The growing importance of the knowledge-based economy will reward skills. Skill-biased technological change (SBTC) has been a key driver behind rising earning and income inequality in recent decades (Braconier, H. and J. Ruiz Valenzuela , 2014), whereby technological progress has substituted for routine and medium-level tasks, thereby displacing workers, while increasing the value of other "new economy" tasks (Autor et al., 1998). In the central scenario technological progress is assumed to continue to be skill-biased, following the same trend seen in recent decades.

65. While skill-biased technological change has been - and is likely to continue to be - the main driver of rising earning inequality, there is little scope for stopping SBTC. As the analysis in Annex 1 shows, SBTC is highly correlated with multifactor productivity growth, meaning that trying to hinder SBTC will slow productivity growth. Furthermore, the strong cross-country component in SBTC suggests that even if domestic productivity growth was stopped, global trends in SBTC would affect the domestic economy - through trade - in a skill-biased direction.

\subsection{Policy instruments that can lower earning inequality sometimes harm growth}

66. OECD analysis has identified complementarities and trade-offs in broad classes of policy settings vis à vis the twin objectives of enhancing growth and lowering income inequality (Fournier and Koske, 2012; OECD, 2013d; OECD, 2013f, Causa et al., 2014). In the central scenario, increasing educational attainment between 2010 and 2060 is expected to reduce earning inequality, measured as the D9/D1-ratio by roughly $10 \%$ in the average OECD country compared to what would have been the case if no increase would take place. ${ }^{25}$ As was discussed in section 2, further increases in educational attainment levels could help contain increases in earning inequality. In order to fully counter projected increases in earning

25 On the positive relationship between education and equity, de Gregorio and Lee (2002), Heckman (2005) and Koske et al. (2012) focus on different aspects. See also Causa et al. (2009) on the effects of education on social mobility. 
inequality, a very ambitious scaling up of education policies would be needed however. In turn, reducing inequality by other means could have positive repercussions on educational attainment as high inequality might reduce investment in education for poor households who are credit constrained.

67. Changes in structural policies and settings - such as regulations and structures in product and labour markets - over recent decades have contributed to rising earning inequality (OECD, 2011a; Braconier, H. and J. Ruiz Valenzuela, 2014). Reversing these developments could lower earning inequality. To illustrate how earnings-equalising structural reforms may impact earnings dispersion, a scenario is constructed in which product market regulations, employment protection, union coverage and tax wedges are assumed to converge to the highest levels prevailing in the OECD area around $2010 .^{26}$ The thought experiment, based on analysis in Braconier, H. and J. Ruiz Valenzuela, 2014, suggests that the baseline increase in earning inequality up until 2060 would be reduced from $30 \%$ to $16 \%$ for the average OECD country (Figure 17). Effects would be larger for English-speaking countries, where there is more room for policy settings to adjust.

\section{Figure 17. Decrease in earnings inequality if employment protection, union coverage, tax wedges and product market regulation converge to the highest levels in the sample (2060)}

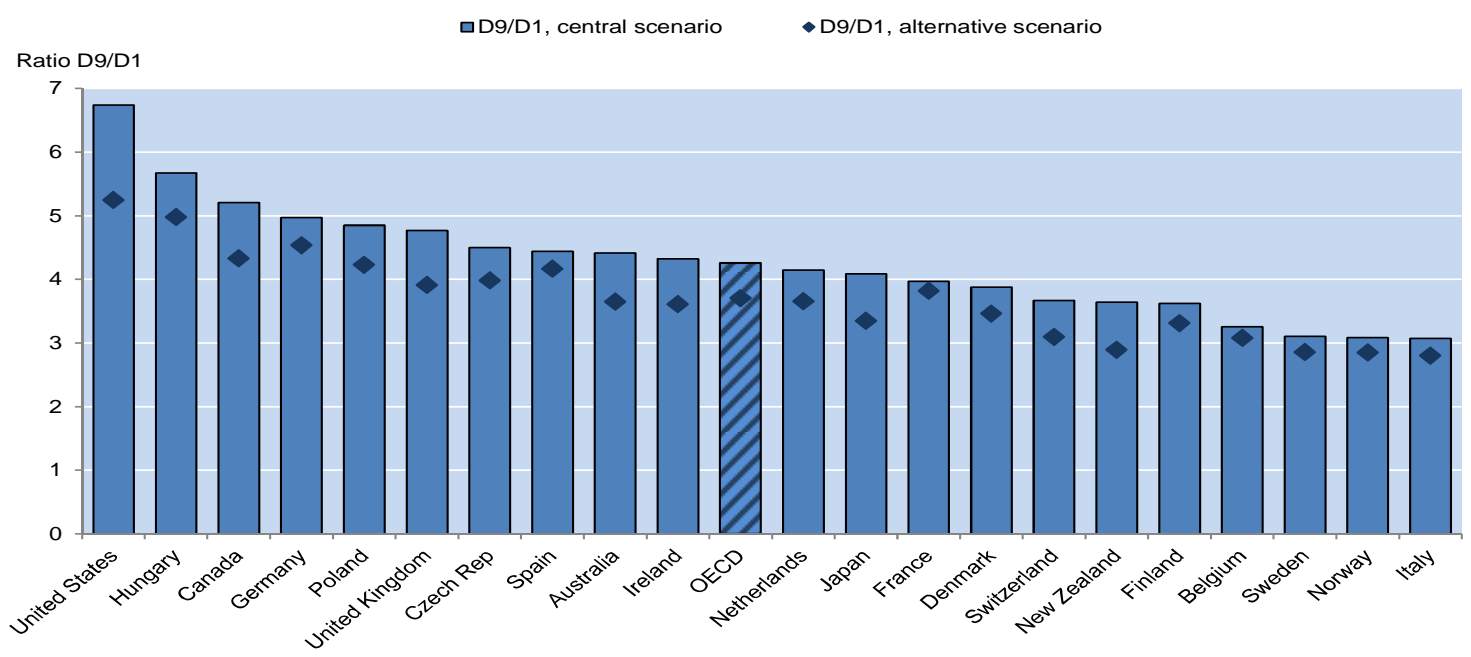

StatLink 켚ㄴ http://dx.doi.org/10.1787/888933094716

Note: OECD: average of the 21 included countries. Highest levels are identified for the last available year in the sample. These correspond to: France (employment protection), Austria (union coverage), Belgium (tax wedges) and Poland (product market regulation).

Source: OECD estimates.

68. However, as indicated in Table 1, such earning-equalising reforms would - perhaps severely harm growth, reflecting an acute trade-off. ${ }^{27}$ This negative impact is due to two types of mechanisms. First, especially in knowledge-based economies, extensive product market regulation tends to slow structural transformation, hampering the ability of the economy to fully benefit from new technologies and organizational improvements. Second, structural settings that tend to affect wages positively in the lower part of the spectrum may also lower employment, thereby affecting GDP negatively.

These anchors are provided, respectively, by Poland 2011 (product market regulation), Austria 2007 (union coverage), France 2008 (employment protection), and Belgium 2008 (tax wedge).

To give a numerical example the assumed tightening in product market regulation would - based on the estimates presented in Johansson et al.(2012) - lower GDP by around $20 \%$ on average for the countries in Figure 21. 
4.2 Trade-offs between the distribution of household disposable income and growth are often less severe but may grow as international integration proceeds

69. Policies to address rising gross earning inequality are just one step to mitigate rising income inequality, however. Conceptually, the effect of any policy on after tax labour incomes in the lower part of the distribution can be decomposed into three effects: the gross wage effect, the employment effect and the net tax and benefit effect, where the D9/D1 earning-differential only incorporates the wage effect. For example, higher tax wedges seem to lower earning dispersion (Braconier, H. and J. Ruiz Valenzuela, 2014), but at the same time lower employment (Arnold et al., 2011). In addition, they also affect after tax incomes, with an inconclusive net effect on the inequality of disposable income (Causa et al., 2014). The influence of policies on labour market patterns (such as participation rates and the extent of part-time work) and tax and benefit systems are therefore important drivers of the wedge between gross earnings inequality and inequality of household disposable incomes. Sometimes these wedges are large enough to lead to diverging developments of gross earnings and household disposable incomes (Table 1, columns 3 and 4).

\section{Table 1. Impact of structural reforms on growth, earning dispersion and equality in household} incomes

\begin{tabular}{|c|c|c|c|c|}
\hline & Effect on GDP & Effect on employment & $\begin{array}{l}\text { Effect on earning } \\
\text { equality (D9/D1) }\end{array}$ & $\begin{array}{c}\text { Effect on equality } \\
\text { in disposable } \\
\text { income }\end{array}$ \\
\hline $\begin{array}{l}\text { Increasing } \\
\text { overall } \\
\text { employment } \\
\text { protection }\end{array}$ & $\begin{array}{c}\text { 0/- } \\
\text { (Bouis et al., 2011; Causa et } \\
\text { al., 2014) }\end{array}$ & $\begin{array}{c}0 \\
\text { (Bassanini and Duval, } \\
2006 \text {;OECD, 2011b) }\end{array}$ & $\begin{array}{l}\stackrel{+}{\text { (OECD,2011b; }} \\
\text { Braconier and Ruiz } \\
\text { Valenzuela, 2014) }\end{array}$ & $\begin{array}{c}? \\
\text { (Causa et al., } \\
\text { 2014) }\end{array}$ \\
\hline $\begin{array}{l}\text { Higher union } \\
\text { coverage }\end{array}$ & $?$ & (OECD, 2011b) & $\begin{array}{c}+ \\
(\text { OECD, 2011b; } \\
\text { Fournier and Koske, } \\
\text { 2012) }\end{array}$ & $?$ \\
\hline $\begin{array}{l}\text { More stringent } \\
\text { product } \\
\text { market } \\
\text { regulation }\end{array}$ & $\begin{array}{c}- \\
\text { (Bouis et al., 2011; } \\
\text { Johansson and Olaberría, } \\
\text { 2014) }\end{array}$ & $\begin{array}{c}\text { - * } \\
\text { (Bassanini and Duval, } \\
\text { 2006; OECD, 2011b) }\end{array}$ & $\begin{array}{c}+ \\
\text { (OECD, 2011b, } \\
\text { Braconier and Ruiz } \\
\text { Valenzuela, 2014) }\end{array}$ & $\begin{array}{c}\text { - } \\
\text { (Causa et al., } \\
\text { 2014) }\end{array}$ \\
\hline $\begin{array}{l}\text { Higher tax } \\
\text { wedges }\end{array}$ & $\begin{array}{c}\text { - } \\
\text { (Arnold et al., 2011; Causa et } \\
\text { al., 2014) }\end{array}$ & $\begin{array}{l}\text { - } \\
\text { (Bassanini and Duval, } \\
\text { 2006; OECD, 2011b) }\end{array}$ & $\begin{array}{c}+ \\
(\mathrm{OECD}, 2011 \mathrm{~b})\end{array}$ & $\begin{array}{c}0 \\
\text { (Causa et al., } \\
2014)\end{array}$ \\
\hline $\begin{array}{l}\text { Higher } \\
\text { unemployment } \\
\text { benefits }\end{array}$ & $\begin{array}{c}? \\
\text { (Causa et al., 2014) }\end{array}$ & $\begin{array}{c}\text { - } \\
\text { (Bassanini and Duval, } \\
\text { 2006; OECD, 2011b) }\end{array}$ & (OECD, 2011b) & $\begin{array}{l}\mathbf{0 / +}{ }^{* \star} \\
\text { (Causa et al., } \\
\text { 2014) }\end{array}$ \\
\hline
\end{tabular}

Notes: * Bassanini and Duval (2006) find a negative and significant effect for female but not for male employment rates. ${ }^{\star *}$ The positive effect relates to benefits for long-term unemployed. 
70. Differential impacts of structural reforms on earnings inequality and employment sometimes raise difficult policy trade-offs. The severity of these trade-offs varies across policies. For example, product market reforms tend to increase employment but also raise earning inequality (Table 1). In contrast many pro-employment policies - like lowering the gap in employment protection between those on permanent and temporary contracts - will also tend to lower inequality and thus do not exhibit such a trade-off (OECD, 2012a). The severity of trade-offs can be mitigated by combining structural reforms with conditionality. Strict conditionality may, for example, mitigate the negative employment effects of large tax wedges or high unemployment benefits.

71. In general, tax and transfer systems cushion the impact of changes in market earnings to household disposable income, but as transfer systems in the OECD area have become less redistributive, their mitigating impact has decreased over the past decades (OECD, 2011b; Joumard et al., 2012). While the redistributive impact tends to be larger in countries with higher pre-tax and pre-transfer income inequality, there is substantial cross-country variation in efficacy, mainly due to the redistributive effects of transfers (Figure 18). This suggests scope for better-targeted tax and benefit systems to mitigate the impact of rising market income inequality on household income dispersion in many countries. Welldesigned social benefit systems also provide additional benefits through providing ex-ante risk-insurance (and thus ex-post equity), while lowering moral hazard and incentive problems (and thus more efficiency) through conditionality (Andersen, 2013).

Figure 18. Taxes and transfers reduce income dispersion, and more so in "unequal" countries

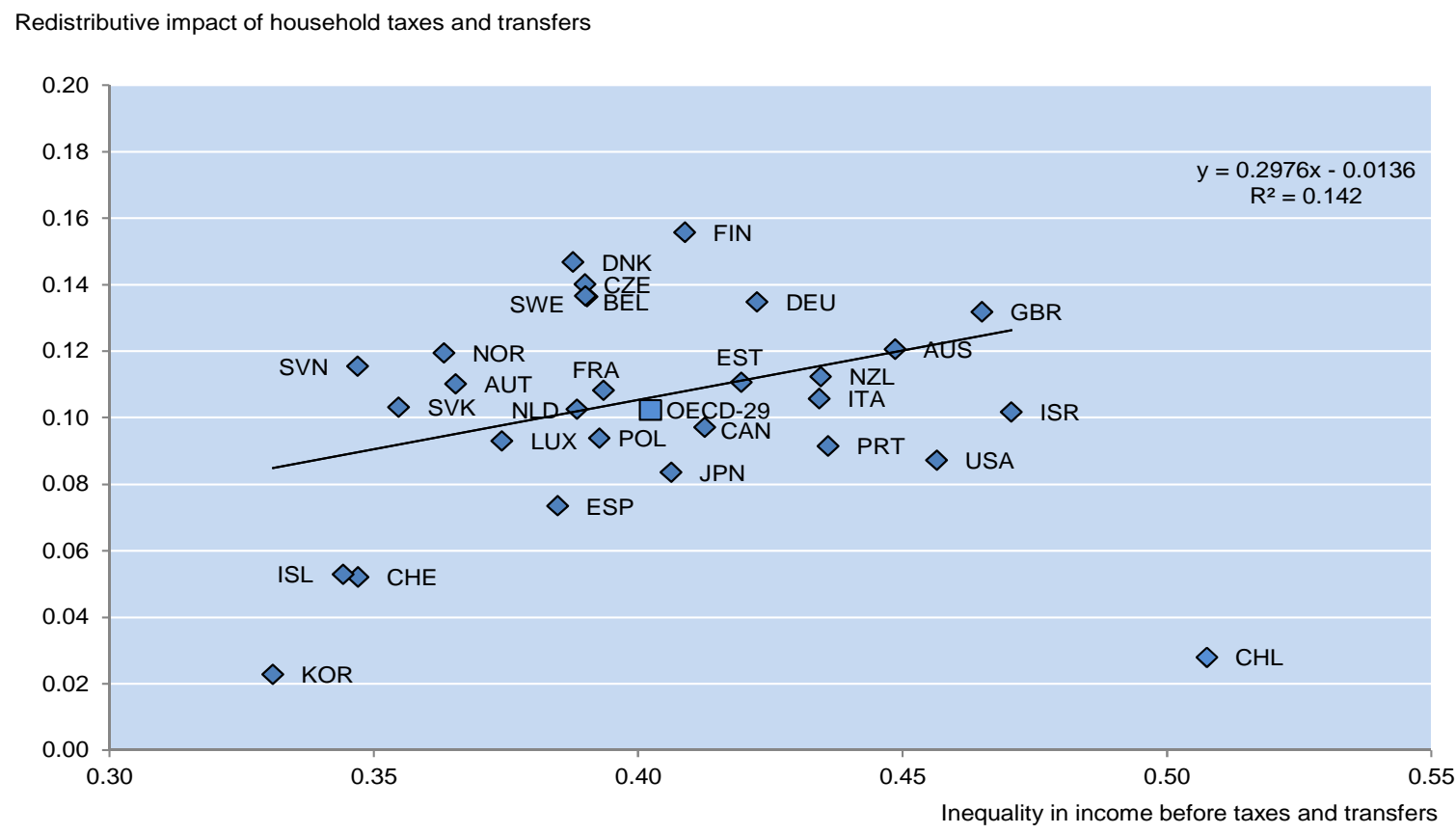

Note: Inequality in income before taxes and transfers is measured by the concentration coefficient. The redistributive impact of taxes and transfers is defined as the difference in the concentration coefficients for income before cash transfers and taxes (i.e. household market income) and after cash transfers and taxes (i.e. household disposable income). Two approaches can be used to measure the concentration of market income, i.e. by ranking households by their market income or by their disposable income. In this illustration, and throughout the paper, households have been ranked by disposable income due to data limitations (see Box 4.1 for more discussion). The trend line shown above has been calculated excluding Chile.

Source: OECD Household Income Distribution and Poverty Database, December 2012.

72. Increasing global integration and rising competition for mobile skilled workers may reduce the economic viability of some redistribution instruments, as these often impose costs on firms and taxpayers. 
This could lead to an institutional "race to the bottom" (Myles and Quadagno, 2002). The concomitant increases of the demand for redistribution (as earning differentials increase) and of the costs of redistribution points to a sharpening growth-equity trade-off for national policy makers. This challenge can be addressed in three ways: greater reliance on increasing equality of opportunity, such as educational reforms already discussed; a shift of taxes from mobile to less mobile tax bases; increased international coordination of tax policies. The latter two options will be discussed in section 6 .

73. A "race to the bottom" is by no means a certain outcome of further global integration and SBTC. First, many labour market and social institutions provide income insurance against productivity, unemployment and health risks (Andersen, 2008). To the extent that rising globalisation and SBTC would imply larger such risks, the demand (and willingness to pay) for insurance would likely rise as they proceed. Second, there is only patchy evidence that rising global integration so far has affected the extent of social and labour market reforms. While corporate taxes, product market regulation and union density have fallen significantly since 1980, (regular) employment protection has remained fairly stable (Figure 19). Third, the projected strong growth of emerging economies is likely to result in labour market institutions in these regions becoming more developed and social spending rising in relation to GDP. 
Figure 19. Changes in labour market institutions and policies, 1980-2008

A. Union density rate

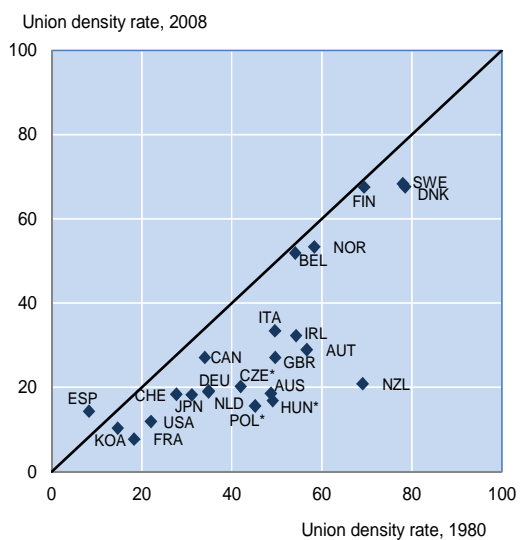

C. Product market regulation (PMR)

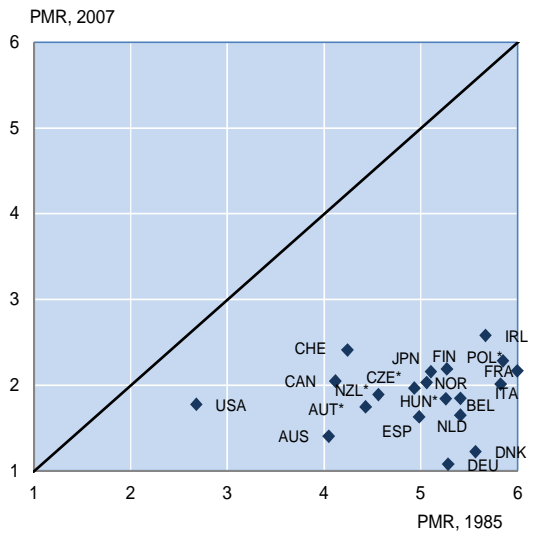

E. Tax wedges (single, average wage)

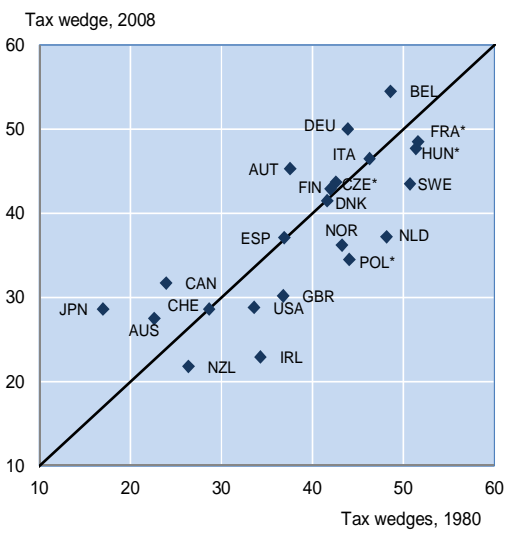

B. Union coverage rate

Union coverage rate, 2008

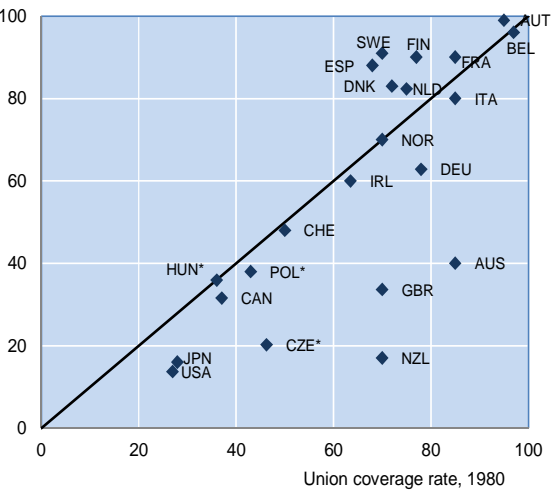

D. EPL for regular workers

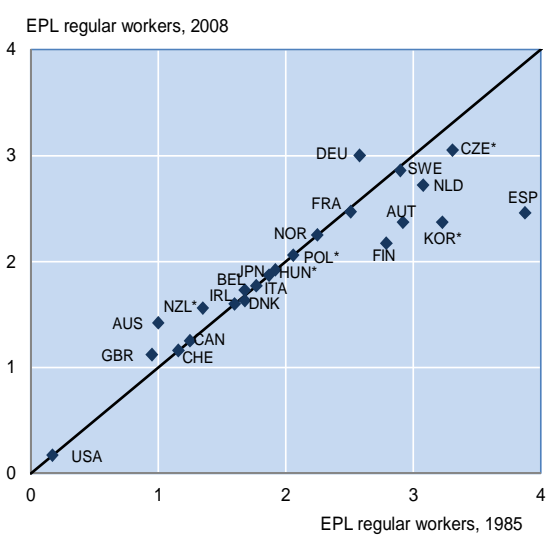

EPL regular workers, 1985

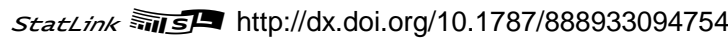

Note: The series begin in the 90 s.

Source: Union coverage (B) and union centralisation/coordination (C) from Visser (2009); all others are from OECD employment database, OECD Taxing Wages Database and OECD Benefits and Wages Database, OECD (2011), Divided We Stand: Why Inequality Keeps Rising. 


\section{Box 9. Policies to address climate change}

- Dealing with climate change requires a balanced set of policies to (i) mitigate climate change by reducing emissions that are the drivers of climate change, and (ii) adapt to the remaining impacts.

- A broad policy mix is needed to mitigate climate change, with appropriate pricing of carbon complemented by more targeted measures that may include reforming fossil-fuel subsidies, standards and regulations, increased investment in $R \& D$, regulatory reforms of energy and transport markets and information-based policies.

- A negative side-effect of rising trade integration could be that the location of emissionintensive production becomes more sensitive to energy-prices, promoting tax and subsidy competition and excessive emissions. In the absence of a binding multilateral agreement on emissions reduction, pressure for alternative mechanisms such as border carbon adjustments will increasingly be felt. The potential costs and practical difficulties of implementing such measures should provide a strong incentive to find a globally coordinated solution. In the meantime, regional cooperation such as through plurilateral linking of carbon markets can help to reduce effects of carbon emissions "leakage".

- At the same time, integrated economies may be better able to share the costs of climate damages through shifting trade patterns in response. Given that regional environmental impacts are hard to predict, international trade and investment integration provides some insurance against climate change risk, as long as impacts are not strongly positively correlated across regions.

- A switch towards more environmentally friendly sources of energy could lower climate change damages and improve global welfare, but may require some substantial initial upfront investment.

74. As discussed in section 2, the full costs of climate change will be felt beyond 2060, but costs will already be significant by 2060 in the central scenario. These costs should be seen in the context of rising risks for threshold effects that would trigger a major negative event, due to the inertia built into polluting production systems (e.g. energy plants and transport systems) and atmospheric greenhouse gas concentrations. There is therefore a need for swift policy action both for mitigation and for adaptation (OECD, 2009).

75. A broad policy mix is needed to mitigate climate change, with appropriate pricing of carbon complemented by more targeted measures that may include reform of fossil-fuel subsidies, standards and regulations (e.g. energy efficiency standards in buildings), increased investment in R\&D, energy market regulation reforms and information-based policies (e.g. energy efficiency labels). Such policies woud not only help to address environmental damages, but could also generate significant fiscal revenues. For example, recent analysis (OECD, 2013i) identifies 550 measures that support fossil-fuel production or use, amounting to USD 90 billion in 2011. Meanwhile, the IEA estimates that price-driven subsidies encouraging the consumption of fossil fuels in a selection of emerging and developing countries amounted to approximately USD 544 billion in 2012 (IEA, 2013). Estimates in OECD (2009) suggest that fiscal revenues from stabilising CO2 concentration around 450 parts per million (ppm) could amount to 6\% of GDP in 2050, although large uncertainties surround these estimates.

76. Comparable cross-country data gathered by the OECD shows a significant increase in the use and stringency of environmental policy instruments over the past two decades, helping to limit the economic risks of unabated environmental damage. In addition, increasing stringency does not seem to harm productivity, and the most technologically-advanced industries and firms have experienced higher productivity levels as a result of tightening environmental policies (Kozluk et al., 2014) 
77. The global consequences of climate change point to the need for a cooperative policy solution. Countries are working through the UN towards a global agreement in 2015, but challenges to co-operation are substantial, reflecting the fact that costs and benefits differ widely across countries. ${ }^{28}$ Convergence in per capita income over the coming 50 years may lower somewhat global differences in preference for emission abatement and climate change mitigation. This could facilitate coordination, but the heterogeneous economic impacts of climate change may hinder it.

78. Coordination problems may be exacerbated by further falls in trade costs, which will make the localisation of high-emission activities more sensitive to local costs and may dissuade countries from imposing higher carbon prices. In the absence of enhanced international co-operation on emissions reduction agreed at the multilateral level, pressure for alternative mechanisms such as border carbon adjustments will increasingly be felt notwithstanding the practical difficulties their implementation would raise (Cosbey, 2008). The potential costs of such measures should provide a strong incentive to find a globally coordinated solution. In the meantime, regional cooperation such as through plurilateral linking of carbon markets can help to reduce effects of carbon emissions "leakage".

79. Changing climatic conditions will affect relative production costs and therefore comparative advantages of countries. For example, a climate change-induced decline in agricultural production in South-East Asia could subtract around 1.7\% from GDP in the region at 2060 (Figure 20; Braconier and Dellink, 2014). Further global trade integration can lower the costs of adapting to climate change by allowing specialisation patterns to shift and global adaptation to take place at a lower cost, although international trade also contributes to emissions.

Figure 20. Contribution to GDP impact from climate change at 2060 (central projection)

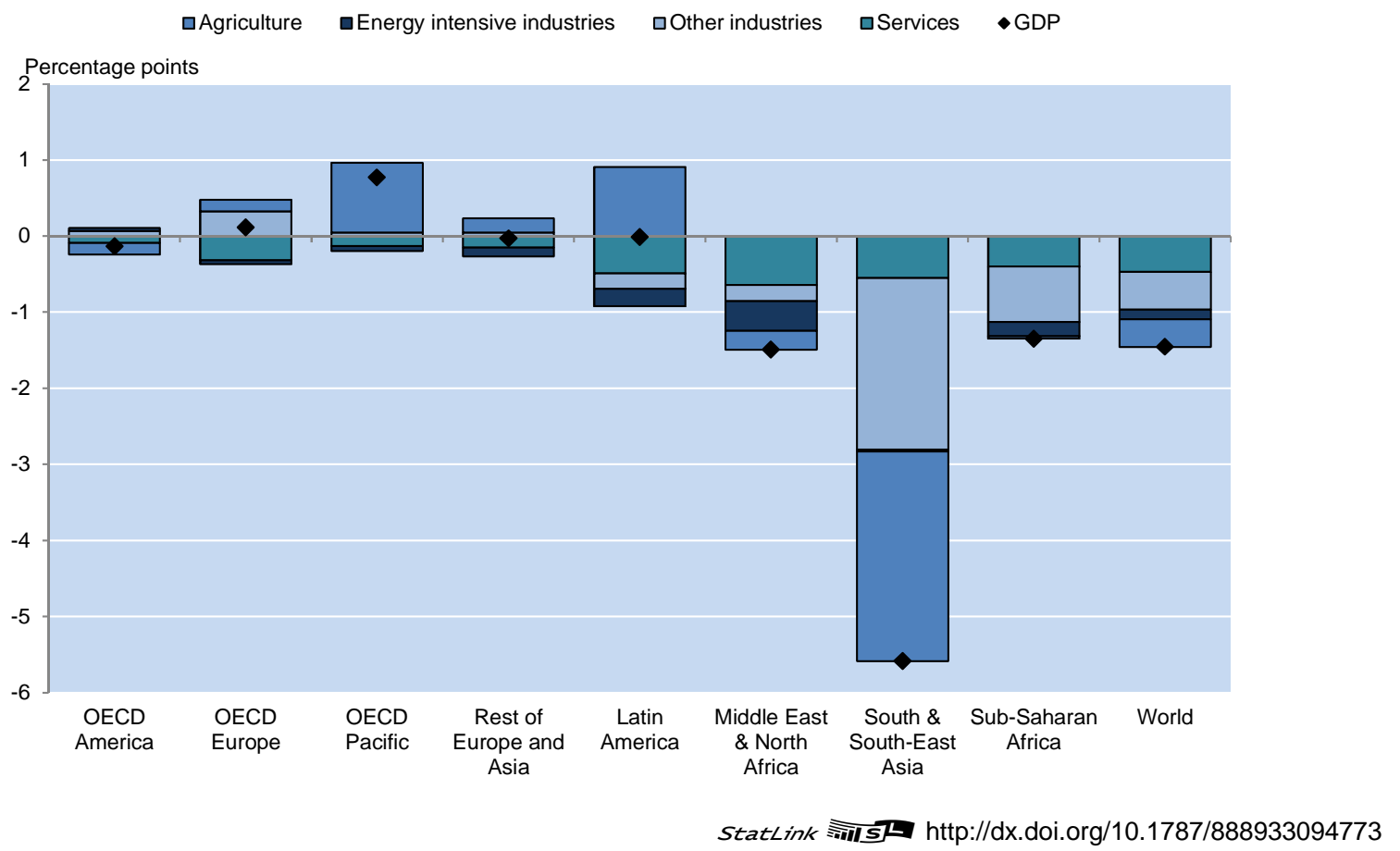

Note: The figure indicates percentage change in GDP at 2060 relative to the "no-damages" baseline.

Source: Braconier, H. and R. Dellink (2014) 
80. While estimates of global climate change damages are surrounded by uncertainties, the distribution of regional damages is even more uncertain. In addition, risks of more dramatic regional developments even within the coming 50 years are substantial, with associated costs in terms of disrupted food supply, lost output and environmental migration pressures. Given high levels of uncertainty around regional impacts, global risk-sharing mechanisms could be valuable. While trade integration provides one such mechanism further financial integration, especially in terms of long-term investment, could also improve risk sharing.

81. Climate change mitigation will require substantial investment in developing new technologies, improving the uptake of existing technologies, and developing greener energy systems. Similarly, climate change will mean that large investments in adaptation will be required, especially as a certain amount of damages from climate change are likely to be already "locked in". Enabling pension funds to invest more freely across borders could provide additional sources for long-term investment in mitigation and adaptation, without jeopardising macroeconomic balances.

\section{Policies to deal with the fiscal challenge}

\section{Box 10. Policies to deal with fiscal challenges}

- $\quad$ Fiscal pressures from fiscal gaps and health and pension spending are estimated to $10 \%$ of GDP in 2060 for the average OECD country, with additional fiscal risks associated with education cost and slowing migration. Dealing solely with these challenges through fiscal consolidation would substantially lower both growth and equity. Therefore, structural reforms to reduce reliance on public funding should be sought.

- In the light of large uncertainties relating to demographics and productivity, the resilience of public finances could be increased by moving to defined-contribution pension systems. This would however shift more risks towards participants.

- $\quad$ Further global integration will make some tax bases more mobile. Rising tax competition due to increased mobility will put pressure on environmental (production-based) taxes and corporate taxes, with negative impacts on the environment (and hence growth) and equity. One option will be to switch taxation towards less mobile tax bases including property, resource extraction and consumption based taxes.

- $\quad$ Stronger global tax coordination in areas where global negative externalities are large (e.g. carbon taxation) would be beneficial and could increase efficiency and raise revenues. These benefits will rise as global integration continues.

\subsection{Fiscal challenges could force countries to consolidate through increasingly bad instruments}

82. Section 2 described the fiscal challenges and risks that OECD countries will likely face over the coming 50 years. Recent OECD analysis has shown that many tools for fiscal consolidation imply trade-offs with growth, equity and current account imbalances, especially in the short run (Cournède et al, 2013). ${ }^{29}$ The extent to which countries should utilise consolidation instruments with negative side-effects depends on the scale of needed consolidation, national preferences in terms of income versus equity, and the relative efficacy of instruments. Table 2 gives the ranking of consolidation instruments based on their assessed impact on long-term growth and equity, disregarding country-specific factors and preferences. ${ }^{30}$

29 The long-term trade-offs are likely less severe however, as unsustainable debt positions will eventually harm growth and redistributive capacity.

30 See Cournède et al. (2013) for ranking based on country characteristics. 
Table 2. Assessment of long-term growth and equity effects of fiscal consolidation instruments

\begin{tabular}{lcc}
\hline \multicolumn{1}{c}{ Instrument } & Long-term ranking & Growth \\
\hline Subsidies & 1 & ++ \\
Pensions & 2 & ++ \\
Other property taxes & $3-6$ & + \\
Unemployment benefits & $3-6$ & + \\
Environmental taxes & $3-6$ & + \\
Recurrent taxes on immovable property & $7-9$ & + \\
Sales of goods and services & $7-9$ & + \\
Sickness and disability payments & $7-9$ & -- \\
Personal income taxes & $10-12$ & -- \\
Corporate income taxes & $10-12$ & - \\
Consumption taxes (other than environmental) & $10-12$ & - \\
Public investment & $13-14$ & - \\
Health services provided in kind & $13-14$ & - \\
Social security contributions & $15-16$ & - \\
Family & $15-16$ & - \\
Education & 17 & - \\
\hline
\end{tabular}

Note: The table shows effect of cut in spending or increase in tax on GDP growth and equity in the distribution of disposable income.

Source: Cournède et al., 2013; own calculations

83. This ranking provides a good starting point for strategies to address fiscal challenges, but some further issues apply when focusing on the 2060 horizon. First as shown in section 2 long-term consolidation needs are likely larger than those identified in Cournède et al. (2013). This may force countries to increasingly rely on "bad" instruments to address unsustainable fiscal positions - at least in the absence of structural reforms - with adverse effects on growth and equity. Second, fiscal costs of pensions (based on existing and legislated rules), expanding educational spending, and the risk of additional labour shortages from a drying up of immigration to OECD countries, adds to the estimated consolidation needs that Cournède et al. (2013) identify.

\subsection{Structural reforms can mitigate fiscal pressures and help managing risks}

84. In several cases, structural reforms can mitigate fiscal pressures without harming growth and equity, thus providing a way to avoid difficult trade-offs. As has already been discussed - and implicitly assumed in the baseline scenario - longevity adjustment of the retirement age can help resolving soaring pension deficits, while a stronger reliance on tuition fees can fund the expected growth in tertiary education. In both cases, positive side effects on growth (retirement reform) and equity (tuition reforms) could result, if policies are carefully implemented. Also in other areas, like financing of infrastructure or long-term care, a greater reliance on private funds could be considered.

85. Given uncertainty about future developments, structural reforms can also increase resilience of public finances to unexpected developments and exogenous shocks. State-dependent policies - including automatic longevity adjustment of retirement ages and balancing mechanisms in e.g. pension systems can be particularly useful here, although such policies in themselves do not resolve the trade-off between sustainability, adequacy and efficiency that social protection systems face, with generous systems often providing high adequacy, but low financial sustainability and efficiency (Fall et al., 2014). In the case of several of the main risks discussed in section 2 defined-contribution pension (both notional and fullyfunded) systems are more resilient to such shocks than defined-benefit systems. For example, when comparing pay-as-you-go pension systems with defined benefits (DB) and defined contributions (DC), Fall et al., (2014) shows that the effects of productivity, longevity and migration shocks will mainly affect the financial balance in the DB system but not in the DC system. However, this resilience comes at the cost of shifting more of income risks towards participants in a DC system (Lindbeck and Persson, 2003).

86. Demographic shocks can also impact the capital returns of funded pension systems, as a weaker development of the labour force leads to lower returns on domestic capital. Hence, policy settings that 
enable investment by pension funds in foreign markets can improve allocation of capital across countries and be beneficial both through raising returns and sharing productivity and migration risks. These benefits will however have to be weighed against the costs associated with higher exchange rate risk. Policy measures that facilitate the portability of workers' pension benefits may improve the allocation of labour to regions where shortages are most chronic, while countries that provide portable and attractive (actuarially neutral) pension benefits may be able to attract foreign workers.

\section{3 \\ Rising global integration may reorder the ranking of fiscal instruments over the coming fifty} years

87. The ranking of fiscal instruments may also change over the coming fifty years, as economic structures and policy objectives evolve and rising global integration potentially raises the efficiency losses of fiscal consolidation.

88. Rising global integration will further increase the cross-border mobility of capital and production, raising the deadweight costs of taxing these sources. In addition, the rising importance of knowledgeintensive (non-physical) assets and multinational enterprises in the global economy affects the ability of governments to collect taxes, as the possibilities to shift profits across borders are significant. Thus corporate income taxes, but also production-oriented environmental taxes, will likely become less efficient as fiscal instruments for the individual country.

89. At the same time, the risks that tax competition in these areas will drive down tax rates below optimal levels - with repercussions for income distribution and the environment respectively - points to potential gains from international tax coordination. ${ }^{31}$ As discussed in section 5 , the fiscal revenues from coordinated environmental action could be large. Such coordination has to be quite broadly encompassing however, as there would be some leakages from more limited participation. Similar arguments, although to a lesser extent, could also apply to personal income taxes given the income sensitivity of migration. ${ }^{32}$

90. Changes in the ranking of instruments may also vary across countries, reflecting how each is likely to move in terms of income levels and inequality. Countries that may experience above-average increases in incomes and inequality (such as the Czech Republic) may wish to prioritize fiscal instruments with lower impact on inequality (like raising personal income taxes), especially if their current position in terms of income and equity reflects social preferences. Conversely, countries that are likely to face belowaverage increases in incomes and inequality (such as New Zealand) may wish to put higher priority on using growth-enhancing fiscal instruments.

\section{Policies for greater macroeconomic stability over the coming fifty years}

\section{Box 11. Improving macroeconomic resilience and stability}

- With increasing economic integration, the effects of domestic shocks will be increasingly shared with trading partners, diminishing the domestic impact and hence the need for stabilisation policies. At the same time the efficacy of domestic fiscal policy for stabilisation will also diminish with increasing integration, pointing to an increasing scope for cooperative stabilisation policies, whenever possible.

- $\quad$ Concerted efforts in deficit and surplus countries to hinder a renewed build-up of current account imbalances is needed, including via both structural and fiscal measures.

31 See e.g. Sorensen (2004) for the benefits of global coordination on capital taxation and OECD (2009), page 87 on leakages related to restricting carbon emissions.

32 Given that knowledge based asset growth is highly reliant on the accumulation of mobile factors such as highly skilled labour, countries' ability to grow at the pace projected in the central scenario may depend on their ability to attract such factors. This could increase policy competition between countries, for example, through changes in the settings of income tax policy to attract skilled workers. Such a scenario has the potential to harm growth if it results in policy uncertainty or too much reallocation of mobile factors and, in such a case, may benefit from cross-country coordination of policies. 


\subsection{Rising trade integration will increase interdependence and could require stronger international coordination on fiscal and structural policies}

91. Trade and investment integration generates not only economic but also policy interdependence among partner countries. With world trade expected to increase from $25 \%$ to almost $45 \%$ of global GDP in the central scenario, the median OECD country will be 23\% more open in 2060 than in 2010. Moreover, international trade in intermediate inputs has grown even more rapidly than total trade, reflecting the increasing complexity of global supply chains, with the share of domestic value added in gross exports falling in most economies (Figure 21, panel A). Continued decline in transport and transaction costs, improved logistics and an increasing availability of ICT tools to manage production across locations and countries will likely mean that these trends will continue, although cost convergence across countries will dampen the impact (OECD, 2013d). Long and complex supply chains propagate supply shocks across borders effectively and quickly, as illustrated by the global repercussions of the 2011 Tohoku earthquake and tsunami that hit Japan (OECD, 2011). Combined with the rise in trade openness, these trends will likely result in the international spillovers from demand and supply shocks increasing steeply.

92. More intertwined economies will mean increased risk-sharing, where trading partners will share the burdens of country-specific shocks and policies. This will raise the exposure of countries to illexecuted and - if economic cycles are not synchronized - ill-timed policies in trading partners, while benefitting less from well-conducted domestic policies. Further coordination on stabilization and structural policies between close trade partners (like the EU) would therefore be useful (Di Giovanni and Levchenko, 2009). But, in the longer-run, it will be important for OECD countries to develop coordination with emerging economies. OECD countries' exposure to shocks emanating from emerging economies is already significant (OECD, 2013b). As trade integration proceeds and the importance of emerging economies in the world economy increases, the magnitude of such spillovers will rise rapidly (Figure 21, panel B). In 2060 euro area exports to Asia, Africa and Latin America will amount to 15\% of GDP and be as big as exports within the euro area. 
Figure 21. OECD countries will become increasingly exposed to shocks from emerging economies
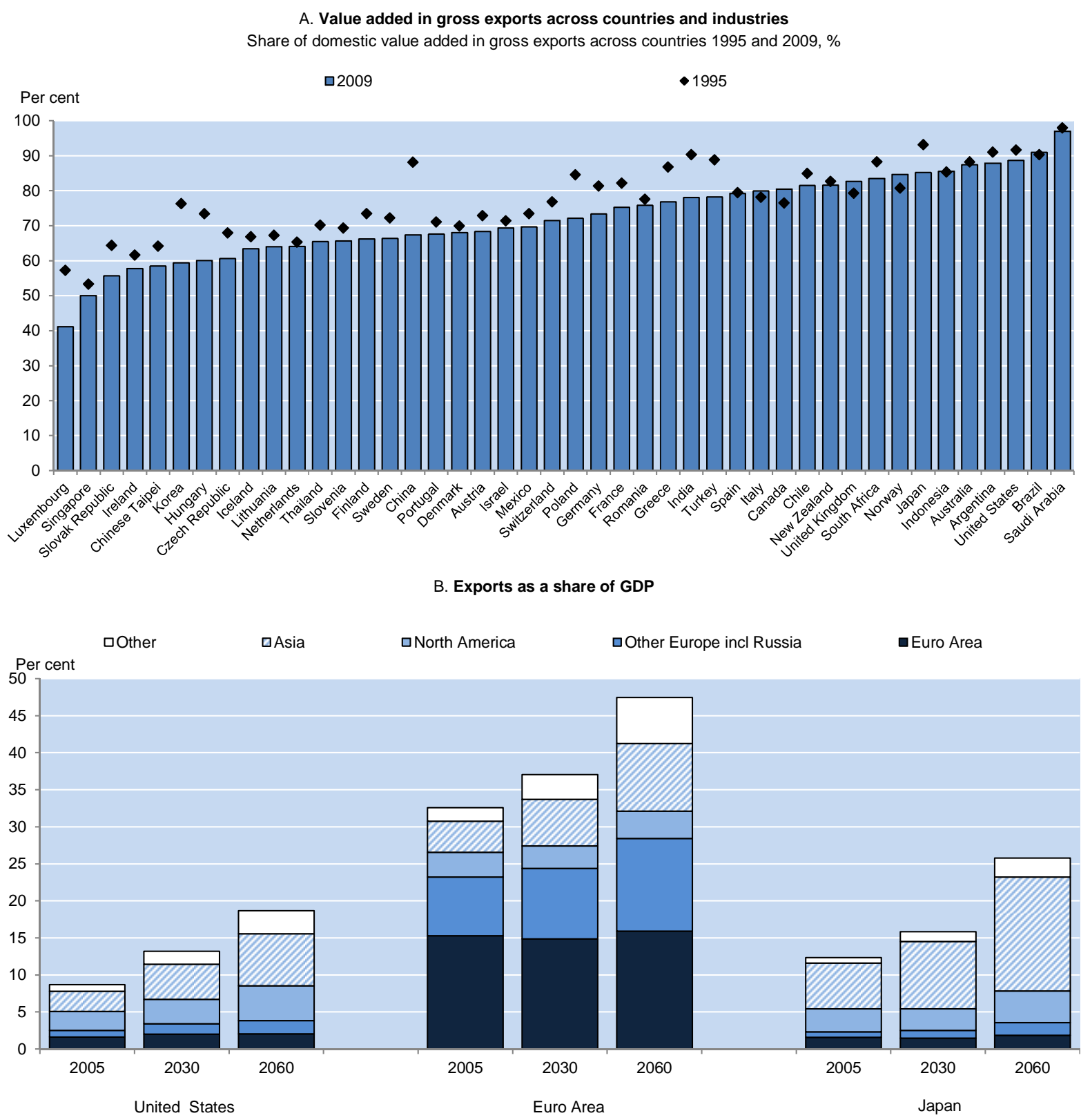

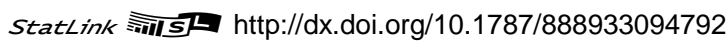

Source: Own calculations based on Johansson and Olaberría, 2014. 
93. Deeper integration should have a stabilizing impact on economies in general and make business cycles more synchronised. ${ }^{33}$ This stabilising effect may be more muted for OECD countries which will experience a rising exposure to emerging economies - where volatility tends to be higher. As cross-border trade increase, domestic fiscal multipliers are likely to diminish as leakages increase. Thus, while the impact of a given shock on the domestic economy decreases, the effectiveness of policies to address it both in terms of automatic stabilisers and discretionary measures - will also decrease. The need for domestic stabilisation policies may therefore fall, while the costs will increase. The benefits from international cooperation in monetary and fiscal action will rise, especially as business cycles become more synchronised.

\subsection{Polices to handle current account imbalances and mitigate their impact}

94. A targeted use of structural policy instruments could prevent a renewed build-up of current account imbalances in the medium term (OECD, 2013a): labour market reforms in euro area deficit countries and Japan, product market reforms in euro area surplus countries, less favourable tax treatment of interest expenses in the United States, and financial liberalisation and expanding social safety nets in China could raise growth, improve efficiency and dampen global imbalances (Figure 7; Ollivaud and Schwellnus, 2013).

95. In the longer term, demographic factors (including migration) and fiscal policies will tend to drive current account imbalances. Apart from addressing large imbalances, policies need to mitigate risks that global - and regional - imbalances lead to future macroeconomic crises. While the evolution of international financial linkages over the coming fifty years is very much an open question - reflecting uncertainty around the "rules of the game" that will emerge - the composition of those linkages matter to the probability that imbalances will lead to a crisis. A high reliance on short-term borrowing in foreign currency increases risks of current account and financial crises, whereas capital inflows in terms of FDI and equity seem to pose much less risks (Ahrend and Goujard, 2012). To the extent that the rising importance of knowledge-based assets in production and lower transport and trade costs continue to feed FDI, it can play an increasingly important role in mitigating current account risks. From this perspective, international policy coordination (e.g. on IPR or corporate taxation) could facilitate further FDI penetration and thus stability. For emerging countries further liberalization of capital controls has tended to make them less prone to current account crises (Frankel and Wei, 2004), although recent developments have challenged that view (Rey, 2013).

\section{Economic policies for a shifting world}

96. Even though the world economy will change substantially over the coming 50 years, many policy issues and priorities are likely to remain valid to 2060. Material living standards and life expectancy will probably keep improving substantially - especially in emerging economies - lifting billions out of poverty. Still, resource scarcity will persist and in some areas may be more pressing, such as in terms of public funds and non-renewable resources. Policies that enhance productivity, that support equity, that ensure robust public finances, and that discourages overuse of natural resources will therefore still be important as will be the need to strengthen and enhance economic and political institutions.

97. A changing economic environment - and uncertainty around future developments - will however likely shift the way those policies should be pursued. The main conclusions from the analysis are:

33 See e.g. Frankel and Rose (1998), Calderón et al. (2003) and Dées and Zorell (2011) for evidence on trade integration and business cycle synchronisation. 


\section{Supporting growth}

- Further global integration and the rising reliance on knowledge-based assets for growth will increase potential benefits from international coordination and cooperation on the provision of certain global public goods. Thus growth could be enhanced by international coordination on basic research, legislation on intellectual property rights and competition regulation and enforcement. Rising trade integration will also make international cooperation on taxation of greenhouse gas emissions and highly mobile tax bases (such as capital and intangibles) more important.

- $\quad$ Flexible product and labour markets will become even more important for growth, supporting a faster deployment and absorption of new technologies and methods, and lowering costs of structural adjustment (and probably also contributing to reduce potential impediments to growth for currently emerging economies). In addition they may improve the incentives for work-related migration contributing to diminish the ageing shock in individual countries. Such policies will, however, have to be pursued in a way that cushions their potentially negative impact on equity.

- $\quad$ Private and social returns to education are likely to rise, creating potential for stronger growth and lower increases in inequality. Given tight fiscal conditions, public funds should be focused on pre-tertiary education (with high social returns) and life-long learning (where international labour mobility is low). Tertiary education should expand through higher reliance on tuition due to fiscal constraints and efficiency considerations. A tuition-based and loan-financed system is likely to be more efficient in recovering costs than a tax based system in a world with high mobility of skilled labour.

\section{Improving equity and the functioning of labour markets}

- Even though productivity growth will tend to increase incomes for most groups, earning inequalities are likely to continue to rise as long as technological progress remains skill-biased. Structural policies that can mitigate inequality in pre-tax earnings (such as employment protection) are often very costly in growth terms, and their ability to counteract skill-biased technological change is limited. This policy dilemma may be addressed by putting more emphasis on policies that enhance equality of opportunities (e.g. in education).

- It may be the case that the pace of structural change will slow in OECD economies over the coming decades, as increases in trade intensity and the pace of productivity growth will be slower than in the past. Emerging economies will at least initially face a much higher pace of structural change, reflecting inter alia the transition from high dependence on agriculture. The flexibility of the workforce will however decline in both regions, reflecting ageing, longer working lives and rapidly evolving skill requirements. Thus, while the overall need to support restructuring with active labour market policies may not increase (at least in the OECD), the composition of such policies should change to reflect the ageing workforce, with an added emphasis on training and lowering reservation wages.

\section{Addressing rising climate change costs}

- Economic costs of climate change are projected to already be significant by 2060. Given the lag between policy action and effects on climate, and in particular the risk of locking-in emission intensive infrastructure, action should be front-loaded. An appropriate pricing of carbon emissions is crucial to discourage emissions, but requires international coordinated efforts.

- Further global trade and investment integration will make production-based taxes on emissionintensive activities less efficient, especially in the absence of a binding multilateral agreement on emissions reduction. Although alternative mechanisms such as border carbon adjustments can appear an attractive solution, the practical difficulties and potential costs of such measures should provide a strong incentive to find a globally coordinated solution. 
- Trade and (long-term) investment integration can improve risk-sharing of hard-to-predict climate damages.

Fiscal and macroeconomic strategies

- Fiscal challenges and risks over the coming fifty years are large. On top of needed consolidation, structural reforms to save on costs (e.g. of education) and increase the resilience of public finances (e.g. pension systems) to shocks (e.g. from migration) are needed.

- $\quad$ Further global integration combined with an increasing reliance on mobile intangible inputs in growth will raise the social costs of taxing capital and other mobile factors for a single country. A shift of taxation towards more immobile tax bases would therefore be warranted. Global coordination on taxation would support fiscal positions and equity.

- With rising global integration, domestic shocks will increasingly be shared with trade partners. On average volatility may fall, lowering the need for stabilisation. At the same time, the stabilising properties of fiscal policies will diminish. Benefits from macroeconomic coordination are likely to rise.

- Increasing cross-border long-term investment integration would improve risk-sharing and lower risks of sudden reversals due to current account imbalances. 


\section{BIBLIOGRAPHY}

Aghion P, Griffith R. (2005) Competition and Growth. Zeuthen Lectures, MIT Press.

Aghion, P., N. Bloom, R. Blundell, R. Griffith and P. Howitt (2005), "Competition and innovation: An inverted-U relationship”, Quarterly Journal of Economics 120, No. 2, pp. 701-728.

Ahrend, R. and A. Goujard (2012), "International Capital Mobility and Financial Fragility - Part 3. How Do Structural Policies Affect Financial Crisis Risk?: Evidence from Past Crises Across OECD and Emerging Economies", OECD Economics Department Working Papers, No. 966, OECD Publishing. http://dx.doi.org/10.1787/5k97fmtj5vtk-en

Andersen, Torben (2008), “The Scandinavian Model: Prospects and Challenges”, International Tax and Public Finance, Special Issue, No.15, pp. 45-66.

Andrews, D. and A. de Serres (2012), "Intangible Assets, Resource Allocation and Growth", OECD Economics Department Working Papers, No. 989, OECD, Paris.

Andrews, D. and C. Criscuolo (2013), "Knowledge-based capital, innovation and resource allocation”, OECD Economics Department Working Papers, No. 1046, OECD, Paris.

Andrews, D. and B. Westmore (2014), "Managerial capital and business R\&D as enablers of productivity convergence”, OECD Economics Departement Working Papers, No. 1137, OECD, Paris.

Arnold, Jens \& Bert Brys \& Christopher Heady \& Åsa Johansson \& Cyrille Schwellnus \& Laura Vartia (2011), "Tax Policy for Economic Recovery and Growth", Economic Journal, Royal Economic Society, Vol. 121(550), pp F59-F80, February.

Autor, D., L. Katz, and A. Krueger (1998), “Computing Inequality: Have Computers Changed the Labor Market?”, Quarterly Journal of Economics, CXIII, pp. 1169-1214.

Bloom, N. and J. Van Reenen (2010), "Why Do Management Practices Differ across Firms and Countries?", Journal of Economic Perspectives, No. 24(1), pp. 203-224.

Bloom, N., R. Sadun and J. Van Reenen (2012), “Americans Do IT Better: US Multinationals and the Productivity Miracle", American Economic Review 102(1): 167-201.

Bouis, R., R. Duval and F. Murtin (2011), "The Policy and Institutional Drivers of Economic Growth Across OECD and Non-OECD Economies: New Evidence from Growth Regressions", OECD EConomics Department Working Papers, No. 843, OECD Publishing. http://dx.doi.org/10.1787/5kghwnhxwkhj-en

Braconier, H. (2014), "Determinants of Tertiary Graduations", OECD Economics Department Working Papers, No. 1138.

Braconier, H. and J. Ruiz Valenzuela (2014), "Scenarios for Earning Inequalities in OECD Countries", OECD Economics Department Working Papers, No. 1139.

Braconier, H. and R. Dellink (2014), "Consequences of Climate Change Damages for Economic Growth - A Dynamic Quantitative Assessment”, OECD Economics Department Working Papers, No. 1135.

Brynjolfsson, E, and A. McAfee (2011), "Race Against The Machine: How the Digital Revolution is Accelerating Innovation, Driving Productivity, and Irreversibly Transforming Employment and the Economy", Digital Frontier Press. 
Brynjolfsson, E., A. Renshaw and V. Marshall Alstyne (1997), "The Matrix of Change: A Tool for Business Process Reengineering", Sloan Management Review, pp. 37-54.

Burniaux, J. and J. Chateau (2008), "An Overview of the OECD ENV-Linkages Model", OECD EConomiCS Department Working Papers, No. 653, OECD Publishing. http://dx.doi.org/10.1787/230123880460

Causa, O., A. De Serres and N. Ruiz (2014),"Structural Reforms and Income Distribution”, OECD EConomicS Department Policy Papers, forthcoming.

Causa, O., S. Dantan and Å. Johansson (2009), "Intergenerational Social Mobility in European OECD Countries", OECD Economics Department Working Papers, No. 709, OECD Publishing. doi: $10.1787 / 223043801483$

Chateau, J., R. Dellink, E. Lanzi and B. Magné (2014), “An overview of the ENV-Linkages model - version 3", OECD Environment Working Papers, No. 43.

Cockburn, I.M., M.J. MacGarvie and E. Muller (2009), "Patent Thickets, Licensing and Innovative Performance", ZEW Discussion Paper, No. 08-101.

Cosbey, A (2008), "Border Carbon Adjustment”, International Institute for Sustainable Development, Canada

Cournède, B., A. Goujard and Á. Pina (2013), "How to Achieve Growth- and Equity-friendly Fiscal Consolidation?: A Proposed Methodology for Instrument Choice with an Illustrative Application to OECD Countries", OECD Economics Department Working Papers, No. 1088, OECD Publishing. doi: $10.1787 / 5 \mathrm{k} 407$ lwvzkkh-en

Cournède, B. and O. Denk (2014) "Finance and economic growth in OECD and G20 countries", OECD Economics Department Working Papers, forthcoming.

De Backer, K. and S. Miroudot (2013), "Mapping Global Value Chains”, OECD Trade Policy Papers, No. 159, OECD Publishing. http://dx.doi.org/10.1787/5k3v1trgnbr4-en

de la Maisonneuve, C. and J. Oliveira Martins (2013), "A Projection Method for Public Health and Long-Term Care Expenditures", OECD Economics Department Working Papers, No. 1048, OECD Publishing. doi: $10.1787 / 5 \mathrm{k} 44 \mathrm{v} 53 \mathrm{w} 5 \mathrm{w} 47-\mathrm{en}$

De Serres, A., F. Murtin and C. De La Maisonneuve (2012), "Policies to Facilitate the Return to Work", Comparative Economic Studies, Vol. 54:1, pp. 5-42.

Di Giovanni, J. and A. A. Levchenko (2009), "Putting the Parts Together: Trade, Vertical Linkages, and Business Cycle Co-movement," IMF Working Paper, 09/181.

Dynan, K., Skinner, J. and S. Zeldes (2004), “Do the Rich Save More?), Journal of Political Economy, Vol. 112, No. 2.

Fall, F., D. Bloch, P. Hoeller, J. Pareliussen and M. Pisu (2014), "Vulnerability of Social Institutions", OECD Economics Department Working Papers, forthcoming.

Fernald, J. and C.I Jones (2014), “The Future of US Economic Growth”, NBER Working Papers, No. 19830, National Bureau of Economic Research. 
Fournier, J. and I. Koske (2012), "Less Income Inequality and More Growth - Are they Compatible? Part 7. The Drivers of Labour Earnings Inequality - An Analysis Based on Conditional and Unconditional Quantile Regressions", OECD Economics Department Working Papers, No. 930, OECD Publishing. doi: $10.1787 / 5 \mathrm{k} 9 \mathrm{~h} 28 \mathrm{~s} 354 \mathrm{hg}$-en

Goos, M. , A. Manning and A. Salomons (2009), "Job Polarization in Europe", American Economic Review paper and proceedings, Vol. 99: 2, pp. 58-63.

Goos, M., A Manning and A. Salomons (2011), "Explaining job polarization: the roles of technology, offshoring and institutions", Centre for Economic Studies: Katholieke Universiteit Leuven, Discussion Paper, 11.34.

Griffith, R., S. Redding and J. Van Reenan (2004), "Mapping the Two Faces of R\&D: Productivity Growth in a Panel of OECD Industries", The Review of Economics and Statistics, 86(4), pp. 883-895.

Hatton, T.J., and J.G. Williamson (2002), "What Fundamentals Drive World Migration?" NBER Paper, No. 9159.

Hoeller, P., I. Joumard, M. Pisu and D. Bloch (2012), "Less Income Inequality and More Growth - Are They Compatible? Part 1. Mapping Income Inequality Across the OECD", OECD Economics Department Working Papers, No. 924, OECD Publishing. doi: 10.1787/5k9h297wxbnr-en

IEA (2013), World Energy Outlook 2013, OECD Publishing, Paris.

IMF - International Monetary Fund (2007), "Globalization and Inequality”, World Economic Outlook, IMF, Washington, pp.31-65, October.

Johansson, Å. and E. Olaberría (2014), "Long-term Patterns of Specialisation and Trade”, OECD EConomicS Department Working Paper, No. 1136.

Joumard, I., M. Pisu and D. Bloch (2012), "Less Income Inequality and More Growth - Are They Compatible? Part 3. Income Redistribution via Taxes and Transfers Across OECD Countries", OECD EConomics Department Working Papers, No. 926, OECD Publishing. http://dx.doi.org/10.1787/5k9h296b1zjf-en

Kozluk, T., V. Zipperer, S. Albrizio and E. Botta (2014), "Environmental Policies and Productivity Growth Insights from New Cross country Measures of Environmental Policies", OECD Economics Department Working Papers, forthcoming.

Kumhof, H. and R. Rancière (2010), "Inequality, Leverage and Crises”, IMF Working Paper, 10/268.

Levchenko, A. and J. Zhang (2013), “The Global Labour Market Impact of Emerging Markets: a Quantitative Assessment", IMF Economic Review 2013/8.

Lindbeck, Assar, and Mats Persson. 2003. "The Gains from Pension Reform ." Journal of Economic Literature, 41(1): 74-112.

Miroudot, S., D. Rouzet and F. Spinelli (2013), “Trade Policy Implications of Global Value Chains", OECD Trade Policy Papers, No. 161, OECD Publishing. http://dx.doi.org/10.1787/5k3tpt2t0zs1-en

Myles J., Q. Jill.(2002). “Political Theories of the Welfare State.” Social Service Review, No. 76: 34-57.

OECD (1994), Manufacturing Performance: A Scoreboard of Indicators, Paris.

OECD (2009), The Economics of Climate Change Mitigation: Policies and Options for Global Action beyond 2012, OECD Publishing. doi: 10.1787/9789264073616-en

OECD (2011a), OECD Economic Outlook, Vol. 2011/1, OECD Publishing. 
OECD (2011b), “Divided We Stand: Why Inequality Keeps Rising”, OECD publishing. http://dx.doi.org/10.1787/9/9789264119536-en

OECD (2013a), OECD Economic Outlook, Vol. 2013/1, OECD Publishing.

OECD (2013b), OECD Economic Outlook, Vol. 2013/2, OECD Publishing.

OECD (2013c), "Raising the Returns to Innovation: Structural Policies for a Knowledge-based Economy", OECD Economics Department Policy Notes, No. 17 May 2013.

OECD (2013d), Economic Policy Reforms: Going for Growth, OECD Publishing.

OECD (2013e), Education at a Glance 2013: OECD indicators, OECD Publishing.

OECD (2013f), Interconnected Economies: Benefiting From Global Value Chains3

OECD (2013g), OECD Skills Outlook 2013: First results from the survey of adult skills, OECD publishing.

OECD (2013h), Implications of Globalisation for Competition Policy: The need for International Cooperation in Merger and Cartel Enforcement, Secretariat Note.

OECD (2013i), Pensions at a Glance 2013: OECD and G20 Indicators, OECD Publishing. doi: 10.1787/pension_glance-2013-en

OECD (2013j), Inventory of Estimated Budgetary Support and Tax Expenditures for Fossil Fuels - 2013, OECD Publishing, Paris.

OECD (2013k), Supporting Investment in Knowledge Capital, Growth and Innovation, OECD Publishing. http://dx.doi.org/10.1787/9789264193307-enOECD (2014a), OECD Economic Outlook, No. 95, Vol. 2014/1, OECD Publishing.

OECD (2014), OECD Economic Outlook 95, Vol. 2014/1, Chapter 4, OECD Publishing.

OECD (2014), OECD Economic Outlook, Vol. 2014/1, OECD Publishing.

Ollivaud, P. and C. Schwellnus (2013), "The Post-crisis Narrowing of International Imbalances: Cyclical or Durable?", OECD Economics Department Working Papers, No. 1062, OECD Publishing. doi: $10.1787 / 5 \mathrm{k} 44 \mathrm{t} 7 \mathrm{j} 9 \mathrm{sdtc}-\mathrm{en}$

Piketty, T. and G. Zucman (2013), “Capital is Back: Wealth-Income Ratios in Rich Countries 1700-2010”, New Approaches to Economic Challenges: Research Seminar by Thomas Piketty, OECD.

Pozzi, A. and F. Schivardi (2012), “Demand or productivity: What determines firm growth?”, EIEF Working Paper Series, Einaudi Institute for Economics and Finance (EIEF).

Rajan, R. (2010), "Fault Lines: How Hidden Fractures Still Threaten the World Economy", Princeton: Princeton University Press.

Rivera-Batiz, L. and P. Romer (1991), "Economic Integration and Endogenous Growth”, Quarterly Journal of Economics, pp. 531-555.

Saint-Paul, G. (1997), “Is Labour Rigidity Harming Europe's Competitiveness? The Effect of Job Protection on the Pattern of Trade and Welfare", European Economic Review, Vol. 41, pp. 499-506.

Saint-Paul, G. (2002), "Employment Protection, International Specialization, and Innovation", European Economic Review, Vol. 46, pp. 375-395. 
Shapiro, C. (2001), "Navigating the Patent Thicket: Cross-licenses, Patent Pools, and Standard-Setting", in: Jaffe, A., Lerner, J. and Stern, S. (eds.), Innovation Policy and the Economy, Vol. 1. MIT Press for the National Bureau of Economic Research.

Skeldon, R (2008), "Migration and Development”, United Nations Expert Group Meeting on International Migration and Development in Asia and The Pacific. September 2008.

Sutherland, D. and P. Hoeller (2012), "Debt and Macroeconomic Stability: An Overview of the Literature and Some Empirics”, OECD Economics Department Working Papers, No. 1006.

UK IPO (2011), "Patent Thickets: An Overview”. http://www.ipo.gov.uk/informatic-thickets.pdf

Ventura, J. (2005), “A Global View of Growth”, NBER Working Paper, No. 11296.

Westmore, B (2013), "Innovation and Growth: Considerations for Public Policy", Review of Economics and Institutions, Vol. 4, no. 3, p 50.

Westmore, B. (2014) “The Influence of Relative Wage Differentials on International Migration", OECD Economics Department Working Papers, No. 1140.

Winston, G. (1999), "Subsidies, Hierarchy and Peers: The Awkward Economics of Higher Education", The Journal of Economic Perspectives, Vol 13, pp 13-36. 